'

Analysis of the Monitoring Network at the Salmon, Mississippi, Site

August 2013

Approved for public release; further dissemination unlimited

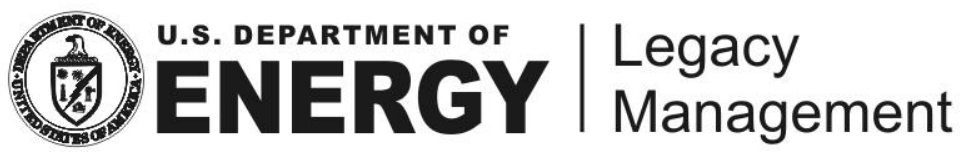


Available for sale to the public from:

U.S. Department of Commerce

National Technical Information Service

5301 Shawnee Road

Alexandria, VA 22312

Telephone: 800.553 .6847

Fax: 703.605.6900

E-mail: orders@ntis.gov

Online Ordering: http://www.ntis.gov/help/ordermethods.aspx

Available electronically at http://www.osti.gov/bridge

Available for a processing fee to U.S. Department of Energy and its contractors, in paper, from:

\author{
U.S. Department of Energy \\ Office of Scientific and Technical Information \\ P.O. Box 62 \\ Oak Ridge, TN 37831-0062 \\ Phone: 865.576 .8401 \\ Fax: 865.576.5728 \\ Email: reports@adonis.osti.gov
}

Reference herein to any specific commercial product, process, or service by trade name, trademark, manufacturer, or otherwise, does not necessarily constitute or imply its endorsement, recommendation, or favoring by the United States Government or any agency thereof or its contractors or subcontractors. 


\section{Analysis of the Monitoring Network at the Salmon, Mississippi, Site}

August 2013

Approved for public release; further dissemination unlimited 
This page intentionally left blank 


\section{Contents}

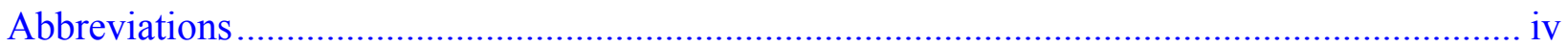

Executive Summary .................................................................................................... vii

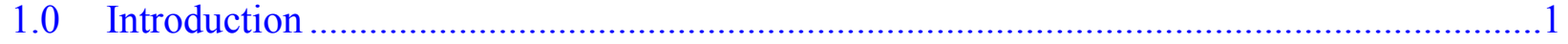

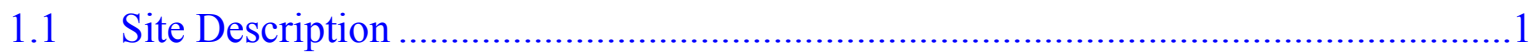

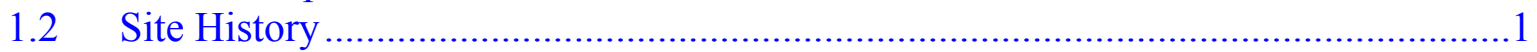

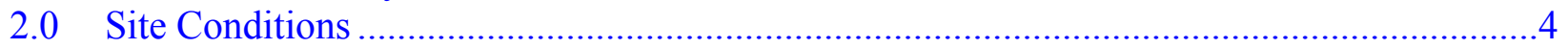

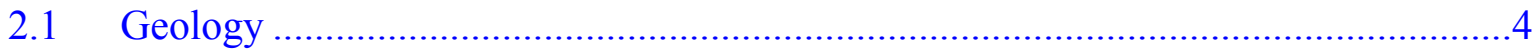

2.1.1 Citronelle Formation, Terrace Deposits, and Alluvium................................6

2.1.2 Hattiesburg Formation ............................................................................

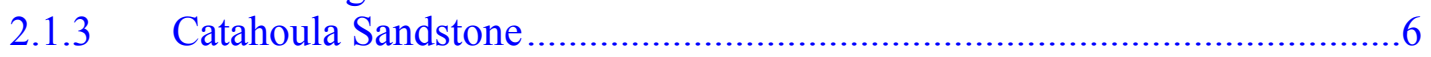

2.1.4 Vicksburg Group............................................................................

2.1.5 Cook Mountain Limestone ……………...............................................

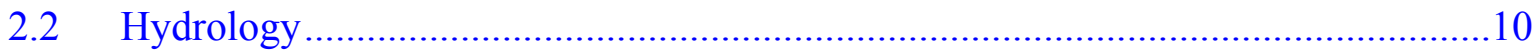

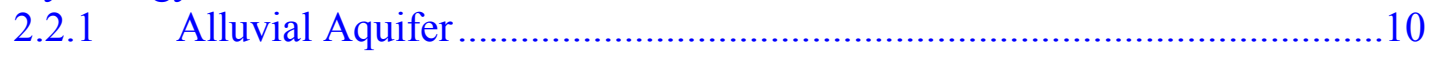

2.2.2 Citronelle Aquifer ...........................................................................10

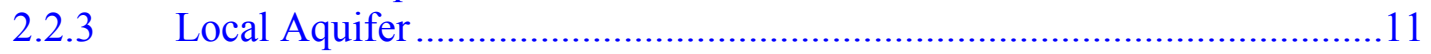

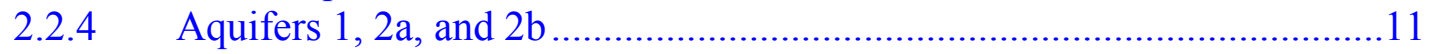

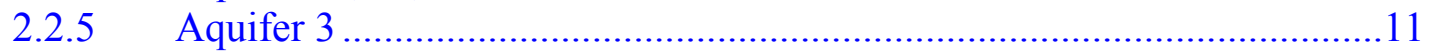

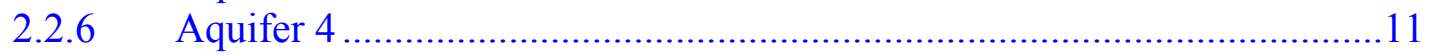

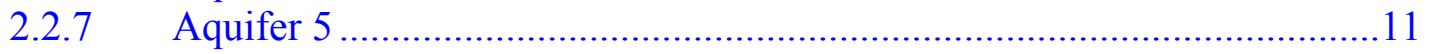

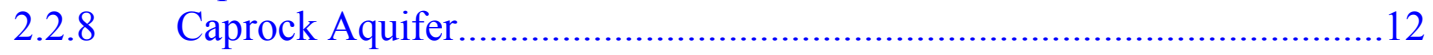

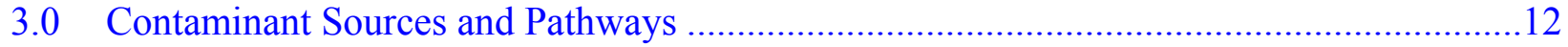

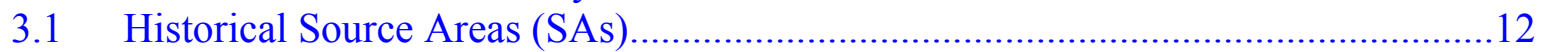

3.1.1 Source Area 1: Surface Ground Zero...................................................12

3.1.2 Source Area 2: Northern Disposal Area .................................................17

3.1.3 Source Area 3: Southern Storage Area ………………............................19

3.1.4 Source Area 4: Western Disposal Area …………....................................21

3.1.5 Source Area 5: Injection Well Area...........................................................22

3.1.6 Source Area 6: Helicopter Pad and Storage Area .......................................23

3.2 Contaminant Pathways ……………………………………………………....23

3.2.1 Current Contaminants ...........................................................................24

3.2.2 Potential Contamination from Aquifer 5 ……………………………......37

3.2.3 Potential Contamination from the Shot Cavity ...........................................37

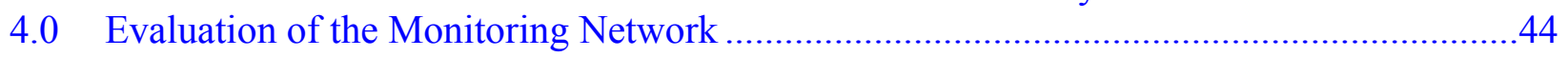

$4.1 \quad$ Surface Water Locations ...................................................................................44

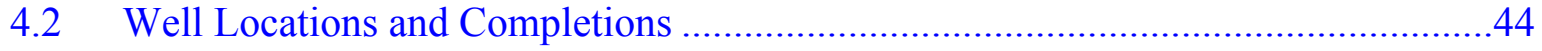

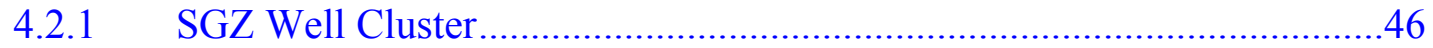

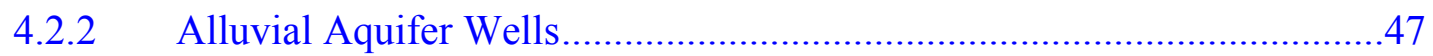

4.2.3 Local Aquifer Wells...........................................................................4

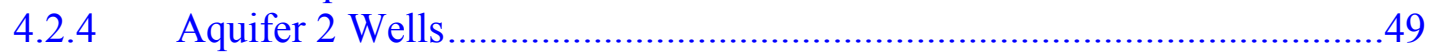

4.2.5 Aquifer 3 Wells.................................................................................50

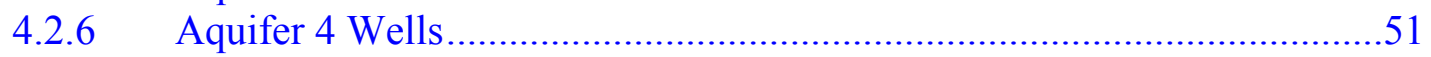

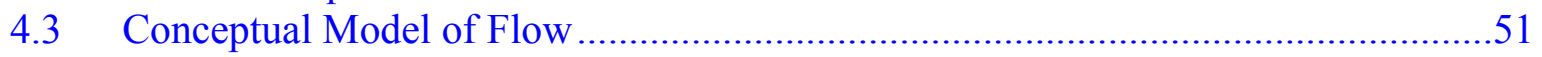

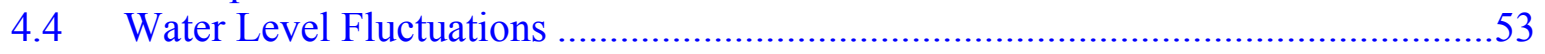

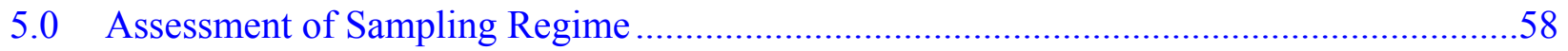

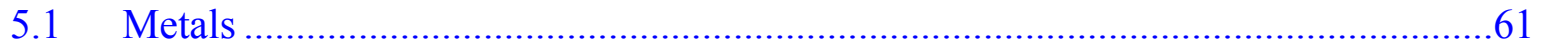




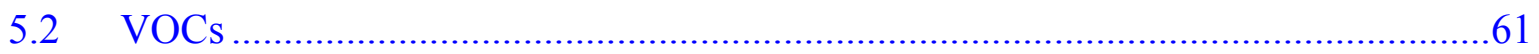

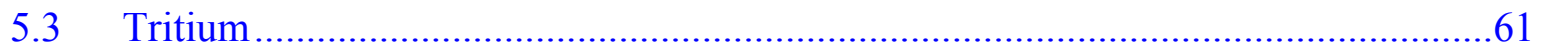

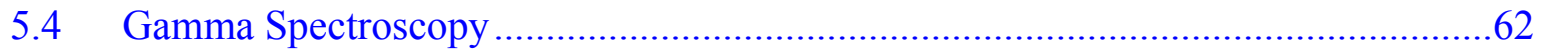

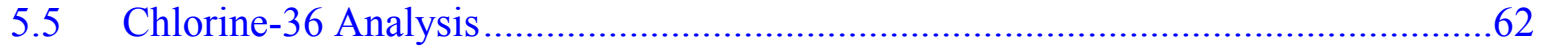

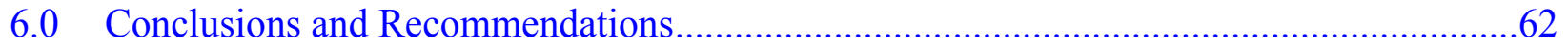

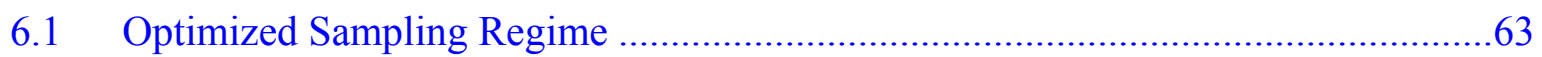

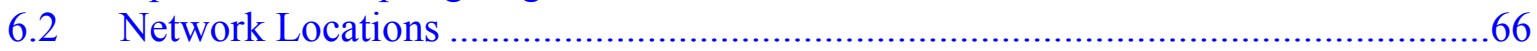

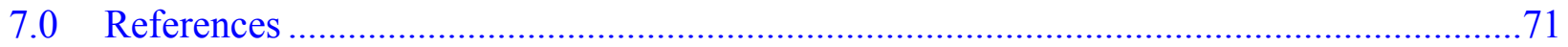

\section{Figures}

Figure 1. Salmon Site Location......................................................................................... 2

Figure 2. Locations Used to Generate Stratigraphic Cross Sections in RockWorks .................... 3

Figure 3. Stratigraphic Logs for Wells HT-1, E-1, E-14, E-4, and HT-2 ……......................... 5

Figure 4. Zoomed-In Cross Section from Well SA1-7-H to Well HT-1 …………….................... 7

Figure 5. Zoomed-In Cross Section from Well E-1 to Well SA1-11-3 ……............................... 8

Figure 6. Cross Section from Well HT-2 to Well MTH-3 ................................................... 9

Figure 7. Monitoring Network, Historical Source Areas, and CPT Locations ........................... 13

Figure 8. Current Arsenic Concentrations at the Salmon Site ……………………………….... 27

Figure 9. Current Barium Concentrations at the Salmon Site .................................................. 28

Figure 10. Current Chromium Concentrations at the Salmon Site................................................ 29

Figure 11. Current Lead Concentrations at the Salmon Site.......................................................... 30

Figure 12. Current Zinc Concentrations at the Salmon Site.......................................................... 31

Figure 13. Current Trichloroethene Concentrations at the Salmon Site ....................................... 32

Figure 14. Current cis-1,2-Dichloroethene Concentrations at the Salmon Site ............................. 33

Figure 15. Current trans-1,2-Dichloroethene Concentrations at the Salmon Site........................ 34

Figure 16. Current Vinyl Chloride Concentrations at the Salmon Site...................................... 35

Figure 17. Current Tritium Concentrations at the Salmon Site...................................................... 36

Figure 18. Aquifer 4 and Five Wells and Stratigraphic Section .............................................. 37

Figure 19. Cross-Sectional Depiction of the Shot Cavity ........................................................... 39

Figure 20. Location of the Shot Cavity ..................................................................................... 40

Figure 21. Conceptual Model of the Relationship of the Dome, Shot Cavity, and SGZ

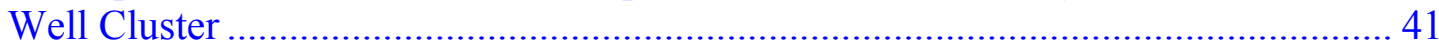

Figure 22. Screened Intervals and Water Levels of SGZ Wells ................................................. 46

Figure 23. Screened Intervals and Water Levels in the Alluvial Aquifer................................... 47

Figure 24. Screened Intervals and Water Levels in the Local Aquifer......................................... 48

Figure 25. Screened Intervals and Water Levels of Aquifer 2 Wells ............................................ 49

Figure 26. Screened Intervals and Water Levels in Aquifer 3 .................................................... 50

Figure 27. Screened Intervals and Water Levels in Aquifer 4 ..................................................... 51

Figure 28. Conceptual Model of Flow Relative to Half Moon Creek and SGZ ………................ 52

Figure 29. Local Aquifer Water Levels ...................................................................................... 54

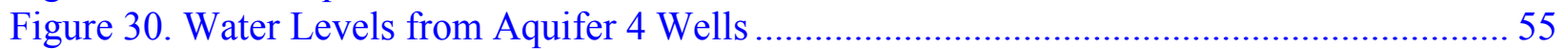

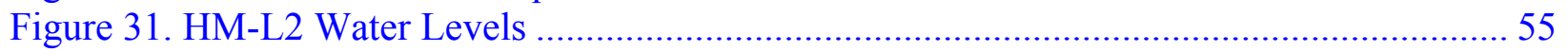

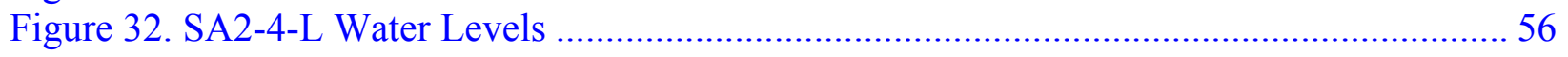

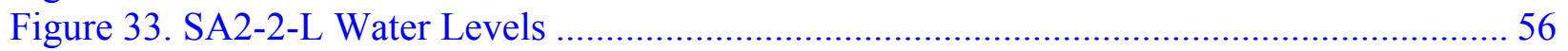

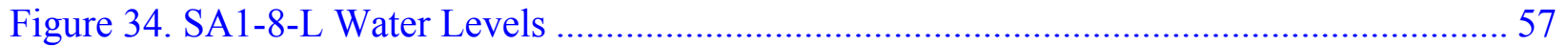

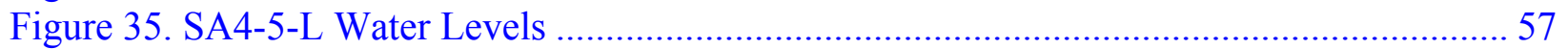

Figure 36. Potential Locations for New Wells............................................................................. 69 


\section{Tables}

Table 1. SA1 CPT Sampling Results ................................................................................. 16

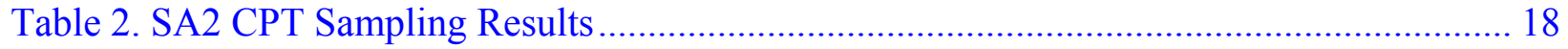

Table 3. SA3 CPT Sampling Results ................................................................................ 21

Table 4. SA4 CPT Sampling Results ................................................................................. 22

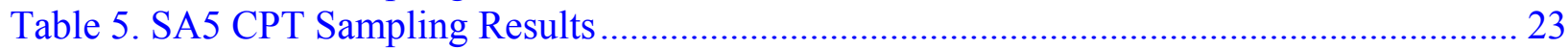

Table 6. Candidate Radionuclides for Inclusion into Source-Term Inventory .......................... 43

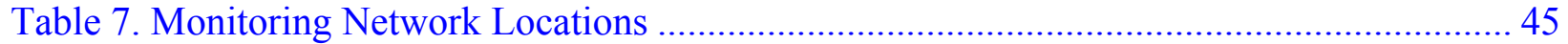

Table 8. Status of Pressure Transducers for Recording Water Levels at Wells ........................ 58

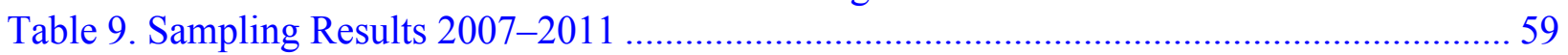

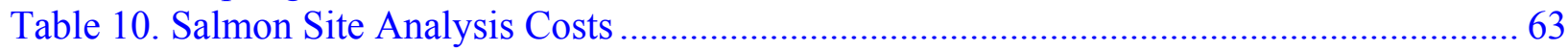

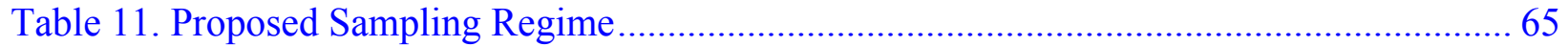

Table 12. Proposed Locations of New Wells at the Salmon Site ........................................... 67

\section{Appendix}

Appendix A Select 1993 CPT Results 


\section{Abbreviations}

AEC U.S. Atomic Energy Commission

Ag silver

As arsenic

$\mathrm{Ba} \quad$ barium

Be beryllium

Cd cadmium

CPT cone penetrometer testing

$\mathrm{Cr} \quad$ chromium

DCE dichloroethene

DNAPL dense nonaqueous-phase liquid

DOE U.S. Department of Energy

EPA U.S. Environmental Protection Agency

$\mathrm{ft} \quad$ feet

$\mathrm{Hg}$ mercury

hr hours

ICP inductively coupled plasma emission spectrometer

ICP-MS inductively coupled plasma-mass spectrometer

LM Office of Legacy Management

LTHMP Long-Term Hydrologic Monitoring Program

MCL maximum contaminant level

$\mu \mathrm{g} / \mathrm{L} \quad$ micrograms per liter

$\mathrm{mg} / \mathrm{L} \quad$ milligrams per liter

$\mathrm{Ni} \quad$ nickel

$\mathrm{Pb} \quad$ lead

PCE perchloroethene

$\mathrm{pCi} / \mathrm{L} \quad$ picocuries per liter

REECo Reynolds Electrical and Engineering Company Inc.

RI/FS Remedial Investigation/Feasibility Study

SA source area

$\mathrm{Sb}$ antimony

Se selenium

SGZ surface ground zero 


\section{TCE trichloroethene \\ USGS U.S. Geological Survey \\ VOC volatile organic compound \\ Zn zinc}


This page intentionally left blank 


\section{Executive Summary}

The Salmon site in southern Mississippi was the location of two underground nuclear tests and two methane-oxygen gas explosion tests conducted in the Tatum Salt Dome at a depth of 2,715 feet below ground surface. The U.S. Atomic Energy Commission (a predecessor agency of the U.S. Department of Energy [DOE]) and the U.S. Department of Defense jointly conducted the tests between 1964 and 1970. The testing operations resulted in surface contamination at multiple locations on the site and contamination of shallow aquifers. No radionuclides from the nuclear tests were released to the surface or to groundwater, although radionuclide-contaminated drill cuttings were brought to the surface during re-entry drilling. Drilling operations generated the largest single volume of waste materials, including radionuclide-contaminated drill cuttings and drilling fluids. Nonradioactive wastes were also generated as part of the testing operations.

Site cleanup and decommissioning began in 1971 and officially ended in 1972. DOE conducted additional site characterization between 1992 and 1999. The historical investigations have provided a reasonable understanding of current surface and shallow subsurface conditions at the site, although some additional investigation is desirable. For example, additional hydrologic data would improve confidence in assigning groundwater gradients and flow directions in the aquifers.

The U.S. Environmental Protection Agency monitored groundwater at the site as part of its Long-Term Hydrologic Monitoring Program from 1972 through 2007, when DOE's Office of Legacy Management (LM) assumed responsibility for site monitoring. The current monitoring network consists of 28 monitoring wells and 11 surface water locations. Multiple aquifers which underlie the site are monitored. The current analyte list includes metals, radionuclides, and volatile organic compounds (VOCs).

Analysis of the monitoring program presented in this report includes recommendations for changes in the analyte list, monitoring locations, and sampling frequency to provide a more focused data set for long-term monitoring at the site.

Metals analysis has historically consisted of a suite of 12 analytes. It is recommended that the list be reduced to four - arsenic, barium, chromium, and lead - and that analysis for these four be added to two additional wells. All other metals have either been undetected or have been present at concentrations well below established standards.

It is also recommended that analysis of VOCs be expanded to include wells in the Local Aquifer and select surface locations for at least one sampling event. The Local Aquifer underlies the Alluvial Aquifer, and the distribution of trichloroethene and its degradation products is not fully understood.

Radionuclides are analyzed by gamma spectroscopy. Isotopes of americium, cesium, and uranium currently have detection limits that might not be sufficiently low to allow early detection of contaminants potentially migrating from the shot cavity. Analysis for chlorine-36 will be conducted to see if it would be a suitable early indicator. Chlorine-36 is more mobile and has a longer half-life than the radionuclides currently analyzed by gamma spectroscopy. It is also recommended that gamma spectroscopy analysis be reduced to eight wells and no surface 
locations. The eight wells recommended are the ones most likely to first detect any migration from the shot cavity or the injection site.

Six additional wells (four in the Local Aquifer and two in the Alluvial Aquifer) are recommended to be installed to better determine flow directions in the Local Aquifer and interactions between the Local and Alluvial Aquifers. Two wells north of surface ground zero (SGZ) on either side of Half Moon Creek would help determine flow directions in the Local Aquifer in relation to SGZ. An Alluvial Aquifer well will be paired with the Local Aquifer well on the east side of Half Moon Creek between the Source Area 2 wells and the creek. Two Local Aquifer wells south of SGZ near well SA3-4-H and well E7 would help define the extent of the Local Aquifer south of SGZ; historical well logs indicate that the Local Aquifer is discontinuous in this area. An Alluvial Aquifer well will be paired with the Local Aquifer well near well E7.

No changes are currently recommended for the surface water sampling locations. It is recommended that during annual sampling in 2013, the newer locations (i.e., locations that have been sampled only since 2008) be assessed for ease of access and for whether alternative locations are available that would provide the same information. The assessment might show it would be beneficial to adjust these sampling points. Another recommendation is to determine if the three locations in REECo Pit 5 could be reduced to one location or to a composite sample of the three locations. 


\subsection{Introduction}

This report provides an analysis of the monitoring network at the Salmon, Mississippi, Site and evaluates the effectiveness of the current monitoring network and the sampling regime. The existing U.S. Department of Energy (DOE) Office of Legacy Management (LM) site data were analyzed to identify possible gaps or excesses in the network and analyte list and to provide recommendations for an optimized monitoring network that obtains the needed information while remaining protective of human health and the environment.

Groundwater monitoring has been conducted at the Salmon site since it was decommissioned in 1972. LM has conducted groundwater and surface water monitoring at the site since 2007 . The current monitoring network consists of 28 monitoring wells and 11 surface water locations. The onsite wells are completed in multiple aquifers. Samples are collected annually and analyzed for multiple constituents. The constituents analyzed are radioactive isotopes (actinium-228, americium-241, antimony-125, cerium-144, cesium-134, cesium-137, cobalt-60, europium-152, europium-154, europium-155, lead-212, potassium-40, promethium-144, promethium-146, ruthenium-106, thorium-234, tritium, uranium-235, uranium-238, and yttrium-88); metals (antimony [Sb], arsenic [As], barium [Ba], beryllium [Be], cadmium [Cd], chromium [Cr], lead $[\mathrm{Pb}]$, nickel [Ni], selenium [Se], silver [Ag], and zinc [Zn]); and a large suite of volatile organic compounds (VOCs), including trichloroethene (TCE), cis- and trans-1,2-dichloroethene (DCE), and vinyl chloride.

\subsection{Site Description}

The Salmon site, formerly known as the Tatum Salt Dome Test Site, is a 1,470-acre tract of land in Lamar County, Mississippi, 21 miles southwest of Hattiesburg and about 10 miles west of Purvis (Figure 1). The site is in a forested region known as the long-leaf pine belt of the Gulf Coastal Plain and overlies the Tatum Salt Dome. Elevations in the area range from about 240 to 350 feet (ft) above sea level. Grantham and Half Moon Creeks, which flow into the site from the east and south respectively, join and flow northward through the site. Hickory Hollow Creek flows from the west and joins Half Moon Creek south of the junction with Grantham Creek (Figure 2). Land around the Salmon site has residential, industrial, and commercial use. DOE transferred surface ownership of the site to the State of Mississippi in December 2010. The Mississippi Forestry Commission currently uses the site as a wildlife refuge and working demonstration forest. DOE is responsible for the monitoring wells, the monument at surface ground zero (SGZ), and the subsurface real estate, including any residual radioactive or other hazardous materials generated by DOE and predecessor agencies at the site.

\subsection{Site History}

The U.S. Atomic Energy Commission (AEC), which was a predecessor agency of DOE, and the U.S. Department of Defense conducted two underground nuclear tests - Salmon and Sterling — at the site under the designation of Project Dribble, part of a larger program known as the Vela Uniform program. Two gas explosive tests, designated Project Miracle Play, were also conducted at the site. The Salmon and Sterling tests were designed to evaluate seismic signals from detonations in a salt medium. The Salmon test took place on October 22, 1964, at a depth 


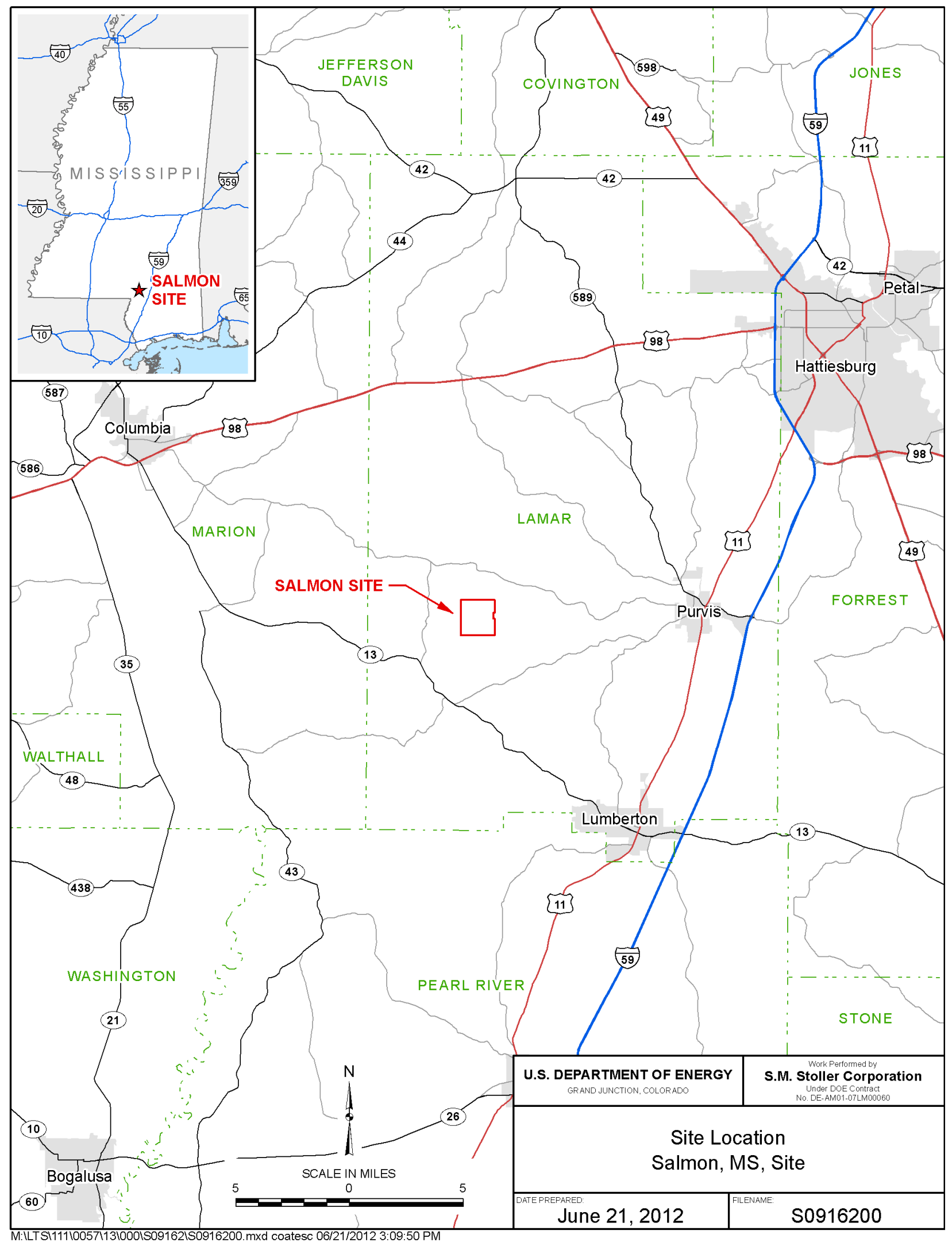

Figure 1. Salmon Site Location 


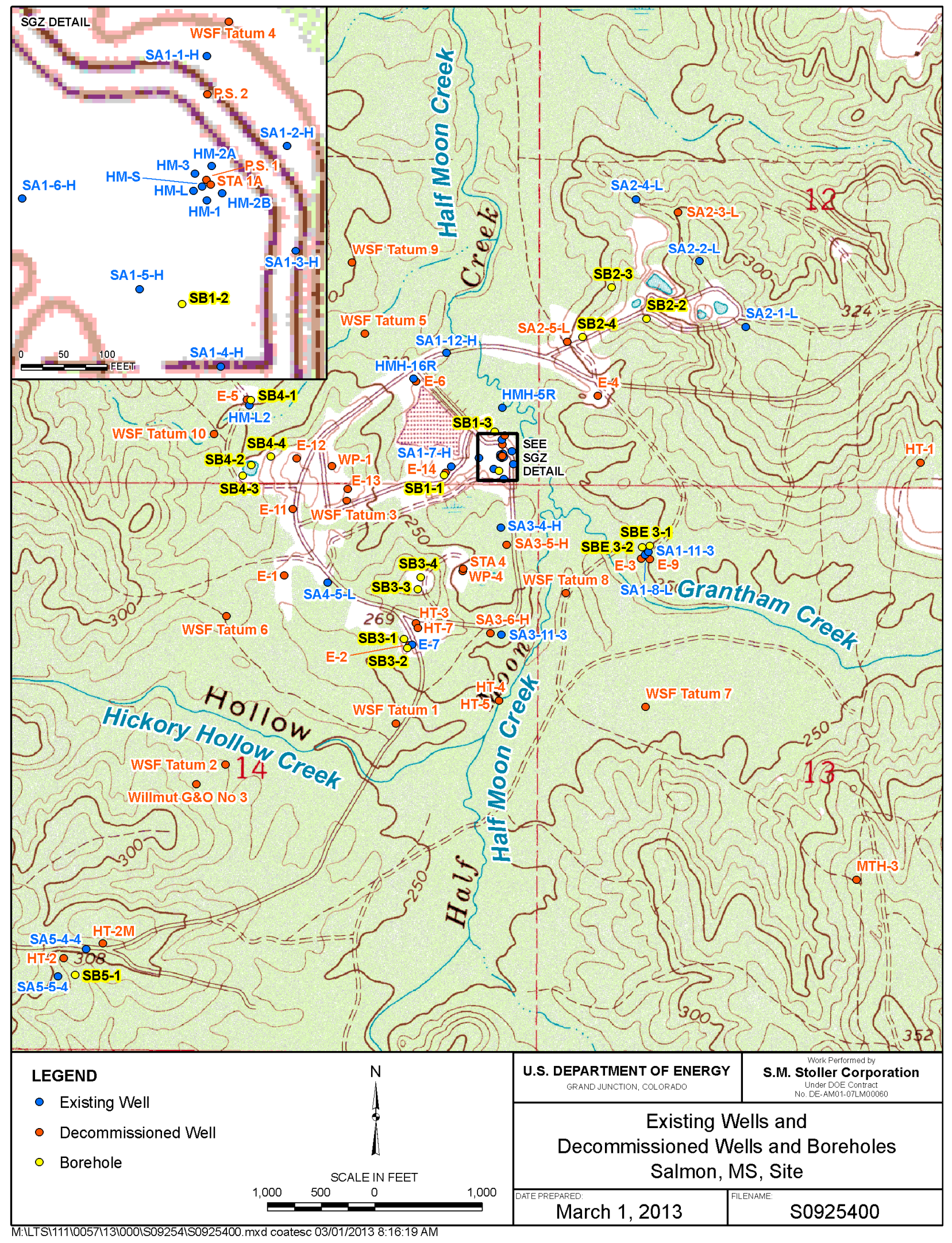

Figure 2. Locations Used to Generate Stratigraphic Cross Sections in RockWorks 
of 2,715 $\mathrm{ft}$ below ground surface, which is approximately 1,200 $\mathrm{ft}$ below the top of the salt dome. This 5.3-kiloton-yield test created an underground test cavity approximately $114 \mathrm{ft}$ in diameter at the depth of the detonation. The second, smaller test, Sterling, conducted on December 3, 1966, consisted of a 380-ton-yield nuclear device suspended in the cavity that was created by the Salmon test. Two methane-oxygen explosions were also conducted in the Salmon cavity-Diode Tube on February 2, 1969, and Humid Water on April 19, 1970. Each test had a yield of approximately 315 tons. The salt dome fully contained all of the tests, and no radionuclides were released to the surface during the tests. The test site was decommissioned in 1972.

The U.S. Environmental Protection Agency (EPA) Environmental Monitoring Systems Laboratory began the Long-Term Hydrologic Monitoring Program (LTHMP) in April 1972. EPA conducted the LTHMP until 2007, when LM assumed responsibility for monitoring.

\subsection{Site Conditions}

RockWorks software was used to get a better visual representation of the formations and aquifers present at the site. The stratigraphic data were obtained from (1) plugging records (DOE 1972), (2) the U.S. Geological Survey (USGS) southwest-northeast cross section through Tatum Dome, and (3) geophysical logs in historical site documents and USGS technical letters. Missing data were estimated based on well completions or extrapolated from nearby wells. The current monitoring network and select abandoned wells and boreholes (Figure 2) were used to supplement the site stratigraphic data and to generate representative cross sections. The cross sections combine both lithostratigraphic and hydrostratigraphic information. Aquifer zones (bright colors) and the lithology (earth colors) were entered into Rockworks as stratigraphic layers to simplify the site model and to generate the figures. Confining units within formations are not specifically identified, and are simply named by the formation they are in.

\subsection{Geology}

Tatum Dome is a salt dome within the Mississippi Interior Salt Basin. The dome consists of a salt core overlain by anhydrite and limestone cap rock. The salt core is roughly circular with a flat top at about 1,500 ft below ground surface. The salt consists of roughly 90 percent halite (sodium chloride) and 10 percent anhydrite (calcium sulfate). The anhydrite cap rock is 450 to $600 \mathrm{ft}$ thick and extends upward to about 1,000 ft below ground surface. The cap rock is overlain by the Catahoula Sandstone of Oligocene age; the Catahoula is 100 to $200 \mathrm{ft}$ thick and is overlain by the Pascagoula-Hattiesburg clays of Miocene age (Hattiesburg Formation), which crop out regionally in the lower stream valleys and also extend across the dome. The Hattiesburg Formation is 550 to $750 \mathrm{ft}$ thick. The surficial material at the Salmon site is the Citronelle Formation, terrace deposits, and alluvium of Pliocene-Pleistocene-recent age. They consist of gravel, sand, and silty clay about $150 \mathrm{ft}$ thick. The Citronelle crops out on the slopes and tops of the hills in the site area. The Cook Mountain limestone and the overlying Vicksburg Group are stratigraphic units below the Catahoula sandstone, and are both pierced by the dome. The Tatum Dome appears to have no topographic expression. The Hattiesburg Formation is slightly arched over the dome (Fenske and Humphrey 1980). The geologic units southwest of Tatum Dome (inferred from the lithologic descriptions for well HT-2) are 25 to $230 \mathrm{ft}$ deeper than the same units on the updip (northeast) side of the dome (well HT-1) (Figure 3). 


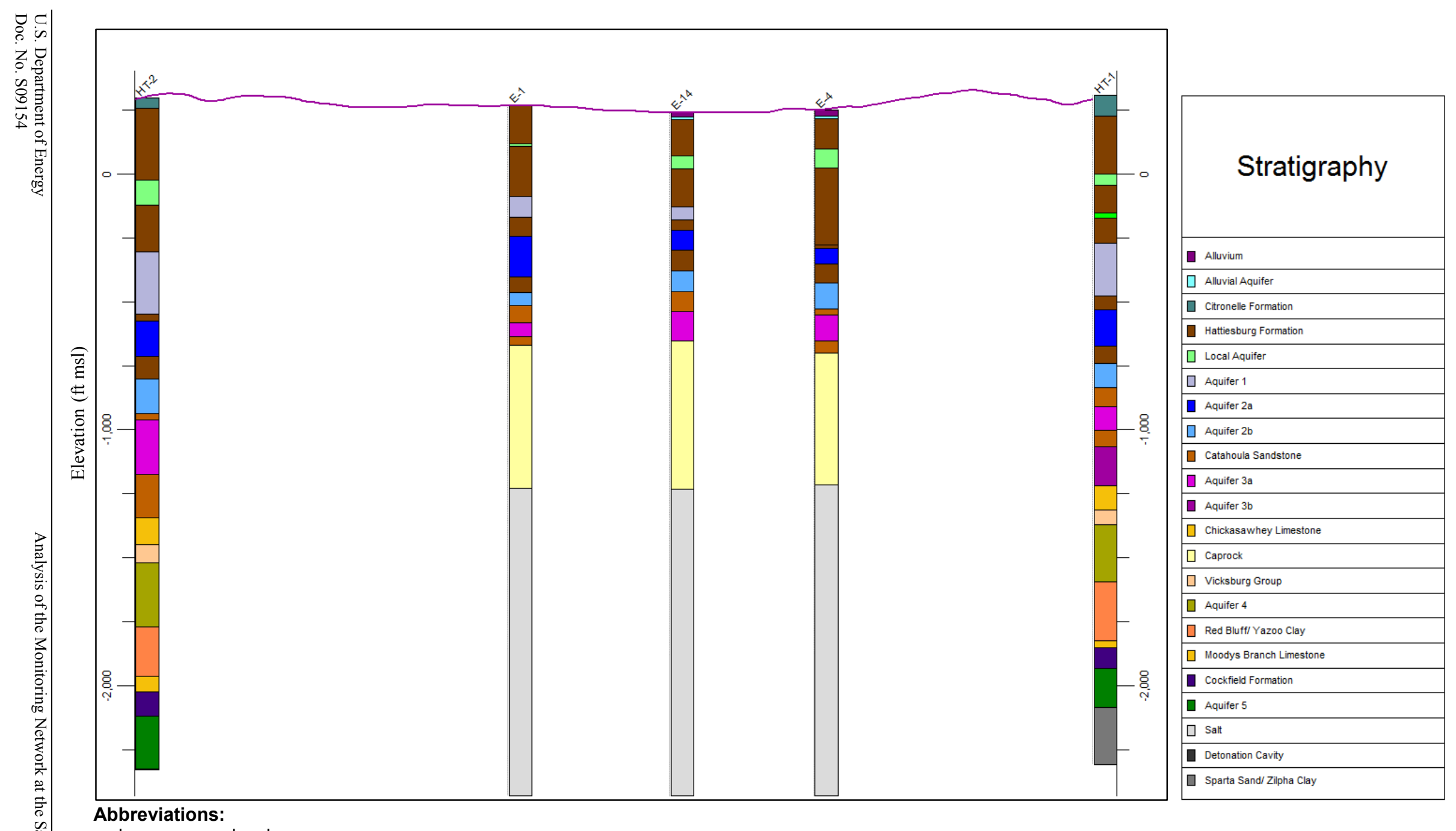

Figure 3. Stratigraphic Logs for Wells HT-1, E-1, E-14, E-4, and HT-2 


\subsubsection{Citronelle Formation, Terrace Deposits, and Alluvium}

The Citronelle Formation, terrace deposits, and alluvium form a surface veneer of sand and gravel over most of southern Mississippi. In the Salmon site area, the deposits range from 0 to $130 \mathrm{ft}$ in thickness, with the thicker sections located on the terraces and gentle slopes of the ridges. In a few places along some steep ridges and in deeper stream valleys where the streams have eroded down to the Miocene clays, these surficial deposits are absent. This permeable veneer of sand and gravel forms an extensive water-table aquifer overlying the Miocene deposits and is an excellent environment for ready recharge to the underlying aquifers (Harvey and Chaffin 1963). The Citronelle Aquifer occurs at the contact of the Pascagoula/Hattiesburg and Citronelle Formations. In the vicinity of the Salmon site, this aquifer is primarily a silty sand. The Citronelle Formation is about $80 \mathrm{ft}$ in maximum thickness and crops out on the slopes and tops of hills at the Salmon site above the $250 \mathrm{ft}$ contour (DOE 1999) (Figure 4).

\subsubsection{Hattiesburg Formation}

Pascagoula-Hattiesburg clays of Miocene age, referred to in this report as the Hattiesburg Formation, compose the majority of the stratigraphy above the Tatum Dome. The Hattiesburg Formation contains multiple sand beds separated by clay confining units. Lithology ranges from silty calcareous clay to fine sand to very coarse sand with some pebbles. These sand beds contain freshwater in the Local Aquifer and Aquifers 1, 2a, and 2b (Harvey and Chaffin 1963) (Figure 5). The Hattiesburg Formation is overlain by surficial deposits of recent alluvium in the stream valleys.

\subsubsection{Catahoula Sandstone}

The Catahoula Sandstone is present both over and adjacent to the dome and comprises material that ranges from silt to coarse sand and pebbles. The Catahoula Sandstone includes Aquifers 3a and $3 \mathrm{~b}$ and is separated from the underlying Vicksburg Group by relatively impermeable beds, possibly correlative with the Chickasawhay Limestone (Harvey and Chaffin 1963). The salt dome has pierced some of the Catahoula Sandstone, and Aquifer $3 \mathrm{~b}$ is not present over the dome (Figure 5 and Figure 6).

\subsubsection{Vicksburg Group}

The Vicksburg Group contains Aquifer 4 and about $340 \mathrm{ft}$ of clays and soft, marly limestone. The clay and marly zone below Aquifer 4 is made up of the Redbluff Clay, Yazoo Clay, Moodys Branch Limestone, and the Cockfield Formation (Harvey and Chaffin 1963). These formations are not present over the dome (Figure 6). 


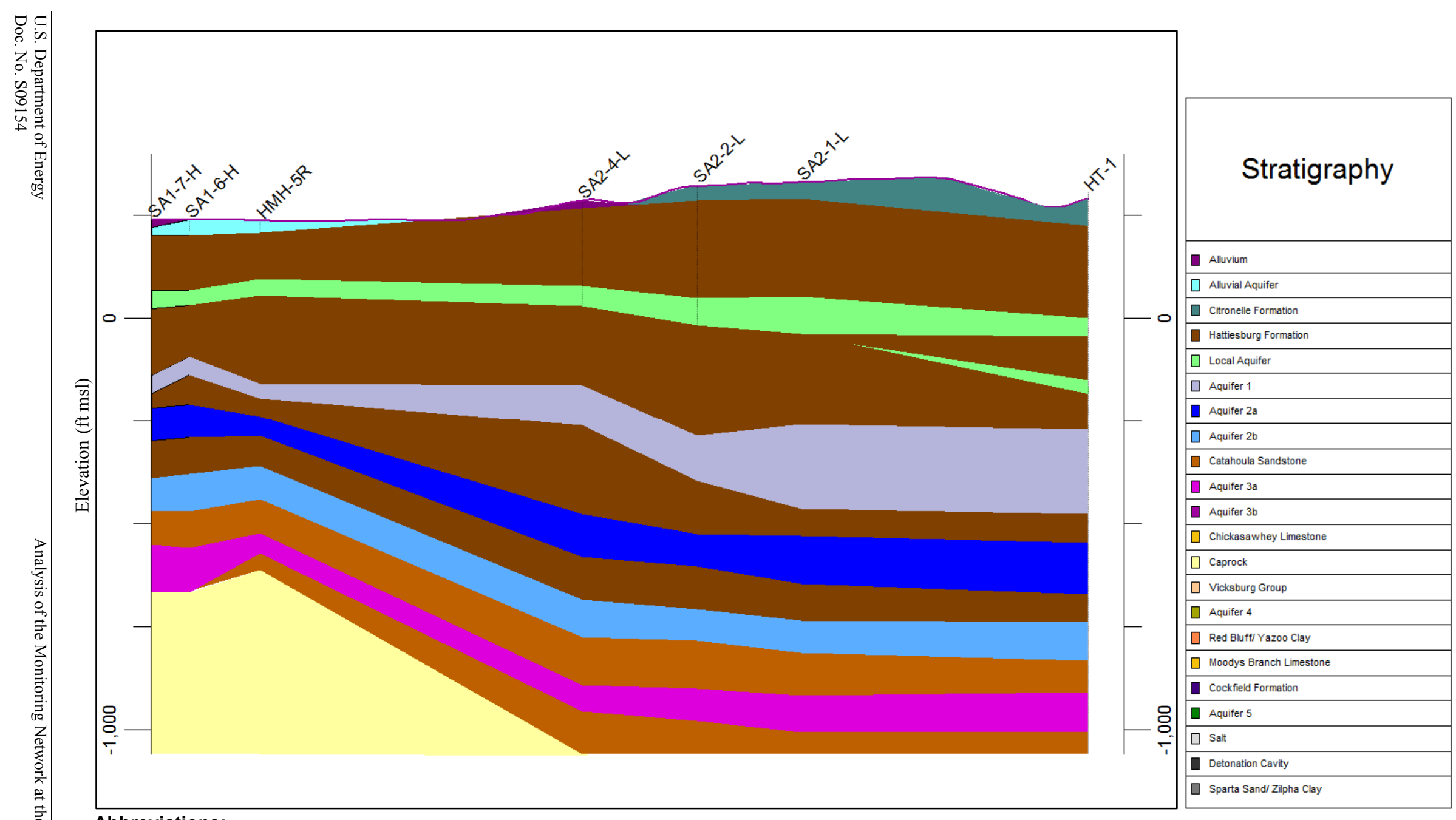

Abbreviations:

$\mathrm{msl}=$ mean sea level

Figure 4. Zoomed-In Cross Section from Well SA1-7-H to Well HT-1 


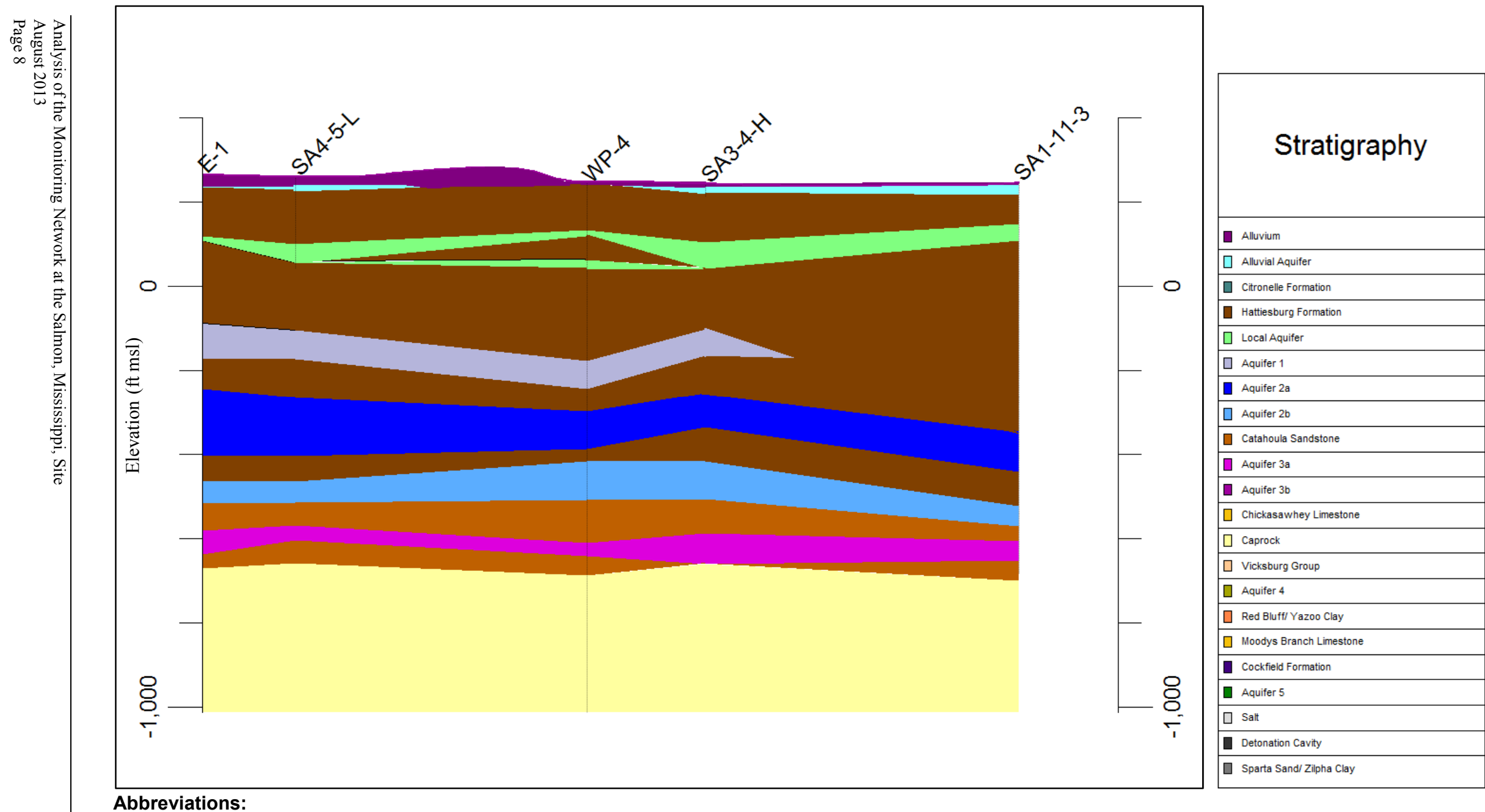

Abbreviations:

$\mathrm{msl}=$ mean sea level

Figure 5. Zoomed-In Cross Section from Well E-1 to Well SA1-11-3 


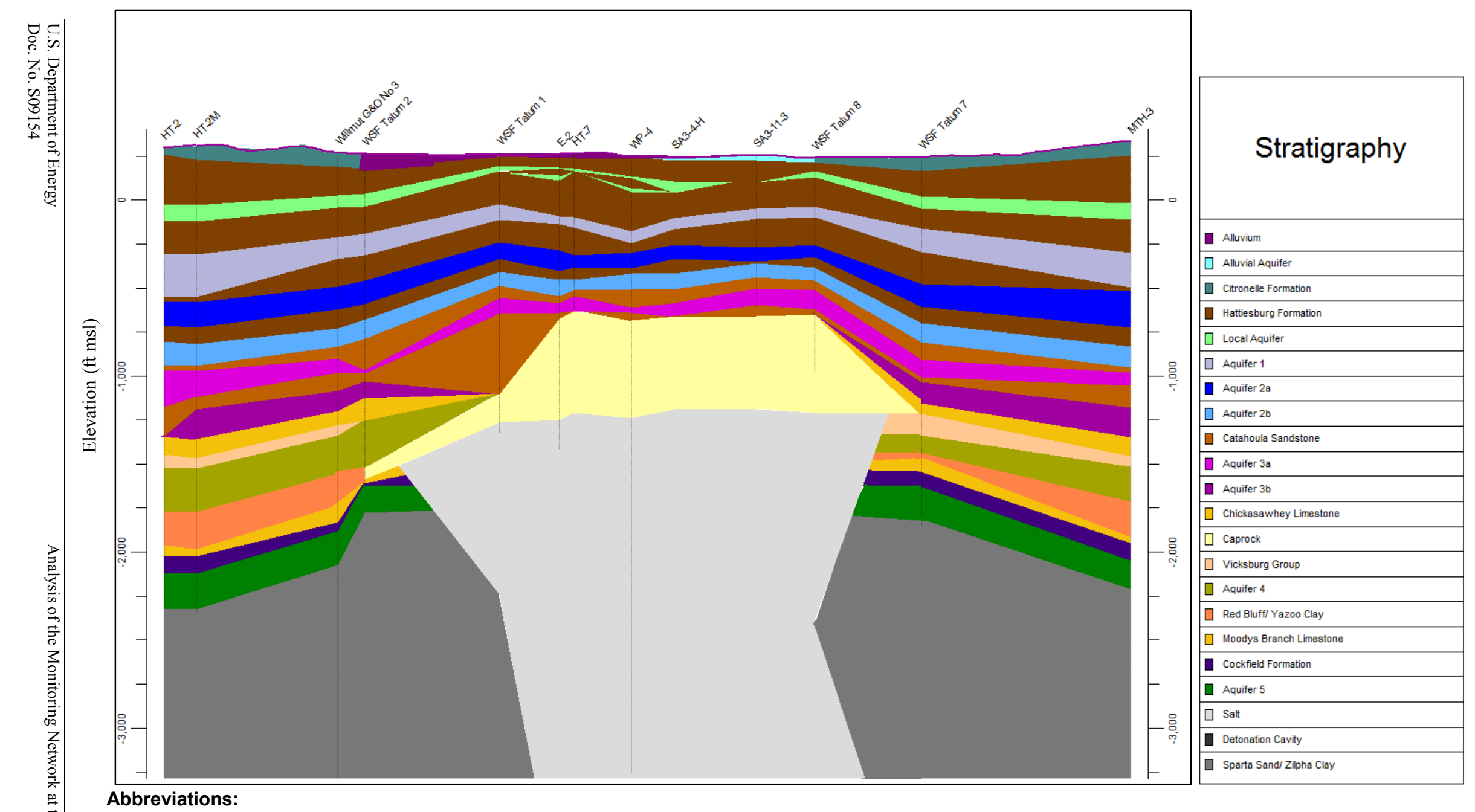

Figure 6. Cross Section from Well HT-2 to Well MTH-3 


\subsubsection{Cook Mountain Limestone}

The Cook Mountain Limestone, or Aquifer 5, is composed primarily of fine- to coarse-grained marly limestone interbedded with calcareous glauconitic clay and shale. This limestone is underlain by the Sparta Sand and Zilpha Clay (undifferentiated) and overlain by the Cockfield Formation. The Cook Mountain Limestone has been pierced by the salt dome and therefore does not overlie the dome (Figure 6).

\subsection{Hydrology}

Aquifers containing freshwater extend from near the surface to about 1,400 $\mathrm{ft}$ below sea level in the Tatum Dome area; however, the salt dome has locally modified the water quality so that freshwater over the dome extends only to about $700 \mathrm{ft}$ below sea level. Thus, some aquifers that contain saline water on the dome contain freshwater away from the influence of the dome. There are multiple freshwater aquifers: two surficial aquifers (Alluvial and Citronelle), six deeper aquifers (Local, 1, 2a, 2b, 3a, and 3b), one brackish aquifer (4), and at least one underlying saline aquifer (5) in the strata surrounding the Tatum Salt Dome. Fresh, brackish, and saline waters are defined as waters containing total dissolved solids concentrations of less than 1,000 milligrams per liter $(\mathrm{mg} / \mathrm{L}), 1,000$ to $5,000 \mathrm{mg} / \mathrm{L}$, and more than 5,000 mg/L, respectively. The freshwater aquifers Alluvial, Citronelle, and Local are discontinuous. The deeper freshwater aquifers (1, 2a, $2 \mathrm{~b}, 3 \mathrm{a}$, and $3 \mathrm{~b}$ ) are horizontally extensive, although they may be locally offset or interrupted by faults near the dome (USGS 1971). Many water supply wells in Lamar County use groundwater from one or more of these deeper freshwater aquifers. Water is also present in fractures in the cap rock and is referred to as the Caprock Aquifer. Wells in the current network are completed in most of the freshwater aquifers as well as Aquifer 4 and the Caprock Aquifer. There are 12 wells in the Alluvial Aquifer; seven in the Local Aquifer; one in each of Aquifers 1, 2a, and 2b; three in Aquifer 3a; two in Aquifer 4; and one in the Caprock Aquifer. No wells are completed in Aquifer 5, Aquifer 3b, or the Citronelle Aquifer.

\subsubsection{Alluvial Aquifer}

The Alluvial Aquifer is present at the site in the alluvial sand and gravel. This aquifer is mostly limited onsite to areas surrounding major watercourses, particularly Half Moon and Grantham Creeks. Because the aquifer was mostly created by the deposition of bed and suspended loads once carried by these creeks, the aquifer is largely absent from the western one-third of the site where streams are smaller. Recharge to the aquifer occurs via surface infiltration of precipitation. Groundwater in the aquifer flows from more elevated areas that receive recharge toward Half Moon and Grantham Creeks, where it discharges to surface water (DOE 1999).

\subsubsection{Citronelle Aquifer}

Historically, the Citronelle Aquifer was not considered to be an important aquifer in the site conceptual model. Discussions of this aquifer were left to the geology sections or it was not mentioned at all. The Citronelle Aquifer occurs at the contact of the Hattiesburg and Citronelle Formations. It is likely present onsite in areas above $250 \mathrm{ft}$ elevation. This aquifer may be relevant to the site model as it could have hydrologic connection to some of the surface water locations. 


\subsubsection{Local Aquifer}

The Local Aquifer is the uppermost aquifer within the Hattiesburg Formation. It consists of approximately $100 \mathrm{ft}$ of interbedded sand, silt, and silty clay. The top of this unit is approximately $150 \mathrm{ft}$ below ground surface. The Local Aquifer is discontinuous onsite. It appears that there is a thickening of the clay lenses within the Hattiesburg formation in some areas of the Local Aquifer. The area of the site where the Local Aquifer may not be present is south of SGZ toward well SA3-11-3. Recharge to this aquifer is partially derived from direct precipitation in areas where it crops out. Downward flow from the overlying Alluvial Aquifer is also a potential source of some water in the Local Aquifer at the Salmon site (DOE 1999).

\subsubsection{Aquifers 1, 2a, and 2b}

Aquifers 1, 2a, and 2b comprise individual water-bearing zones of the Hattiesburg Formation. These units are believed to be continuous across the Salmon site and are separated by discontinuous and less-permeable clay beds that serve as aquitards. Aquifer 1 is absent over the eastern edge of the salt dome around well E-4 (Figure 3).

\subsubsection{Aquifer 3}

Aquifer 3 is subdivided into Aquifers $3 a$ and $3 b$; these aquifers are within the Catahoula Sandstone and are influenced by the salt dome. Aquifer $3 \mathrm{a}$ is present above the dome and may contain saline water in areas where it is in contact with the cap rock. Aquifer $3 b$ is pierced by the dome and is only present on the flanks of the dome (Figure 6). Aquifer $3 \mathrm{~b}$ may also contain saline water where it is in contact with the dome.

\subsubsection{Aquifer 4}

Aquifer 4 is in the limestone of the Vicksburg Group. The water is brackish and is not used in or near the Salmon site area as a potential water supply. The Vicksburg probably is hydraulically connected to the calcite cap rock. Recharge for Aquifer 4 occurs where the Vicksburg crops out about 55 miles northeast of the Salmon site (USGS 1971).

\subsubsection{Aquifer 5}

Water from the Cook Mountain Limestone (Aquifer 5) is not used in the immediate area of the site. Brine has been injected into the Cook Mountain Limestone for more than 15 years in the vicinity of the Baxterville oil field, which is about 6 miles southwest of the dome. The quantity of brine injected into this aquifer has been sufficient to significantly change the natural head in the aquifer in the Salmon site area. Water in Aquifer 5 is confined by thick beds of clay above and below. Brine probably is moving upward in the locally deformed zone around the salt dome. Natural recharge takes place at the outcrop, which is about 75 miles northeast of the dome (USGS 1971). 


\subsubsection{Caprock Aquifer}

Groundwater occurs only in the calcite layer of the cap rock. The water is saline and is present in numerous fractures and solution cavities. The Caprock Aquifer is connected hydraulically with Aquifers $3 b$ and 4 on the flank of the dome and with Aquifer 3a over the dome (USGS 1971).

\subsection{Contaminant Sources and Pathways}

A variety of events at the Salmon site resulted in the generation of wastes. Following each of the subsurface explosions, reentry holes were drilled into the detonation cavity to determine the subsurface effects of the explosion. These drilling operations generated the largest single volume of residual waste materials, including radionuclide-contaminated drill cuttings and drilling fluids. Wastes other than radionuclide-contaminated materials were also generated as part of the testing operations. During the period of operations, more than 100 people worked onsite at a given time. The operation of the test site required fuel, electricity, sanitation, and waste disposal, as well as storage and use of hazardous materials on the site. The site was cleaned up as part of decommissioning in 1972; however, residual contamination remained in the subsurface and aquifers.

\subsection{Historical Source Areas (SAs)}

Based upon the nature of the sites and the types of activities conducted at the Salmon site, six source areas were defined (Figure 7). These source areas are described in the Remedial Investigation/Feasibility Study (RI/FS) Final Work Plan (DOE 1993) and the Work Plan Addendum (IT Corporation 1996). The following sections include excerpts of the descriptions in those documents as well as updated information about the areas from the 1993 cone penetrometer testing (CPT) conducted as part of the RI/FS (IT Corporation 1994b). Soil and water samples were taken in each of the source areas (Figure 7) and analyzed for a large suite of metals, VOCs, semivolatile organic compounds, pesticides, polychlorinated biphenyls, and radionuclides. The CPT results were summarized in tables in Task Summary for Cone Penetrometer Testing Sounding and Soil and Groundwater Sampling, Salmon Site, Lamar County, Mississippi (IT Corporation 1994b), which incorrectly reported some of the VOC results(chloroethene was mistakenly written as chloroethane). Tables 1 and 2 in this report show the corrections and Appendix A shows the results from the database confirming the corrections.

\subsubsection{Source Area 1: Surface Ground Zero}

The area around SGZ encompasses a number of sites where soil or groundwater contamination was known or suspected. The individual sites within this source area include the Station 1-A Shot Cavity and Mud Pit, the Beaver Pond, the Half Moon Creek Overflow Pond, the Post-Shot No. 1 Slush Pit and Mouse Hole, the former Bleed-Down Plant Area, the East Substation, the E-14 Pad and Mud Pits, the Post-Shot No. 2 Mud Pit, and the E-6 Decontamination Pad. These sites were included in a single source area because of their geographic proximity on the west side of Half Moon Creek and the nature of activities that were conducted at the sites. Four of the sites were used for the disposal of wastes. 


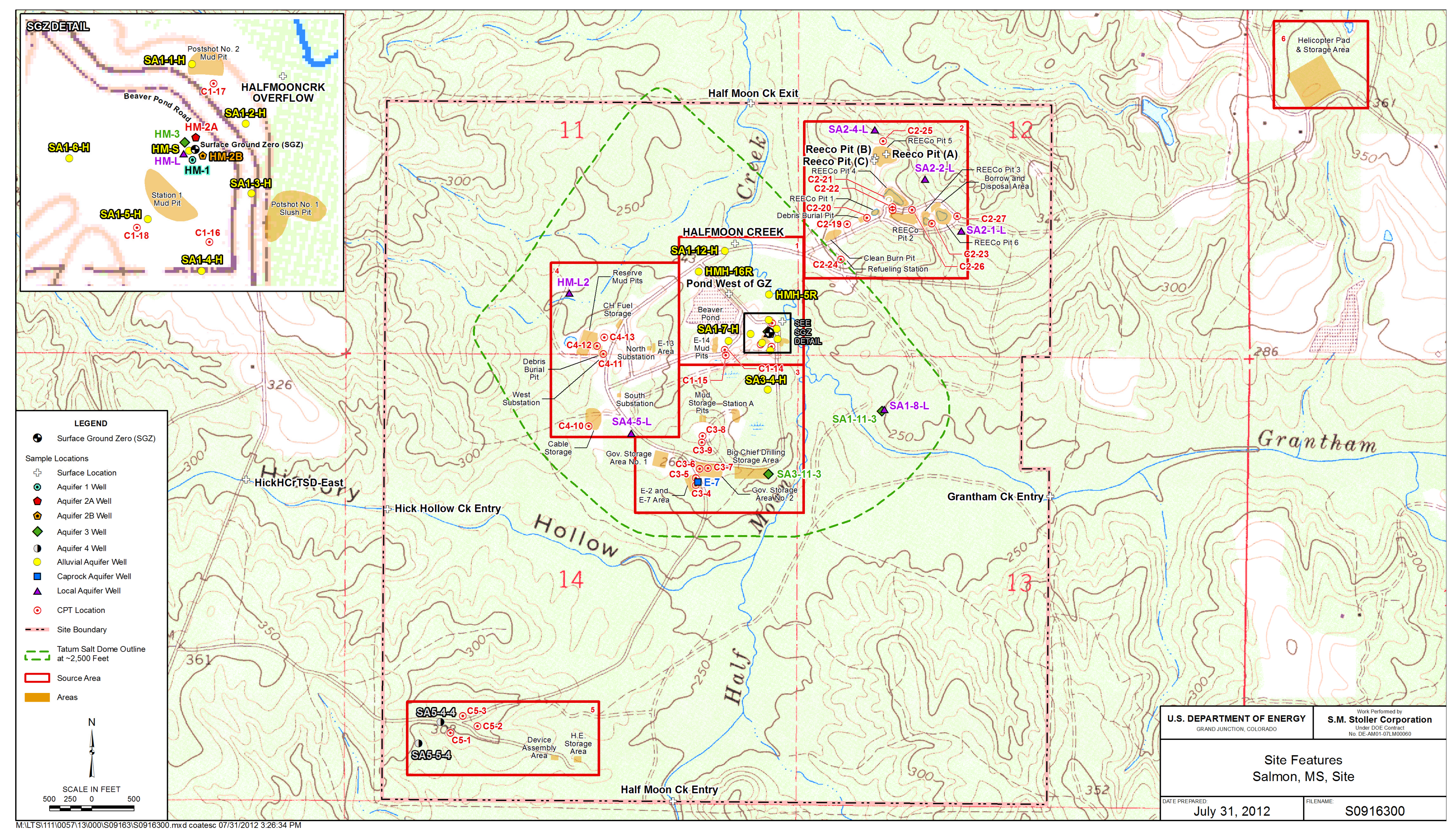

Figure 7. Monitoring Network, Historical Source Areas, and CPT Locations 
This page intentionally left blank 


\section{Station 1-A Shot Cavity}

The Station 1-A Shot Cavity is located in SGZ and includes both the cavity formed by the Salmon detonation and the Station 1-A reentry boring that was drilled into the cavity. Following the detonation, the cavity was used to dispose of soils excavated from contaminated areas. Material was transported and deposited onto a holding pad adjacent to the reentry boring. The soil was then placed in a hopper at the borehole collar via a conveyor belt. Contaminated water from various onsite tanks and clean water from Half Moon Creek were mixed with the contaminated soils to produce a slurry, which was injected into the shot cavity.

\section{Beaver Pond}

The Beaver Pond was excavated during site decommissioning. Beavers subsequently dammed the drain culverts, and the pond formed to the west of SGZ. Monitoring well HMH-16, installed near the Beaver Pond and sampled in 1990, contained tritiated water. Well HMH-16 was replaced with HMH-16R in March 2002. Enriched tritium analysis was conducted in well HMH-16R in 2010; analysis indicated the presence of tritium at or near background levels.

\section{Half Moon Creek Overflow Pond}

Although not intended as a waste facility, the Half Moon Creek Overflow Pond received purge water generated as part of the monitoring program that has been ongoing since 1970. Tritiated groundwater generated during purging and sampling of monitoring wells HM-S and HM-L was discharged to the ground surface. This water drained to the Half Moon Creek Overflow Pond via natural drainages.

\section{Post-Shot No. 1 Slush Pit}

The Post-Shot No. 1 Slush Pit was located at the extreme southern portion of the Station 1-A area and was excavated for use as a liquid waste storage pit during the Salmon event post-shot drilling operations. The pit was filled with drilling sludge and covered with clean soil. Subsequent erosion and flooding resulted in contamination of the South Road area and the adjacent swamp. During site decommissioning, the excavation of the slush pit and adjacent contaminated areas was hampered by the presence of shallow groundwater. As a consequence, the cleanup and decommissioning was completed by backfilling the excavation with clean fill.

\section{Post-Shot No. 2 Mud Pit}

The Post-Shot No.2 Mud Pit was a 15 meter $(\mathrm{m})$ x $15 \mathrm{~m}(50 \mathrm{ft} \times 50 \mathrm{ft})$ drilling mud pit located about $45 \mathrm{~m}$ (148 ft) north of SGZ. A site inspection conducted during August 1990 found no indication of the pit remaining; however, geophysical investigations conducted in 1993 were able to accurately define the pit location (IT Corporation 1994a). The pit was used after testing activities for the storage of drilling fluids. Possible contaminants include volatile organics, metals, and fuels associated with drilling operations. 


\section{SA1 1993 RI/FS Constituents}

Soil and water samples were taken from the five CPT locations in SA1 (Figure 7). Table 1 summarizes the constituents that were detected and whether they exceeded an established maximum contaminant level (MCL).

Table 1. SA1 CPT Sampling Results

\begin{tabular}{|c|c|c|c|c|}
\hline $\begin{array}{c}\text { CPT } \\
\text { Location }\end{array}$ & $\begin{array}{c}\text { Sample } \\
\text { Matrix }\end{array}$ & Organics & Metals & Radionuclides \\
\hline \multirow[b]{2}{*}{ C1-14 } & Soil & ND & $\mathrm{Cr}$ and $\mathrm{Pb}$ detected. & ND \\
\hline & Water & ND & $\begin{array}{l}\mathrm{Hg} \text { and } \mathrm{Ni} \text { detected. } \\
\mathrm{Ba}, \mathrm{Cd}, \mathrm{Cr} \text {, and } \mathrm{Pb} \text { exceeded MCLs. }\end{array}$ & $\begin{array}{l}\text { TI-208, Pb-212, Bi-214, } \\
\text { Ra-226, Ra-228, and gross } \\
\text { alpha/beta detected. }\end{array}$ \\
\hline \multirow[b]{2}{*}{ C1-15 } & Soil & $\begin{array}{l}\text { Carbon disulfide } \\
\text { detected. } \\
\end{array}$ & $\mathrm{Cr}$ and $\mathrm{Pb}$ detected. & ND \\
\hline & Water & ND & $\begin{array}{l}\mathrm{As}, \mathrm{Hg}, \text { and } \mathrm{Ni} \text { detected. } \\
\mathrm{Ba}, \mathrm{Cd}, \mathrm{Cr} \text {, and } \mathrm{Pb} \text { exceeded MCLs. }\end{array}$ & $\begin{array}{l}\mathrm{K}-40, \mathrm{~Pb}-212, \mathrm{Ra}-226, \text { and } \\
\mathrm{Ra}-228 \text { detected. } \\
\text { Gross alpha/beta } \\
\text { exceeded MCLs. }\end{array}$ \\
\hline \multirow[b]{2}{*}{ C1-16 } & Soil & ND & $\mathrm{Cr}$ and $\mathrm{Pb}$ detected. & $\mathrm{K}-40$ detected. \\
\hline & Water & ND & $\begin{array}{l}\text { As, } \mathrm{Ba}, \mathrm{Hg} \text {, and } \mathrm{Ni} \text { detected. } \\
\mathrm{Cr} \text { and } \mathrm{Pb} \text { exceeded MCLs. }\end{array}$ & $\begin{array}{l}\text { Gross alpha/beta } \\
\text { exceeded MCLs. }\end{array}$ \\
\hline \multirow[b]{2}{*}{ C1-17 } & Soil & TCE* detected. & $\mathrm{Cr}$ and $\mathrm{Pb}$ detected. & Bi-214 and Ra-226 detected. \\
\hline & Water & $\begin{array}{l}\text { 1,2-DCE** and TCE* } \\
\text { detected. }\end{array}$ & $\begin{array}{l}\text { As, } \mathrm{Ba}, \mathrm{Hg} \text {, and } \mathrm{Ni} \text { detected. } \\
\mathrm{Cr} \text { and } \mathrm{Pb} \text { exceeded MCLs. }\end{array}$ & $\begin{array}{l}\mathrm{Pb}-212 \text { and tritium detected. } \\
\text { Gross alpha/beta } \\
\text { exceeded MCLs. }\end{array}$ \\
\hline \multirow[b]{2}{*}{ C1-18 } & Soil & ND & $\mathrm{Cr}$ and $\mathrm{Pb}$ detected. & ND \\
\hline & Water & $\begin{array}{l}\text { Carbon disulfide } \\
\text { detected. } \\
\text { 1,2-DCE }{ }^{* *} \text { exceeded } \\
\text { MCL. }\end{array}$ & $\begin{array}{l}\text { As, } \mathrm{Pb}, \mathrm{Hg} \text {, and } \mathrm{Ni} \text { detected. } \\
\text { Cr exceeded the MCLs. }\end{array}$ & $\begin{array}{l}\text { Gross alpha/beta detected. } \\
\text { Gross beta exceeded MCL. }\end{array}$ \\
\hline
\end{tabular}

Notes:

* Listed incorrectly as Trichloroethane in a 1994 publication (IT Corporation 1994b)

** Listed incorrectly as 1, 2-dichloroethane in a 1994 publication (IT Corporation 1994b)

Abbreviations:

$\mathrm{Bi}=$ bismuth

$\mathrm{Hg}=$ mercury

$\mathrm{K}=$ potassium

$\mathrm{ND}=$ not detected

$\mathrm{Ra}=$ radium

$\mathrm{TI}=$ thallium

\section{Current SA1 Sampling Locations}

SA1 currently contains 18 wells and 3 surface sampling locations (Figure 7). Eleven of the wells monitor the Alluvial Aquifer, two are in the Local Aquifer, two are in Aquifer 3a, and one each is in Aquifers 1, 2a, and 2b. The surface locations are the Beaver Pond, Half Moon Creek, and Half Moon Creek Overflow. 


\subsubsection{Source Area 2: Northern Disposal Area}

The Northern Disposal Area encompasses all former waste disposal sites on the east side of Half Moon Creek, including the Reynolds Electrical and Engineering Company Inc. (REECo) Disposal Pits (noncombustible material disposal areas and the borrow and disposal area), the Debris Burial Pit, the Clean Burn Pit, and the former gas pump location (Figure 7). These sites were included in a single source area because of the similar types of historical waste disposal and their geographical proximity; also, their location on the east side of Half Moon Creek places them in a somewhat different hydrogeologic setting than other source areas. The groundwater flow in the surficial aquifer underlying this source area is believed to be primarily to the west, following site topography, unlike at other source areas where flow through the surficial aquifer is primarily to the east. Source Area 2 includes sites that were used for the disposal of wastes. The historical waste disposal activities are summarized below.

\section{REECo Disposal Pits}

Six disposal pits and a borrow pit were located to the northeast of SGZ within the Northern Disposal Area (Figure 7). This area is also referred to as the REECo Disposal Pits. The borrow pit was originally used to contain drilling mud. During site decommissioning, the pit was used for the disposal of noncombustible materials and uncontaminated tools and equipment. In 1988 a headcut gully was observed that was approximately $15 \mathrm{ft}$ deep and 20 to $25 \mathrm{ft}$ wide. Wastes that were observed in the bottom of this gully included wire, steel, bricks, concrete slabs, and badly corroded drums. These drums, based upon information provided to DOE by a former site guard, contained personal protective equipment, such as gloves and coveralls, which were placed in plastic bags, containerized in 25- or 30-gallon drums, and then disposed of in the borrow pit. However, the material observed in the gully might be only riprap dumped to control headcutting. Additional inspections of the area during 1993 did not identify any drums or personal protective equipment. A geophysical survey was conducted over the entire REECo Disposal Pits area during 1993 (IT Corporation 1994a). The results of that study identified numerous magnetic anomalies across the site. The anomalies were attributed to the metallic surface debris such as fencing, fence posts, and concrete reinforcing wire. Subsequent trenching activities in other areas of the pits located small quantities of metal debris related to site operations and large quantities of drilling mud disposed of in earthen pits and covered with clean fill. No buried drums were located, although steel debris and electrical cables were found, indicating that the information about the drums from 1988 may have been wrong or possibly that the drums were removed when discovered in 1988.

\section{Debris Disposal Pits}

A debris disposal pit was located about $50 \mathrm{ft}$ west of the REECo Disposal Pits. The types of materials disposed at this site are unknown. The geophysical investigation of this site indicated several large magnetic anomalies. Subsequent trenching of the area uncovered buried steel, electrical cables, and assorted scrap metal. A portion of this site was also found to have been used for burning. 


\section{Clean Burn Pit}

A burn pit was located about $500 \mathrm{ft}$ west of the REECo Disposal Pits. Because this pit was used for the incineration of nonradioactive materials, it was referred to as the Clean Burn Pit. No information concerning the operation of this pit is available; however, such pits are commonly used for the incineration of combustible debris and spent oils and solvents.

\section{Refueling Station}

During site operations, a refueling station was located adjacent to the main road at the junction of the Sandpit Road. The station was most likely used to dispense gasoline and diesel fuel and had an underground storage tank and possibly an adjacent aboveground storage tank. Possible contaminants at this site are petroleum hydrocarbons and lead (from leaded gasoline).

\section{Seeps in the REECo Disposal Pits Area}

The RI/FS final work plan discusses a seep discovered in the borrow pit area in 1990 with above-background tritium concentrations. However, the reference given places the seep near well HT-2, which is in SA5 in the southwest corner of the site. Therefore, it is not clear whether there was a seep in the borrow pit area.

In 1983 a seep in the area of REECo Pit 5 was sampled and tritium was detected at a concentration of 12,000 picocuries per liter (pCi/L) (IT Corporation 1996). This result was more than six times the historical values, and subsequent sampling has not resulted in a spike this high.

\section{SA2 1993 RI/FS Constituents}

Soil and water samples were taken from the nine CPT locations in SA2. Table 2 summarizes the constituents that were detected and whether they exceeded an MCL.

Table 2. SA2 CPT Sampling Results

\begin{tabular}{|c|c|c|c|c|}
\hline $\begin{array}{c}\text { CPT } \\
\text { Location }\end{array}$ & \begin{tabular}{|c|} 
Sample \\
Matrix
\end{tabular} & Organics & Metals & Radionuclides \\
\hline \multirow[b]{2}{*}{ C2-19 } & Soil & Toluene detected. & Cr and $\mathrm{Pb}$ detected. & $\begin{array}{l}\mathrm{K}-40, \mathrm{~Pb}-210, \mathrm{~Pb}-212, \mathrm{Ra}-226 \\
\text { Th-234, and gross alpha/beta } \\
\text { detected. }\end{array}$ \\
\hline & Water & $\begin{array}{l}\text { Diethyl phthalate, } \\
\text { beta-BHC, aldrin, and } \\
\text { heptachlor epoxide } \\
\text { detected. }\end{array}$ & $\begin{array}{l}\text { As and } \mathrm{Ni} \text { detected. } \\
\mathrm{Cr} \text { and } \mathrm{Pb} \text { exceeded MCLs. }\end{array}$ & $\begin{array}{l}\text { Ra-226, Th-234, gross } \\
\text { alpha/beta detected. } \\
\text { Gross beta exceeded MCL. }\end{array}$ \\
\hline \multirow[t]{2}{*}{$C 2-20$} & Soil & ND & Cr detected. & $\begin{array}{l}\mathrm{K}-40, \mathrm{TI}-208, \mathrm{~Pb}-210, \mathrm{~Pb}-212, \\
\mathrm{Ra}-226, \mathrm{Ra}-228, \mathrm{Th}-234, \text { and } \\
\text { gross alpha/beta detected. }\end{array}$ \\
\hline & Water & Not sampled. & Not sampled. & Not sampled. \\
\hline \multirow{2}{*}{$C 2-21$} & Soil & ND & $\mathrm{Pb}$ detected. & ND \\
\hline & Water & Not sampled. & Not sampled. & Not sampled. \\
\hline \multirow{2}{*}{$\mathrm{C} 2-22$} & Soil & ND & $\mathrm{Cr}$ and $\mathrm{Pb}$ detected. & Bi-214 detected. \\
\hline & Water & Not sampled. & Not sampled. & Not sampled. \\
\hline \multirow[t]{2}{*}{$\mathrm{C} 2-23$} & Soil & ND & $\mathrm{Cr}$ and $\mathrm{Pb}$ detected. & $\begin{array}{l}\text { TI-208, Pb-212, and Ra-226 } \\
\text { detected. }\end{array}$ \\
\hline & Water & Not sampled. & Not sampled. & Not sampled. \\
\hline
\end{tabular}


Table 2 (continued). SA2 CPT Sampling Results

\begin{tabular}{|c|c|c|c|c|}
\hline $\begin{array}{c}\text { CPT } \\
\text { Location }\end{array}$ & $\begin{array}{c}\text { Sample } \\
\text { Matrix }\end{array}$ & Organics & Metals & Radionuclides \\
\hline \multirow[t]{2}{*}{$\mathrm{C} 2-24$} & Soil & ND & $\mathrm{Ba}$ and $\mathrm{Pb}$ detected. & $\begin{array}{l}\text { Pb-212 and Ra-226 gross beta } \\
\text { detected. }\end{array}$ \\
\hline & Water & ND & Not sampled. & ND \\
\hline \multirow[t]{2}{*}{ C2-25 } & Soil & ND & $\mathrm{Cr}$ and $\mathrm{Pb}$ detected. & $\begin{array}{l}\text { TI-208, Pb-212, Ra-224, and } \\
\text { Ra-226 detected. }\end{array}$ \\
\hline & Water & Not sampled. & Not sampled. & Not sampled. \\
\hline \multirow{2}{*}{$\mathrm{C} 2-26$} & Soil & ND & $\mathrm{Cr}$ and $\mathrm{Pb}$ detected. & Pb-212 detected. \\
\hline & Water & Not sampled. & Not sampled. & Not sampled. \\
\hline \multirow[b]{2}{*}{$\mathrm{C} 2-27$} & Soil & ND & $\mathrm{Pb}$ detected. & $\begin{array}{l}\mathrm{K}-40, \mathrm{TI}-208, \mathrm{~Pb}-210, \mathrm{~Pb}-212, \\
\mathrm{Ra}-226, \mathrm{Ra}-228, \mathrm{Th}-234, \text { and } \\
\text { gross alpha/beta detected. }\end{array}$ \\
\hline & Water & $\begin{array}{l}\text { Perchloroethene } \\
(\mathrm{PCE})^{*} \text { detected at } \\
\text { the detection limit. }\end{array}$ & $\begin{array}{l}\mathrm{Ni} \text { detected. } \\
\mathrm{Ba}, \mathrm{Cr}, \mathrm{Hg} \text {, and } \mathrm{Pb} \text { exceeded MCLs. }\end{array}$ & $\begin{array}{l}\mathrm{K}-40, \mathrm{TI}-208, \mathrm{~Pb}-210, \mathrm{~Pb}-212, \\
\text { and } \mathrm{Ra}-226 \text { detected. } \\
\text { Gross alpha/beta } \\
\text { exceeded MCLs. }\end{array}$ \\
\hline
\end{tabular}

Notes

* Listed incorrectly as tetrachloroethane in a 1994 publication (IT Corporation 1994b)

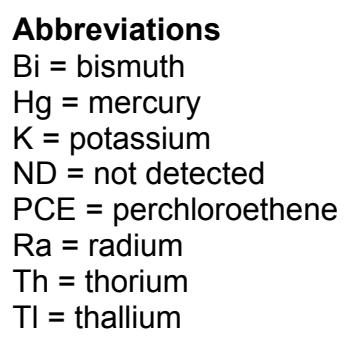

\section{Current SA2 Sampling Locations}

Three surface water sampling locations are currently located in the area of the REECo Disposal Pits and are referred to as REECo Pit (A), REECo Pit (B), and REECo Pit (C). These surface water locations are all from seeps in the REECo Pit 5 area (Figure 7). Three monitoring wells (SA2-1-L, SA2-2-L, and SA2-4-L) are also located in SA2; all are completed in the Local Aquifer.

\subsubsection{Source Area 3: Southern Storage Area}

Originally, only storage sites were thought to be included in Source Area 3 because no waste disposal sites are known to have been operated within this source area. The Mud Storage Area may have residual drilling mud in pits and is a potential source of contamination with metals and trace levels of radionuclides. Several exploratory holes were drilled in the area during site operations and drilling mud pits associated with these operations may be a potential source of contamination from metals, and petroleum hydrocarbons.

\section{Mud Storage Area}

This site appears to have been graded during site construction. Drilling fluids were apparently stored in earthen pits at this site and it is also possible that this was the site of the drilling fluids mixing plant. 


\section{Big Chief Drilling Storage Area}

This site was used to store drilling equipment. Potential contaminants are fuel, lubricants, and solvents used in the maintenance of equipment.

\section{E-2 and E-7 Drilling Locations}

This site is located along the road to the west gate of the site. Two exploratory wells were drilled at this location. Potential contaminants are petroleum hydrocarbons and heavy metals associated with drilling operations.

\section{Government Storage Area 1}

This site was used to store drilling equipment. Potential contaminants are fuel, lubricants, and solvents used in the maintenance of equipment.

\section{SA3 1993 RI/FS Constituents}

Soil and water samples were taken from the six CPT locations in SA3. Table 3 summarizes the constituents that were detected and whether they exceeded an MCL.

\section{Current SA3 Sampling Locations}

Three monitoring wells are currently located in SA3: SA3-4-H, screened in the Alluvial Aquifer; SA3-11-3, screened in Aquifer 3; and E7, screened in the Caprock Aquifer (Figure 7). 
Table 3. SA3 CPT Sampling Results

\begin{tabular}{|c|c|c|c|c|}
\hline $\begin{array}{c}\text { CPT } \\
\text { Location }\end{array}$ & $\begin{array}{c}\text { Sample } \\
\text { Matrix }\end{array}$ & Organics & Metals & Radionuclides \\
\hline \multirow[t]{2}{*}{ C3-4 } & Soil & ND & As, $\mathrm{Cr}$, and $\mathrm{Pb}$ detected. & $\begin{array}{l}\mathrm{K}-40, \mathrm{TI}-208, \mathrm{~Pb}-210, \mathrm{~Pb}-212, \\
\mathrm{Ra}-226, \text { and } \mathrm{Ra}-228 \text { detected. }\end{array}$ \\
\hline & Water & Not sampled. & Not sampled. & Not sampled. \\
\hline \multirow[t]{2}{*}{ C3-5 } & Soil & ND & As and $\mathrm{Pb}$ detected. & $\begin{array}{l}\text { TI-208, Pb-212, Ra-226, and } \\
\text { gross alpha/beta detected. }\end{array}$ \\
\hline & Water & Not sampled. & Not sampled. & Not sampled. \\
\hline \multirow[t]{2}{*}{ C3-6 } & Soil & ND & As, $\mathrm{Ba}$, and $\mathrm{Pb}$ detected. & $\begin{array}{l}\text { TI-208, Pb-212, Ra-228, and } \\
\text { gross alpha/beta detected. }\end{array}$ \\
\hline & Water & Not sampled. & Not sampled. & Not sampled. \\
\hline \multirow[t]{2}{*}{ C3-7 } & Soil & ND & As, $\mathrm{Cr}$, and $\mathrm{Pb}$ detected. & $\begin{array}{l}\mathrm{K}-40, \mathrm{Tl}-208, \mathrm{~Pb}-212, \mathrm{Ra}-226, \\
\text { and gross alpha/beta detected. }\end{array}$ \\
\hline & Water & Not sampled. & Not sampled. & Not sampled. \\
\hline \multirow{2}{*}{ C3-8 } & Soil & ND & $\mathrm{Ba}$ and $\mathrm{Pb}$ detected. & $\begin{array}{l}\mathrm{K}-40, \mathrm{Tl}-208, \mathrm{~Pb}-212, \mathrm{Ra}-226, \\
\text { and gross alpha/beta detected. }\end{array}$ \\
\hline & Water & ND & $\begin{array}{l}\text { As and } \mathrm{Ni} \text { detected. } \\
\mathrm{Ba}, \mathrm{Cr} \text {, and } \mathrm{Pb} \text { exceeded MCLs. }\end{array}$ & $\begin{array}{l}\mathrm{K}-40, \mathrm{~Pb}-212 \text {, gross alpha/beta, } \\
\text { and tritium detected. }\end{array}$ \\
\hline \multirow{2}{*}{ C3-9 } & Soil & ND & As and $\mathrm{Pb}$ detected. & $\begin{array}{l}\mathrm{Pb}-212 \text { and gross alpha/beta } \\
\text { detected. }\end{array}$ \\
\hline & Water & $\begin{array}{l}\text { Toluene and endosulfan } \\
\text { sulfate detected. }\end{array}$ & $\begin{array}{l}\text { As and } \mathrm{Ni} \text { detected. } \\
\mathrm{Ba}, \mathrm{Cr} \text {, and } \mathrm{Pb} \text { exceeded MCLs. }\end{array}$ & $\begin{array}{l}\mathrm{K}-40, \mathrm{~Pb}-212, \mathrm{Ra}-226, \text { and } \\
\text { gross alpha/beta detected. }\end{array}$ \\
\hline
\end{tabular}

\section{Abbreviations}

$\mathrm{K}=$ potassium

$\mathrm{ND}=$ not detected

$\mathrm{Ra}=$ radium

$\mathrm{TI}=$ thallium

\subsubsection{Source Area 4: Western Disposal Area}

The Western Disposal Area encompasses the Reserve Mud Pits; the Debris Burial Pit; the North, West, and South Substations; the CH Fuel Storage Area; and the Cable Storage Area. These sites were included in a single source area because of their geographic proximity and because the nature of the sites indicates that the radionuclide contaminants that are the primary concern at Source Area 1 (SGZ) are probably not present at these sites. Source Area 4 includes two sitesthe Reserve Mud Pits and the Debris Burial Pit — that may have been used for the disposal of wastes.

\section{Reserve Mud Pits}

The Reserve Mud Pits were located about 2,000 ft west of SGZ. These pits were used for mixing drilling fluids for the emplacement and reentry borings. Although there are no data indicating that the pits were used for waste disposal, residual drilling mud may be present. The primary potential contaminants are related to the drilling fluids used in the construction of the shafts and fuels and lubricating oils used for the drilling equipment. 


\section{Debris Burial Pit}

The Debris Burial Pit is located about 2,000 ft west of SGZ. No information is available on this area. The area was presumed to be used for the disposal of construction debris and rubbish, and it is unknown whether it was used for disposal of hazardous nonradioactive substances.

\section{SA4 1993 RI/FS Constituents}

Soil and water samples were taken from the four CPT locations in SA4. Table 4 summarizes the constituents that were detected and whether they exceeded an MCL.

Table 4. SA4 CPT Sampling Results

\begin{tabular}{|c|c|c|c|c|}
\hline $\begin{array}{c}\text { CPT } \\
\text { Location }\end{array}$ & $\begin{array}{c}\text { Sample } \\
\text { Matrix }\end{array}$ & Organics & Metals & Radiological \\
\hline \multirow[t]{2}{*}{ C4-10 } & Soil & ND & $\mathrm{Pb}$ detected. & $\begin{array}{l}\mathrm{K}-40, \mathrm{TI}-208, \mathrm{~Pb}-212, \mathrm{Ra}-226, \\
\text { Ra-228 and gross alpha/beta } \\
\text { detected. }\end{array}$ \\
\hline & Water & Not sampled. & Not sampled. & Not sampled. \\
\hline \multirow[t]{2}{*}{ C4-11 } & Soil & ND & As and $\mathrm{Pb}$ detected. & $\begin{array}{l}\mathrm{K}-40, \mathrm{TI}-208, \mathrm{~Pb}-210, \mathrm{~Pb}-212 \text {, } \\
\text { Ra-226, and gross alpha/beta } \\
\text { detected. }\end{array}$ \\
\hline & Water & ND & $\begin{array}{l}\mathrm{Hg} \text { and } \mathrm{Ni} \text { detected. } \\
\mathrm{Ba}, \mathrm{Cr} \text {, and } \mathrm{Pb} \text { exceeded MCLs. }\end{array}$ & $\begin{array}{l}\mathrm{Pb}-212, \mathrm{Ra}-226, \text { and gross } \\
\text { alpha/beta detected. }\end{array}$ \\
\hline \multirow{2}{*}{ C4-12 } & Soil & ND & $\mathrm{Cr}$ and $\mathrm{Pb}$ detected. & ND \\
\hline & Water & Not sampled. & Not sampled. & Not sampled. \\
\hline \multirow{2}{*}{ C4-13 } & Soil & ND & $\mathrm{Pb}$ detected. & $\begin{array}{l}\mathrm{K}-40, \mathrm{TI}-208, \mathrm{~Pb}-212, \mathrm{Ra}-226, \\
\text { and gross alpha/beta detected. }\end{array}$ \\
\hline & Water & ND & $\begin{array}{l}\text { Ba detected. } \\
\mathrm{Cr} \text { and } \mathrm{Pb} \text { exceeded MCLs. }\end{array}$ & $\begin{array}{l}\text { K- } 40, \text { gross alpha/beta, and } \\
\text { tritium detected. }\end{array}$ \\
\hline
\end{tabular}

\footnotetext{
Abbreviations

$\mathrm{Hg}=$ mercury

$\mathrm{K}=$ potassium

$\mathrm{ND}=$ not detected

$\mathrm{Ra}=$ radium

$\mathrm{TI}=$ thallium
}

\section{Current SA4 Sampling Locations}

SA4 currently has two monitoring wells, HM-L2 and SA4-5-L, both completed in the Local Aquifer (Figure 7).

\subsubsection{Source Area 5: Injection Well Area}

The Injection Well Area is of limited extent, encompassing the former injection well HT-2, the former monitoring well HT-2M, and the area around these wells where surficial contamination may have resulted during site operations and decommissioning. The area surrounding the injection well is considered as a single source area because of the nature of waste disposal (deep well disposal) and geographic separation from the other source areas. Well HT-2 was used for the injection of radioactively contaminated water into Aquifer 5. Prior to injection of the waste, 2,000 gallons of 15 percent hydrochloric acid was injected to increase the effective porosity and holding capacity of the Cook Mountain Limestone. Following the acid treatment, 
337,900 gallons of radioactively contaminated water was injected into Aquifer 5 via the well. The waste had a total activity of 38 curies of beta-gamma emitters and 3,253 curies of tritium. Following injection of the waste, an additional 90,000 gallons of freshwater was injected.

Well HT-2 was plugged and abandoned as part of site decommissioning. Well HT-2M was drilled as a monitoring well, which was subsequently plugged and abandoned when the well

became artesian.

\section{SA5 1993 RI/FS Constituents}

Soil and water samples were taken from the three CPT locations in SA5. Table 5 summarizes the constituents that were detected. No detections exceeded an MCL.

Table 5. SA5 CPT Sampling Results

\begin{tabular}{||c|c|l|l|l||}
\hline $\begin{array}{c}\text { CPT } \\
\text { Location }\end{array}$ & $\begin{array}{c}\text { Sample } \\
\text { Matrix }\end{array}$ & \multicolumn{1}{|c|}{ Organics } & \multicolumn{1}{|c||}{ Metals } & \multicolumn{1}{|c||}{ Radiological } \\
\hline \multirow{3}{*}{ C5-1 } & Soil & ND & Cr and Pb detected. & $\begin{array}{l}\text { K-40, Pb-210, Pb-212, Ra-226, and } \\
\text { gross alpha/beta detected. }\end{array}$ \\
\cline { 2 - 5 } & Water & ND & Cr and Pb detected. & K-40 and gross alpha/beta detected. \\
\hline \multirow{2}{*}{ C5-2 } & Soil & ND & Cr and Pb detected. & Pb-212 detected. \\
\cline { 2 - 5 } & Water & Not sampled. & Not sampled. & Not sampled. \\
\hline \multirow{2}{*}{ C5-3 } & Soil & ND & Ba, Cr, and Pb detected. & Pb-212 and Ra-226 detected. \\
\cline { 2 - 5 } & Water & Not sampled. & Not sampled. & Not sampled. \\
\hline
\end{tabular}

Abbreviations

$\mathrm{K}=$ potassium

$\mathrm{ND}=$ not detected

$\mathrm{Ra}=$ radium

\section{Current SA5 Sampling Locations}

SA5 has two wells, SA5-4-4 and SA5-5-4, that are completed in Aquifer 4 to monitor for the potential upward migration of contamination from Aquifer 5.

\subsubsection{Source Area 6: Helicopter Pad and Storage Area}

The Helicopter Pad and Storage Area is of limited extent and encompasses only the former landing site northeast of the Salmon site. This site was included as a source area because of its remoteness from other source areas and the unique activities that were conducted at the site. Source Area 6 does not include any sites that were known to be used for the disposal of wastes and is not monitored as part of the well network.

\subsection{Contaminant Pathways}

The Salmon site has two main categories of contamination: the residual surface contamination left from site activities in each of the source areas and the potential for future contamination from the shot cavity and Aquifer 5. The most likely pathway for contaminants released at the surface in the Half Moon Creek floodplain (alluvium) is laterally toward the creek. Because of the observed downward gradient at the site, the potential also exists for downward migration to underlying aquifers. The primary migration pathway for contaminants in the test cavity would be through the emplacement and reentry wellbores; the thickness and near-impermeability of the salt that separates the detonation cavity from water-bearing zones adjacent to the dome would effectively inhibit lateral migration of contaminants. 


\subsubsection{Current Contaminants}

The historical descriptions of the waste disposal activities, combined with the CPT results from 1993 and the current sampling results, allow a reasonably complete interpretation of contaminants currently onsite.

\section{Metals}

The current metal constituents onsite are arsenic, barium, chromium, lead, and zinc. Though samples are analyzed for a larger suite of metals, these five are detected more frequently or have exceeded an MCL from 2007 through 2011.

\section{Arsenic}

Arsenic concentrations entering the site from Hickory Hollow and Grantham Creeks are higher than concentrations in some onsite wells and are higher than concentrations in Half Moon Creek leaving the site (Figure 8). This indicates a natural or offsite contribution of arsenic. The highest concentrations are around SGZ in the Alluvial Aquifer, with the highest result $(0.015 \mathrm{mg} / \mathrm{L})$ in well SA1-3-H, which exceeds the $0.010 \mathrm{mg} / \mathrm{L}$ MCL. Arsenic concentrations are also elevated in Local Aquifer wells, and results from Aquifer 3 are roughly 2 orders of magnitude lower and at levels equivalent to those in the creeks (Figure 8). Arsenic is not analyzed in samples from the two remaining Aquifer 3 wells or from onsite wells screened in the other aquifers. The CPT results (Tables 1-5) showed that arsenic was detected in four water samples in SA1, one water sample in SA2, six soil samples and one water sample in SA3, and one soil sample in SA4. No arsenic concentrations exceeded the MCL in samples collected during the 1993 remedial investigation.

\section{Barium}

Barium concentrations are highest in the Local Aquifer, with the highest result $(2.6 \mathrm{mg} / \mathrm{L})$ in well SA4-5-L southwest of SGZ, which exceeded the $2 \mathrm{mg} / \mathrm{L} \mathrm{MCL}$. The second highest result $(0.89 \mathrm{mg} / \mathrm{L})$ is in well SA2-2-L near the REECo Disposal Pits in SA2 (Figure 9). Barium is also present in the Alluvial Aquifer and in Aquifer 3. Barium is not analyzed in samples from the two remaining Aquifer 3 wells or in onsite wells screened in the other aquifers. The CPT results (Tables 1-5) showed barium above the MCL in two water samples in SA1, two water samples in SA3, and one sample each in SA2 and SA4 during the 1993 remedial investigation. Barium was also detected in two additional water samples in SA1, one soil sample in SA2, two soil samples in SA3, one additional water sample in SA4, and one soil sample in SA5.

\section{Chromium}

Chromium was detected in one Alluvial Aquifer well (SA1-3-H), two Local Aquifer wells (SA2-2-L and SA4-5-L), in REECo Pit (A), and in Aquifer 3 well HM-3. The result from HM-3 (0.12 mg/L) just exceeded the $0.01 \mathrm{mg} / \mathrm{L}$ MCL (Figure 10). Chromium is not analyzed in samples from the two remaining Aquifer 3 wells or in the onsite wells screened in the other aquifers. The CPT results (Tables 1-5) showed that chromium was detected in all of the soil samples and exceeded the MCL in all of the water samples in SA1. In SA2, chromium was 
detected in six soil samples, and concentrations in two of the water samples exceeded the MCL. In SA4, chromium was detected in one soil sample, and concentrations exceeded the MCL in three water samples. In SA5 chromium was detected in three soil samples and one water sample collected during the 1993 remedial investigation.

\section{Lead}

Lead either is not detected or is detected at levels roughly 2 to 3 orders of magnitude lower than the MCL of $0.015 \mathrm{mg} / \mathrm{L}$. However, concentrations exceeded the MCL in samples collected in 2007. The highest concentrations are in the Local Aquifer wells SA2-2-L $(0.0068 \mathrm{mg} / \mathrm{L})$ and SA4-5-L (0.0055 mg/L) (Figure 11). The CPT results (Tables 1-5) show that lead was detected in four soil samples and concentrations exceeded the MCL in three water samples in SA4. Lead also was detected in eight soil samples and concentrations exceeded the MCL in two water samples from SA2.

\section{Zinc}

Zinc is detected at low levels in a few Alluvial Aquifer wells and in well HM-3. Higher concentrations are detected in the REECo Disposal Pits, the Beaver Pond, and the Local Aquifer, with the highest result in well SA4-5-L $(0.18 \mathrm{mg} / \mathrm{L})$ (Figure 12). Zinc was not detected in any of the CPT samples during the 1993 remedial investigation.

\section{VOCs}

The current volatile organic constituents onsite are TCE and its degradation products - cis- and trans-1,2-DCE and vinyl chloride. These compounds are classified as dense nonaqueous-phase liquids (known as DNAPLs) with specific gravities greater than that of water. These compounds could therefore sink to the bottom of the aquifer if they are present at concentrations that exceed their limits of solubility. No separate phase DNAPL has been identified in the Alluvial Aquifer, though this is dependent on the proximity of monitoring wells to possible DNAPL source locations. Without knowing the volume of TCE used at the site, where it was stored, where or how it was disposed of, or where it was used (and likely spilled), the possibility of one or more DNAPL source locations at the site cannot be ruled out. Currently, only the Alluvial Aquifer is monitored for VOCs. During the 1993 remedial investigation, TCE and both isomers of 1,2-DCE were detected in one water sample from SA1, and concentrations of both 1,2-DCE isomers exceeded the MCL in another sample from SA1 (Table 1). Perchloroethene (PCE) was detected at the detection limit in SA2 (Table 2).

If conditions are favorable, TCE will degrade by reductive dehalogenation to the cis and trans isomers of 1,2-DCE, which will degrade to vinyl chloride, then to ethene, and finally to carbon dioxide and water. Reducing conditions and an electron donor are required for this degradation pathway to proceed as well as the microbe Dehalococcoides mccartyii. The oxidation-reduction potential and dissolved oxygen are not currently measured as part of the sampling protocol, so reducing conditions cannot be confirmed. It is recommended that these field measurements be added to the annual sampling. An indication that this degradation is proceeding would be a decrease in the TCE concentrations combined with the presence of the degradation products. TCE levels have been decreasing in site groundwater, and 1,2-DCE isomers and vinyl chloride are also detected in groundwater. 
TCE was detected in five of the Alluvial Aquifer wells, with the highest concentration in HMH-5R (100 micrograms per liter $[\mu \mathrm{g} / \mathrm{L}]$ ), which exceeds the MCL of $5 \mu \mathrm{g} / \mathrm{L}$ (Figure 13). Although cis-1,2-DCE was detected in seven of the Alluvial Aquifer wells, the highest concentration detected on the site was $62 \mu \mathrm{g} / \mathrm{L}$ in well SA1-3-H (Figure 14), which is below the MCL of $70 \mu \mathrm{g} / \mathrm{L}$. The trans-1,2-DCE isomer was detected in six of the Alluvial Aquifer wells on the site. The highest concentration was $29 \mu \mathrm{g} / \mathrm{L}$ (in well SA1-3-H) (Figure 15), which is below the MCL of $100 \mu \mathrm{g} / \mathrm{L}$. Vinyl chloride is only detected in three of the Alluvial Aquifer wells, with the highest concentration in SA1-3-H $(1.5 \mu \mathrm{g} / \mathrm{L})$ (Figure 16). Concentrations of vinyl chloride do not exceed the $2 \mu \mathrm{g} / \mathrm{L}$ MCL in any of the site wells.

TCE degradation products are detected in wells located upgradient from the highest detected TCE concentration, and TCE either is not detected or is present in lower concentration in these wells. This could indicate an upgradient TCE source that is not currently known and that is degrading and contributing to the results in these wells, or it is possible that historically conditions in these wells were reducing, and the TCE degraded quickly. It is recommended that historical (pre-2007) VOC data be re-evaluated to better understand the TCE contamination onsite.

\section{Radionuclides}

The only radionuclide that is currently detected in site waters is tritium, which was brought to surface during post-shot drilling activities. Tritium is detected in the Alluvial Aquifer, in surface water locations, and in one Local Aquifer well (HM-L). The highest concentrations are in wells SA1-1-H (4,600 pCi/L) and HMH-5R (1,310 pCi/L) (Figure 17), which are both well below the MCL of 20,000 pCi/L. Tritium was detected in one water sample in SA3 and in one water sample in SA4 during the 1993 remedial investigation (Table 3 and Table 4). 


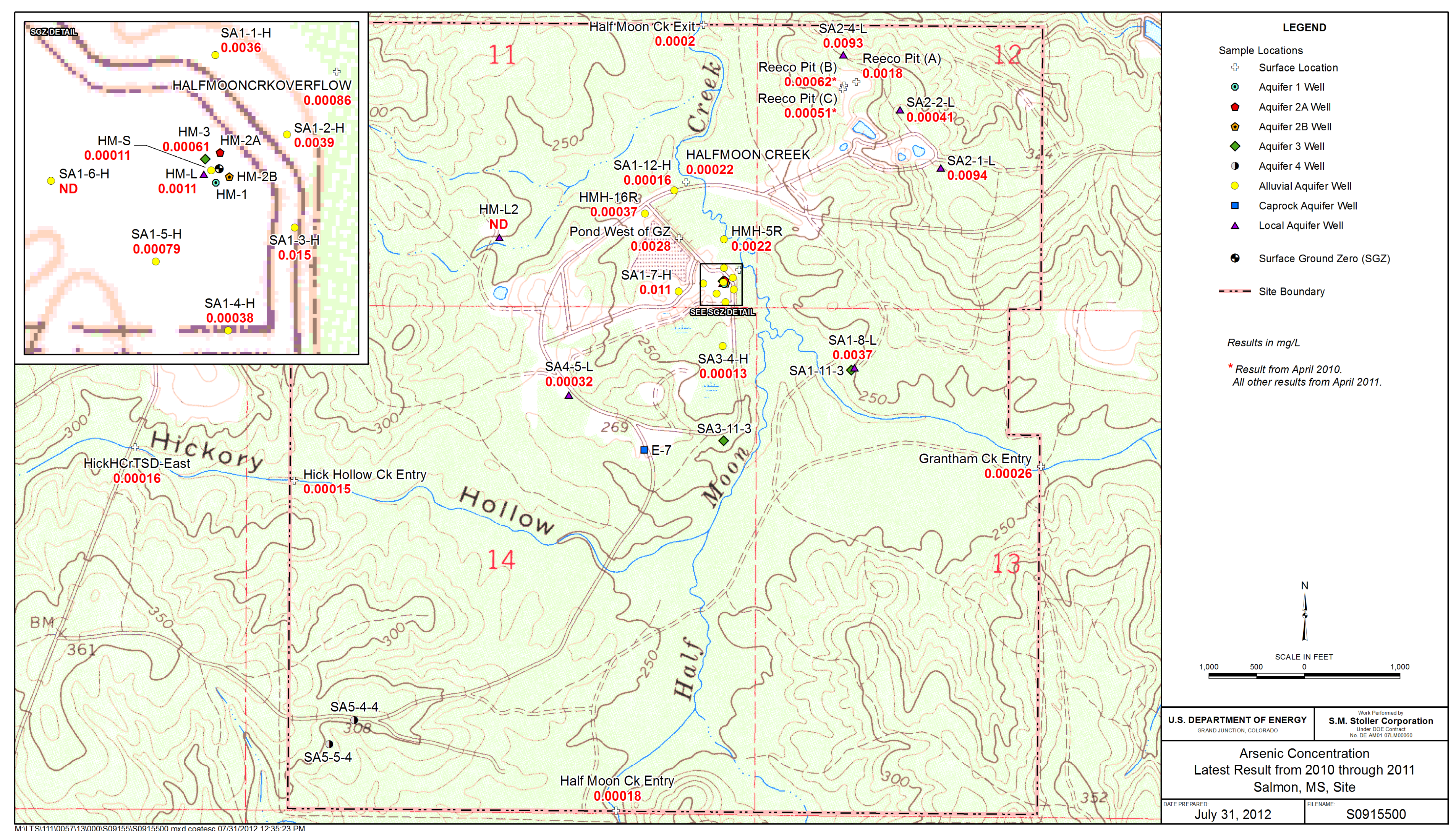

Figure 8. Current Arsenic Concentrations at the Salmon Site 


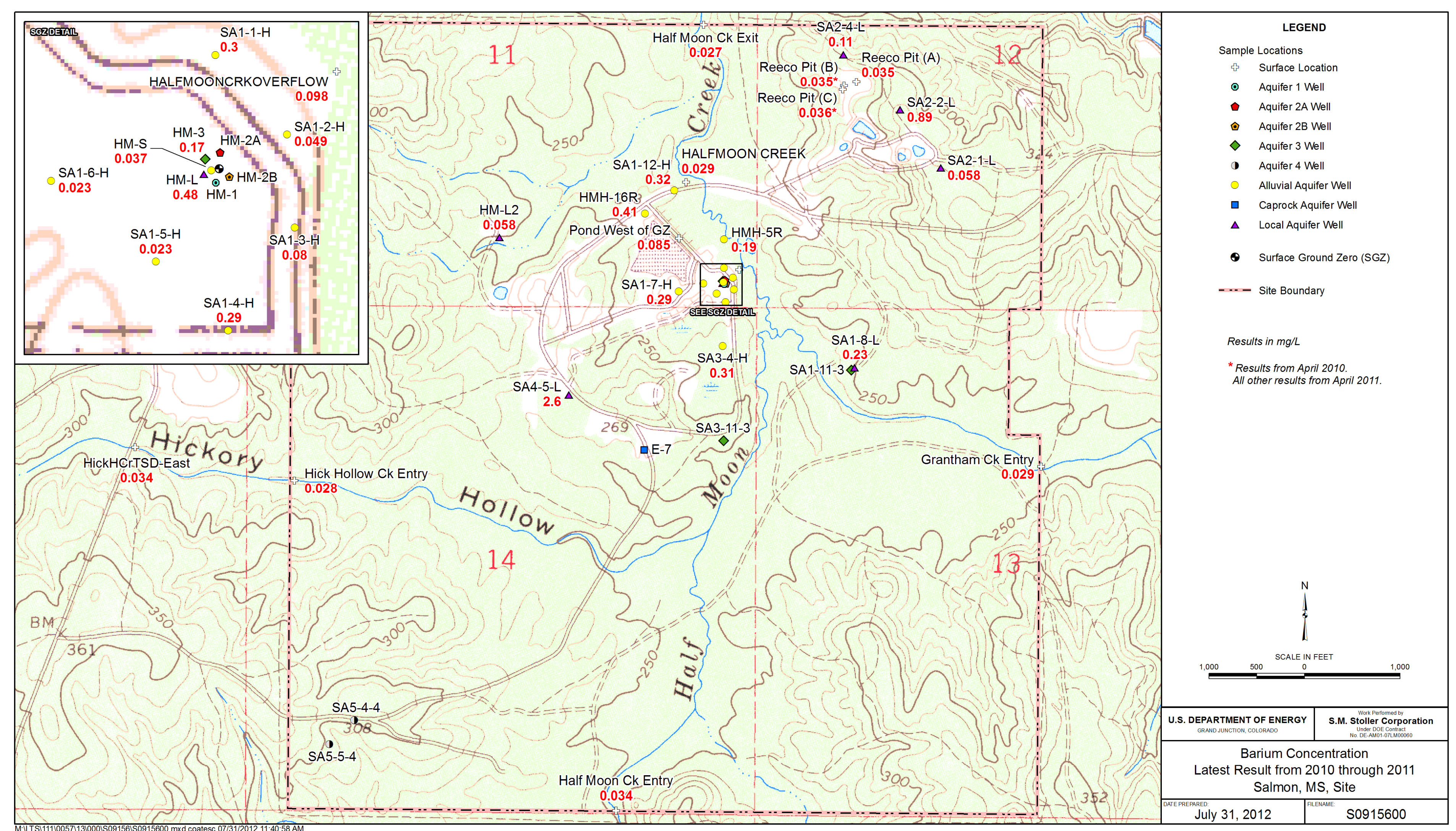

Figure 9. Current Barium Concentrations at the Salmon Site 


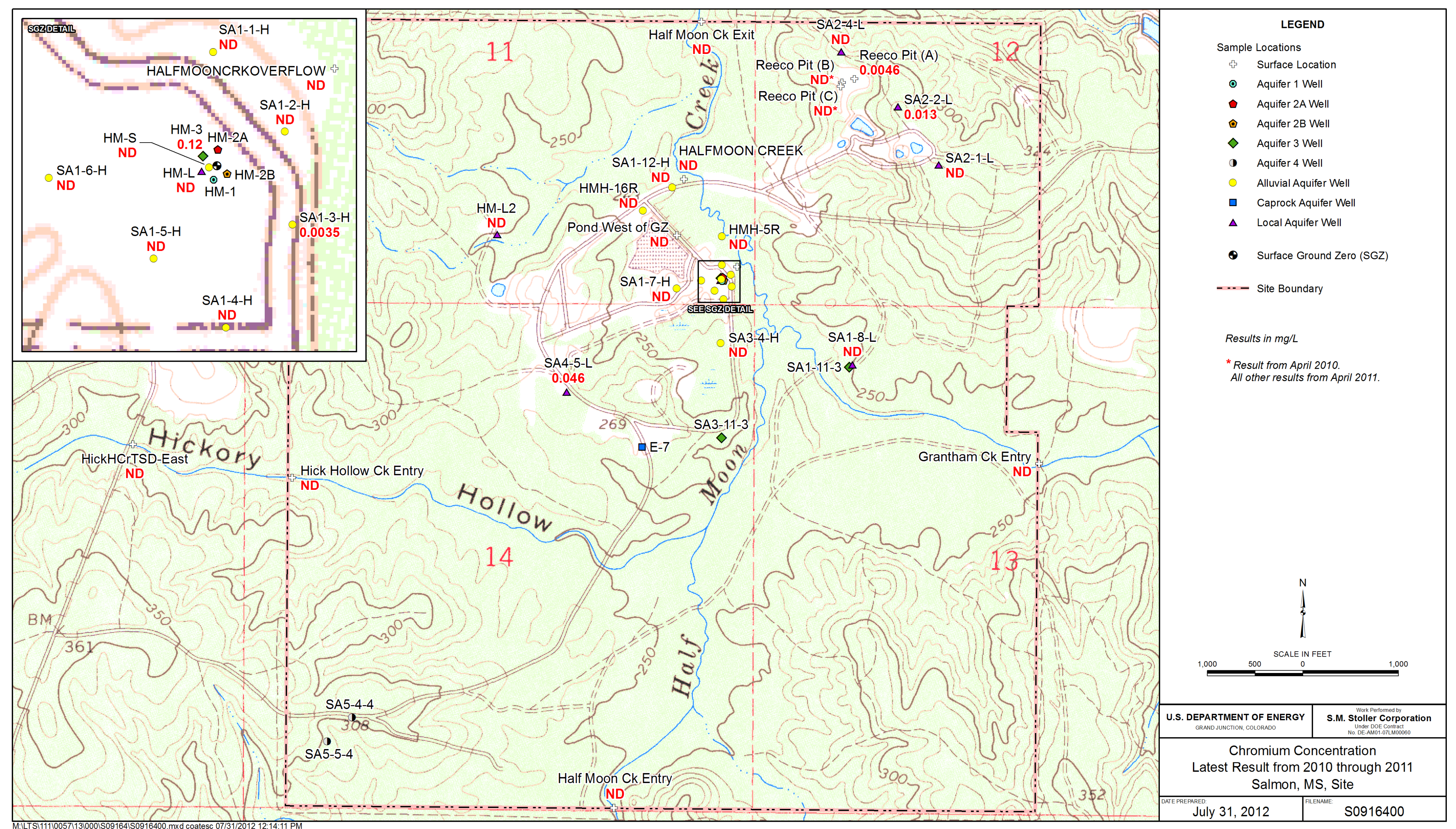

Figure 10. Current Chromium Concentrations at the Salmon Site 


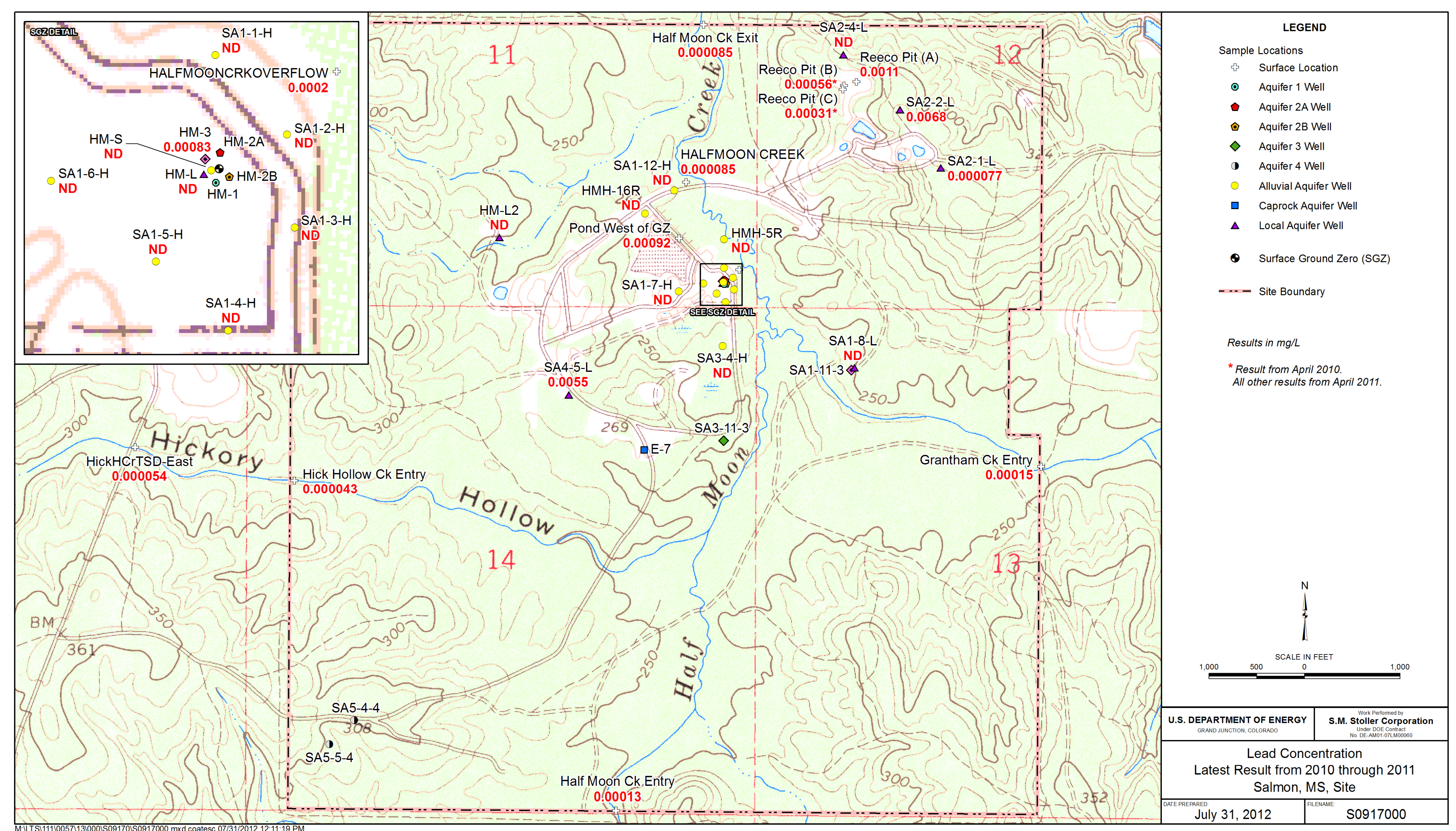

Figure 11. Current Lead Concentrations at the Salmon Site 


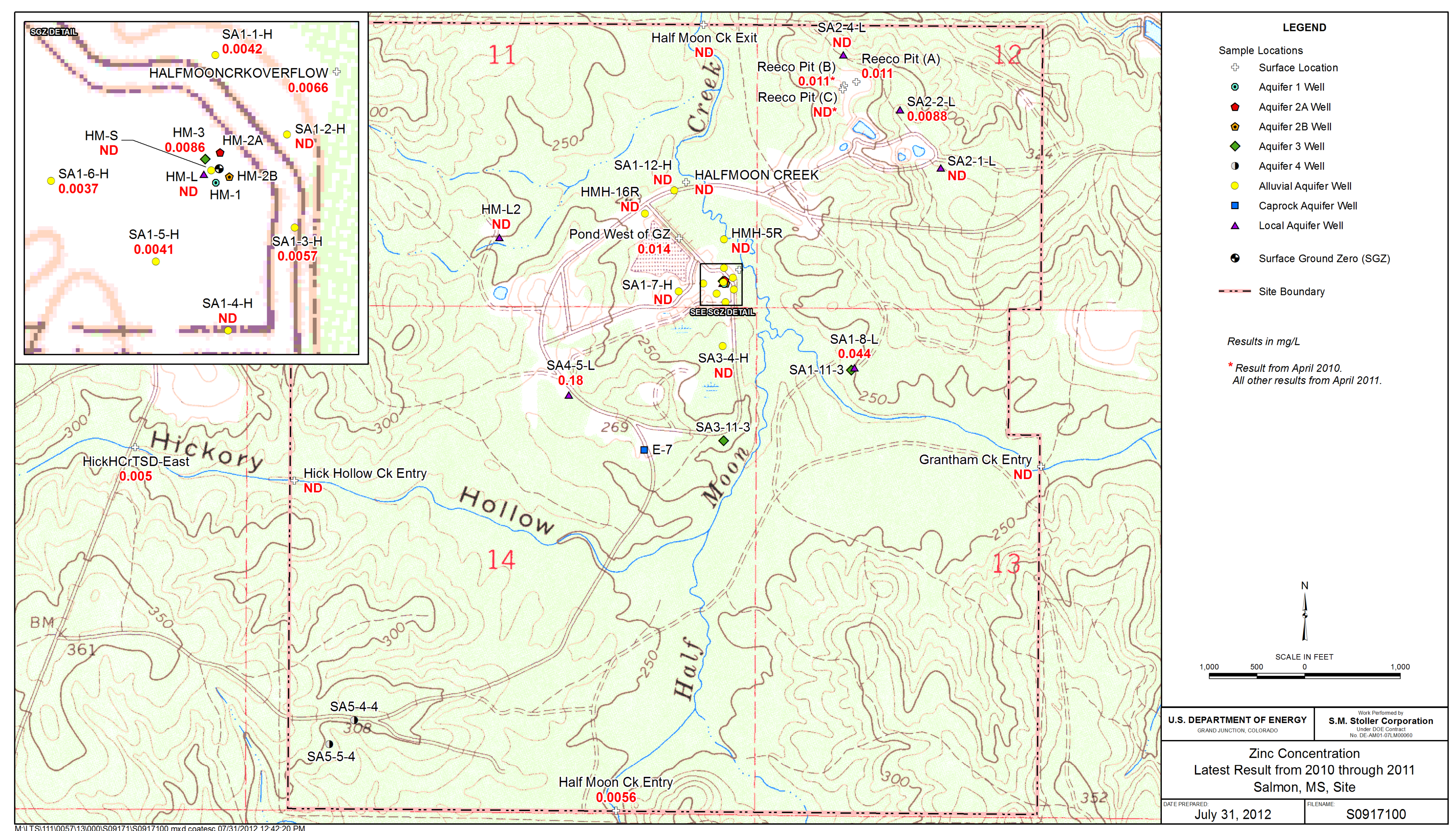

Figure 12. Current Zinc Concentrations at the Salmon Site 


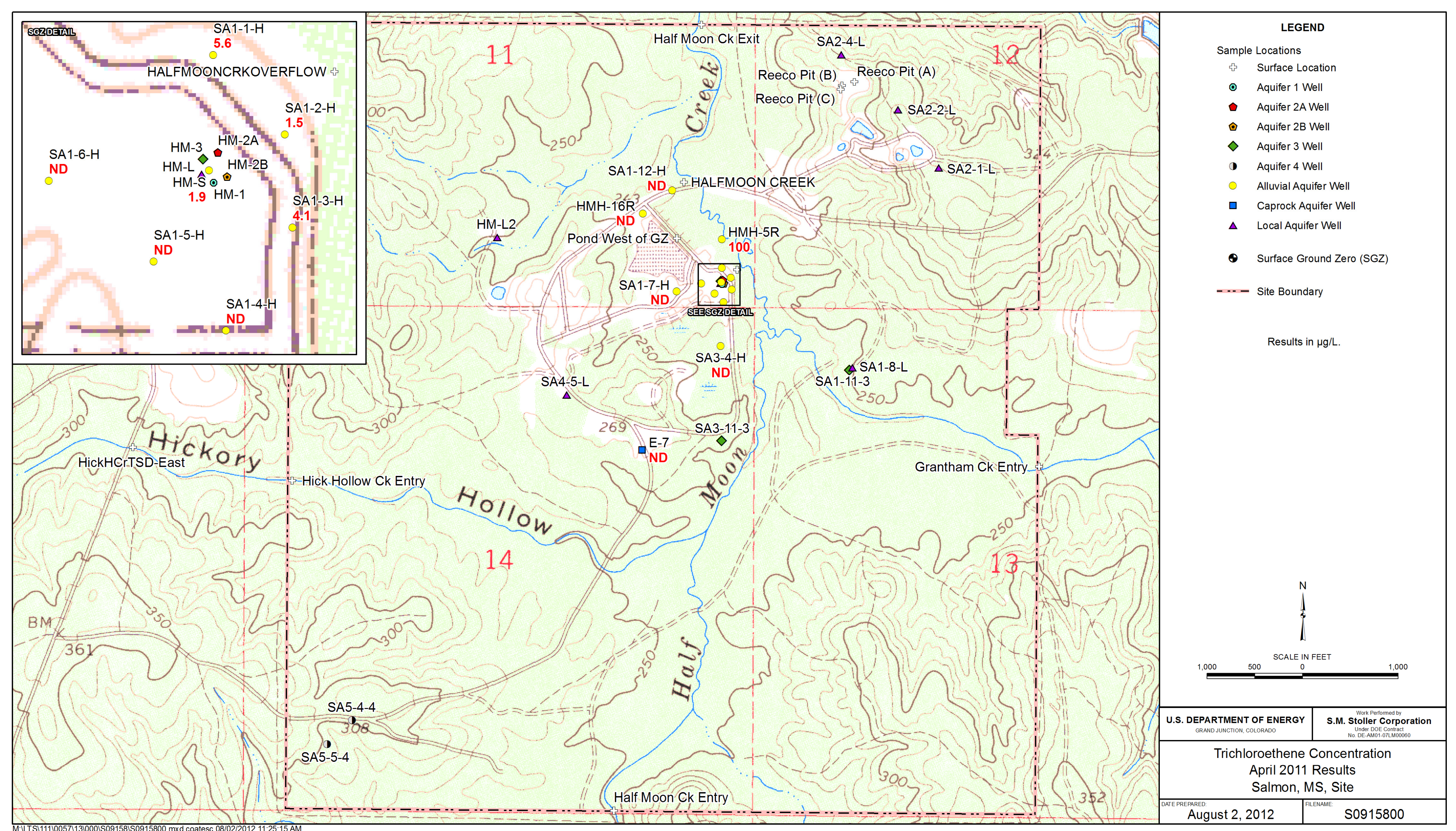

Figure 13. Current Trichloroethene Concentrations at the Salmon Site 


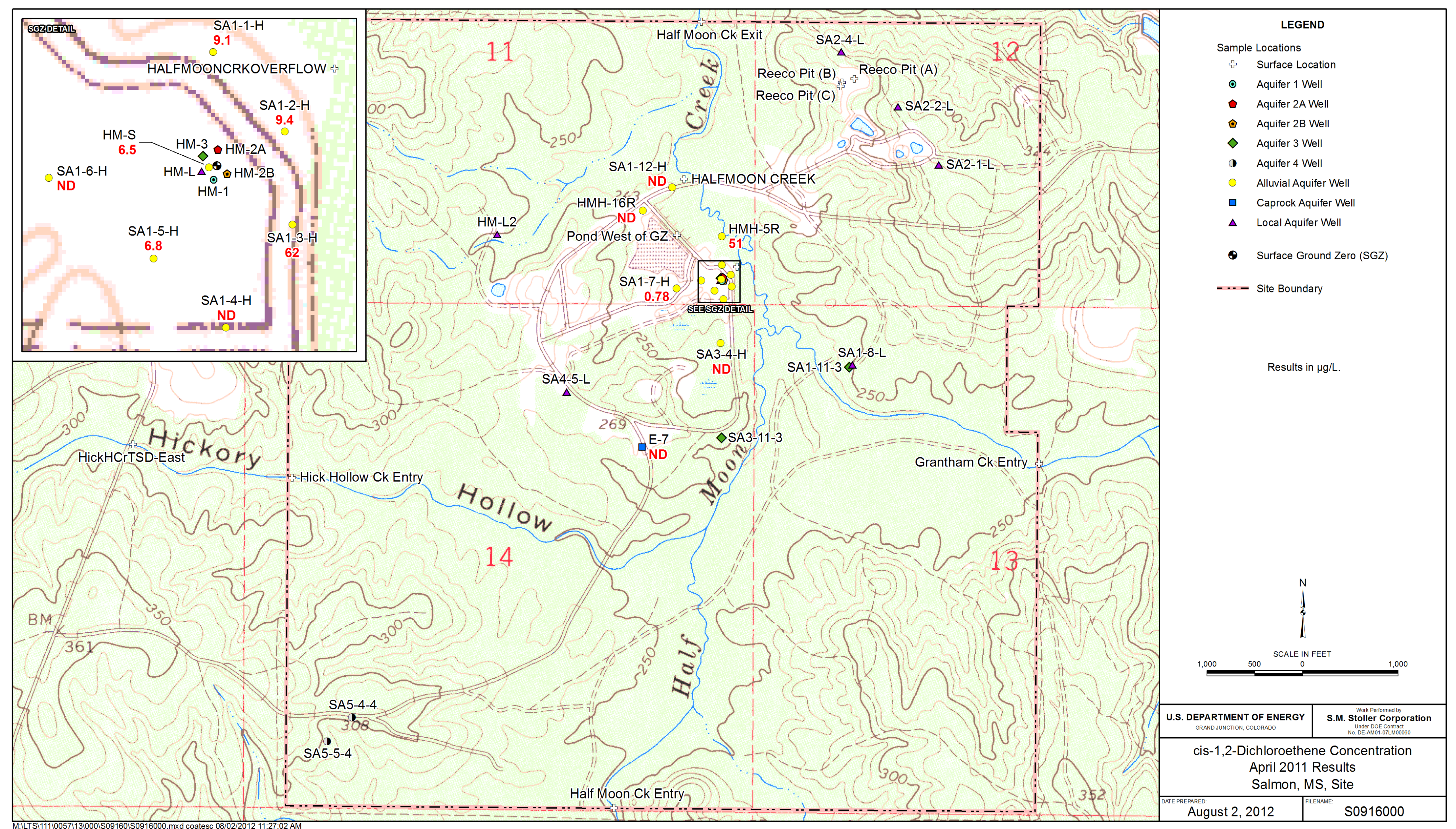

Figure 14. Current cis-1,2-Dichloroethene Concentrations at the Salmon Site 


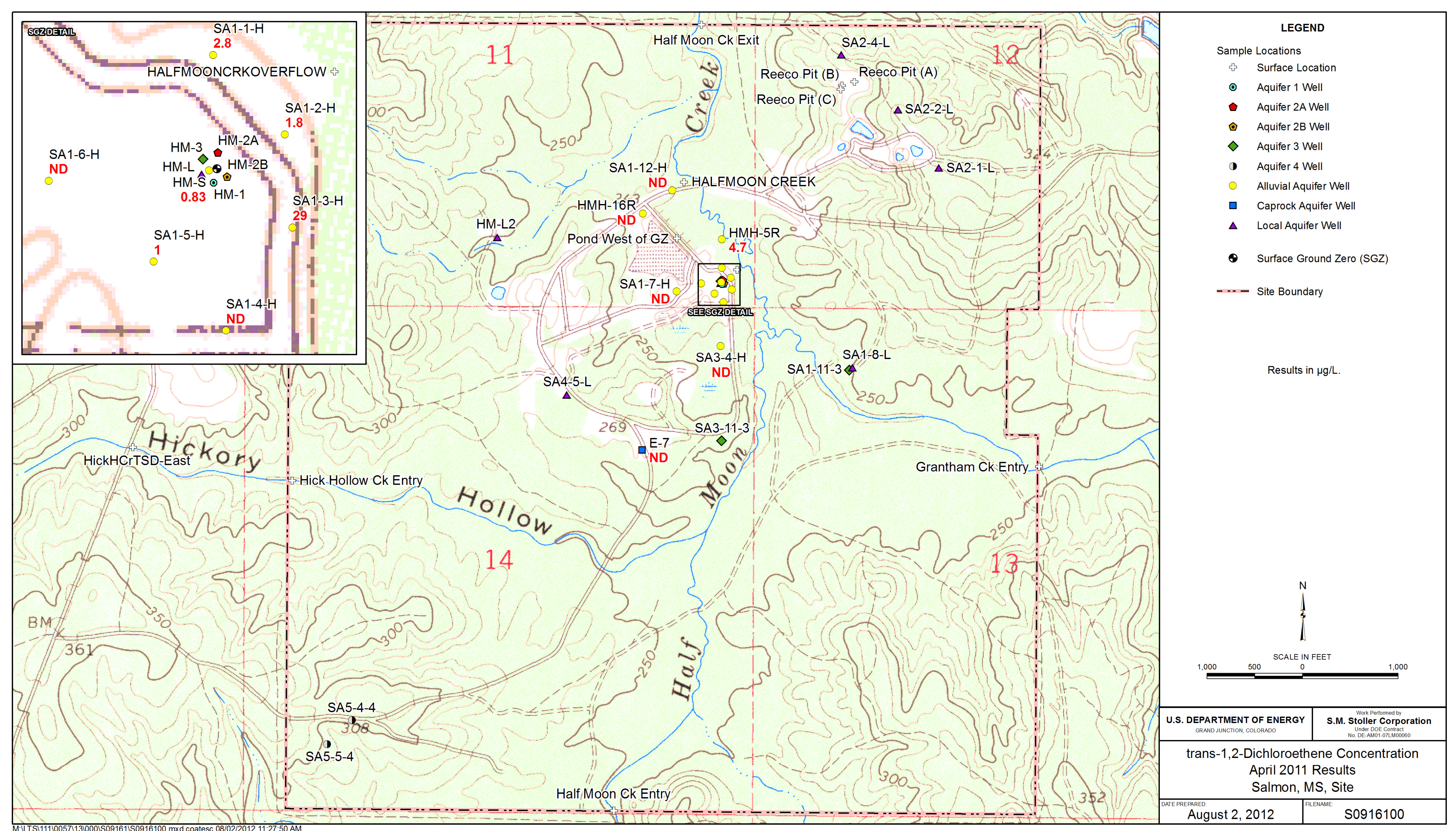

Figure 15. Current trans-1,2-Dichloroethene Concentrations at the Salmon Site 


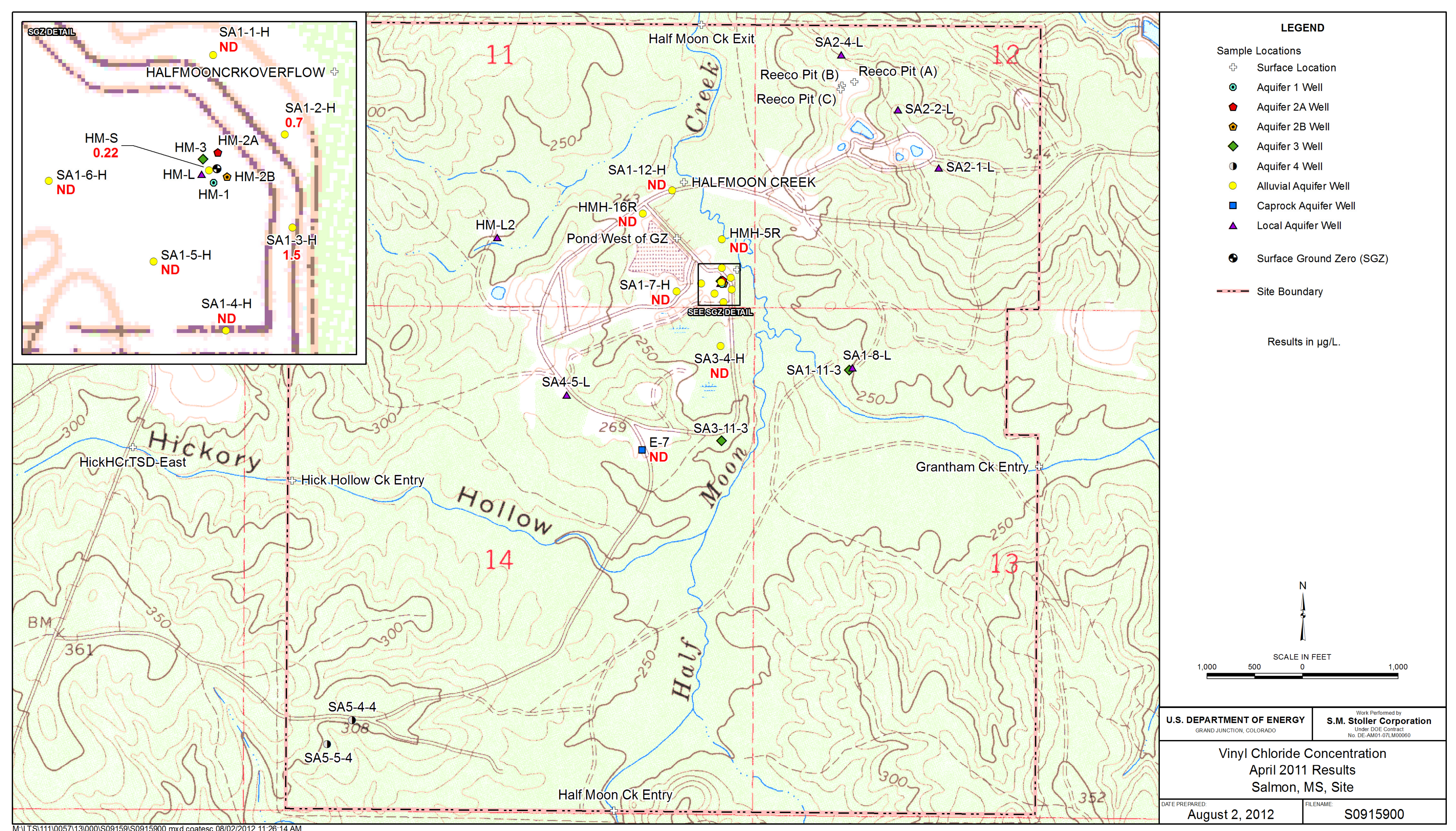

Figure 16. Current Vinyl Chloride Concentrations at the Salmon Site 


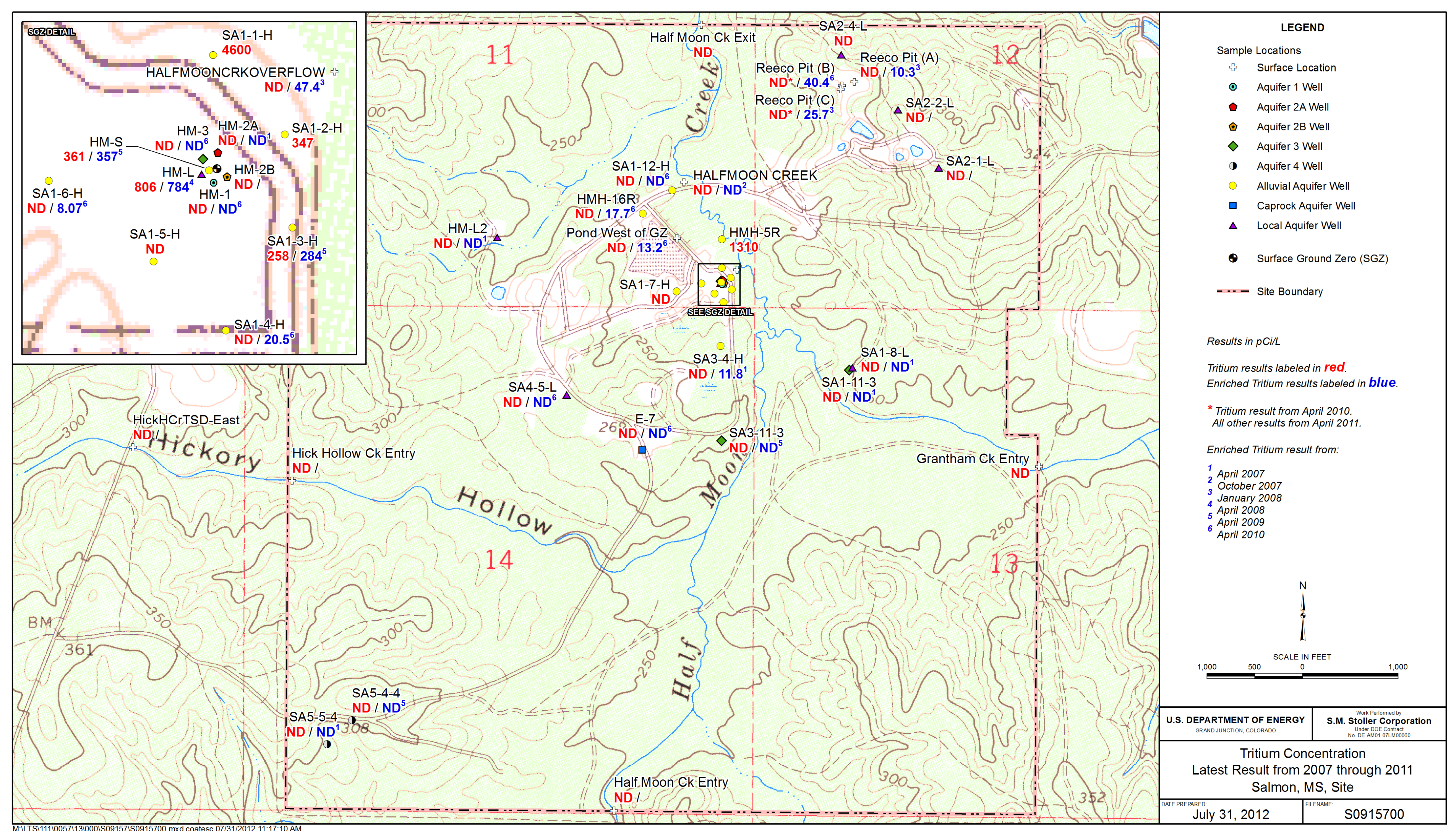

Figure 17. Current Tritium Concentrations at the Salmon Site 


\subsubsection{Potential Contamination from Aquifer 5}

The radioactively contaminated water injected into Aquifer 5 is a potential source of future contamination; however, it is not likely that water from Aquifer 5 could migrate upward to Aquifer 4. Aquifer 5 is confined on the top and bottom by thick beds of clay. Two Aquifer 4 wells monitor this area, and tritium has not been detected (Figure 18).
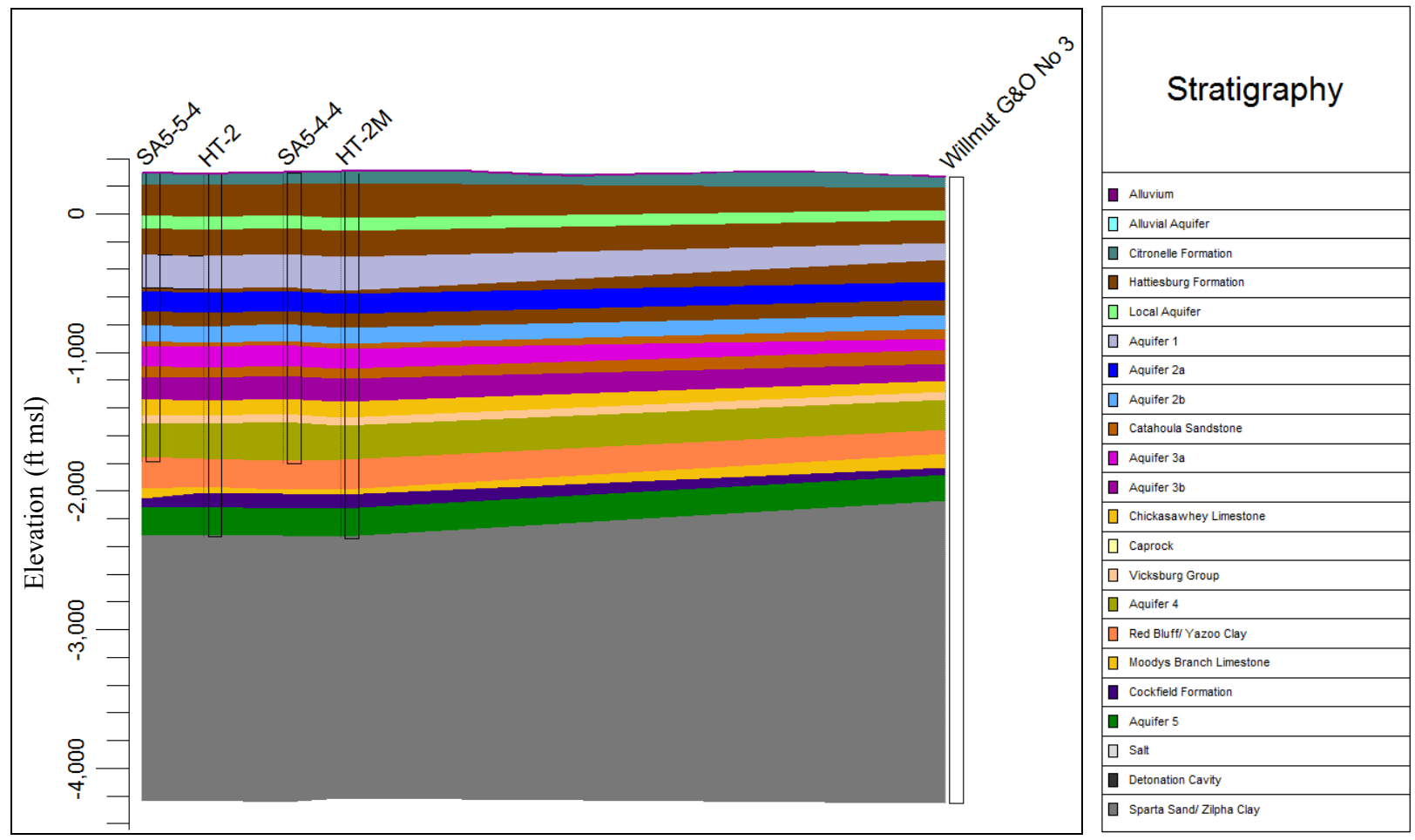

Abbreviations:

$\mathrm{msl}=$ mean sea level

Figure 18. Aquifer 4 and Five Wells and Stratigraphic Section

\subsubsection{Potential Contamination from the Shot Cavity}

The Station 1-A Post-Shot Hole No. 1 and the Post-Shot Hole No. 2, both of which entered the test cavity, have been plugged to the surface with concrete (DOE 1972). Before the Station 1-A casing was plugged, approximately 10,770 cubic yards of contaminated soil and $1,305,000$ gallons of contaminated fluids and freshwater were disposed of in the cavity. From the recorded total volume of material, it was calculated that the top of the cavity fill would be about $2,705 \mathrm{ft}$ below ground surface. The cavity dimensions used in the calculation and the accuracy of the recorded volumes of material were confirmed when the cavity fill was tagged at 2,704 $\mathrm{ft}$ with a logging tool. The above volumes are estimated to occupy approximately 57 percent of the available cavity volume (Figure 19). A concrete slab approximately $6 \mathrm{ft} \times 14 \mathrm{ft} \times 6$ inches thick was poured to cover the top of the casing of Station 1-A and Post-Shot Hole No. 1, as well as the Post-Shot No. 1 Mouse Hole (DOE 1973). 
Exploration drillback and geophysical analysis indicates that discontinuous microfractures may exist as far as $350 \mathrm{ft}$ from the shot point, but beyond $200 \mathrm{ft}$ the rock is not generally

microfractured (Rawson 1965). Major deformational features do not exist beyond $65 \mathrm{ft}$ from the shot point (Gardner and Downs 1971).

No underground cavity is permanently stable; voids tend to close under lithologic pressure. The most probable case is for the cavity to close very slowly by plastic flow of halite. Considerable complexity is imposed by the stresses inherent in the Tatum Dome, which had an upward flow component, and thrust through sediments imposing local stress and strain. The method described by Hakala (1970) was used to determine that, for the test cavity at the Gnome-Coach, New Mexico, Site, a cavity with a spherical radius in a bedded salt formation might collapse to form a chimney about $290 \mathrm{ft}$ upward from the working point. Extension of this determination to the similar cavity dimension but greater depth at the Salmon site indicates safe physical conditions. Neither a chimney, formed upon cavity collapse, nor very slow plastic flow closure would be evident at the surface. Mature domes such as Tatum, with a long history of repeated vertical thrust, should have predominant tight, vertical banding (Gardner and Downs 1971).

The cavity is centered at $2,715 \mathrm{ft}$ below ground surface, and the top of the cavity at the STA-1A entry is 2,660 ft below ground surface and approximately 1,200 $\mathrm{ft}$ below the top of the salt. The high-level radioactivity is confined to the recrystallized melt at the bottom of the cavity, and the cavity is surrounded by salt on all sides (Figure 19). Contaminant migration through the salt is highly unlikely, since there is no native water within the salt dome and therefore no transport mechanism. The shortest distance for horizontal movement of contaminants from the shot cavity through the salt dome is approximately 1,100 to 1,200 $\mathrm{ft}$ (Figure 20). Given that the geologic pressures and plastic flow are pushing in toward the cavity and the vertical structure of the salt, any movement of contaminants would likely be upward. The likely pathway would be along the wells that entered the cavity. For this scenario to happen the cement plugs or the well casings would have to become degraded, and any force that moves contaminants would need to exert sufficient pressure to push any water or gases to the entry point of the wells in the cavity and then through 1,200 ft of salt and $600 \mathrm{ft}$ of cap rock (Figure 19). Figure 21 is a schematic that shows the relationship of the dome, shot cavity, and SGZ well cluster. The vertical gradients interpreted from water levels in these wells indicate that if migration of contamination from the shot cavity were to occur, it most likely be detected in Aquifer $2 \mathrm{~b}$ or lower. 


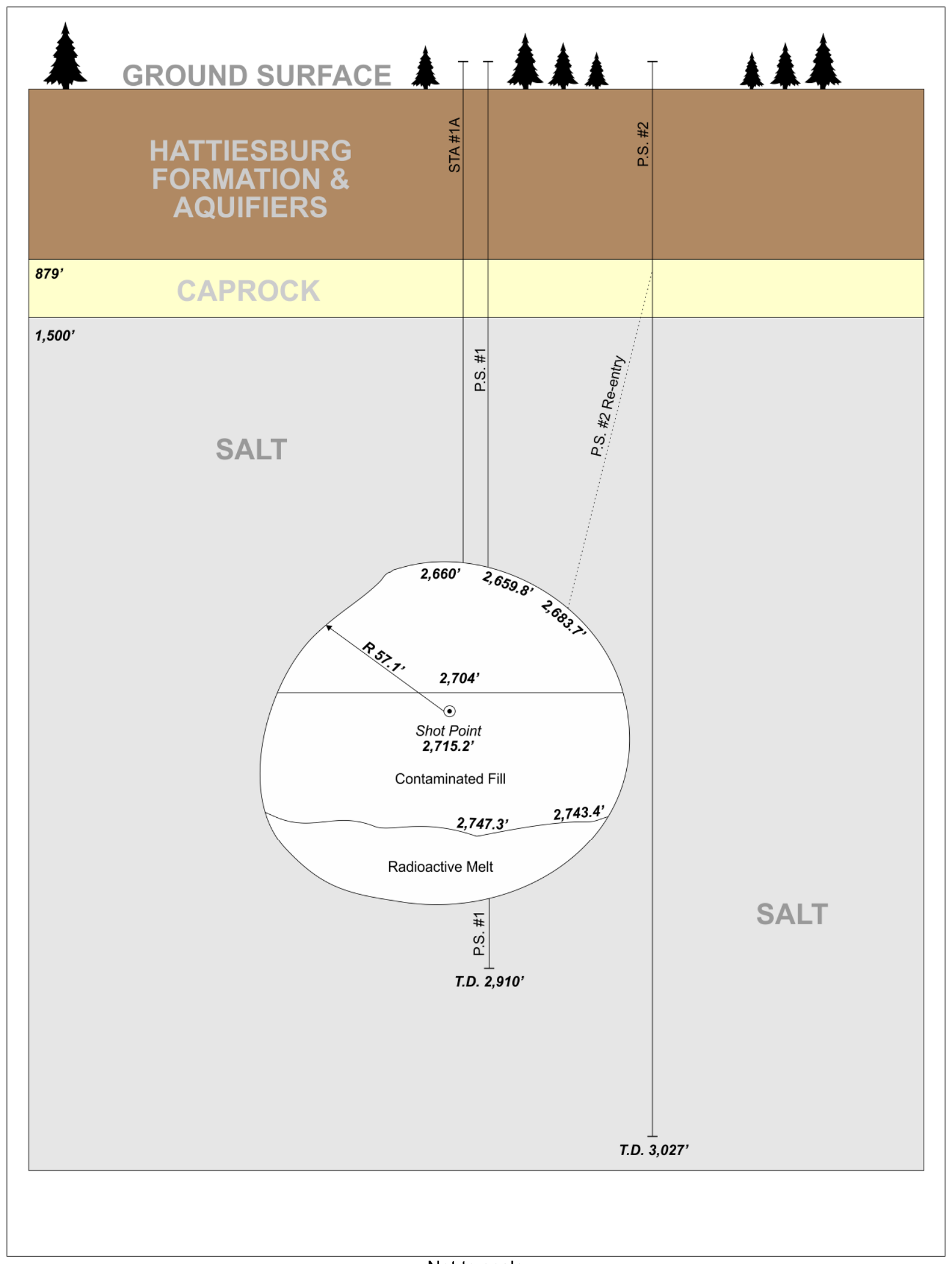

Not to scale

Figure 19. Cross-Sectional Depiction of the Shot Cavity 


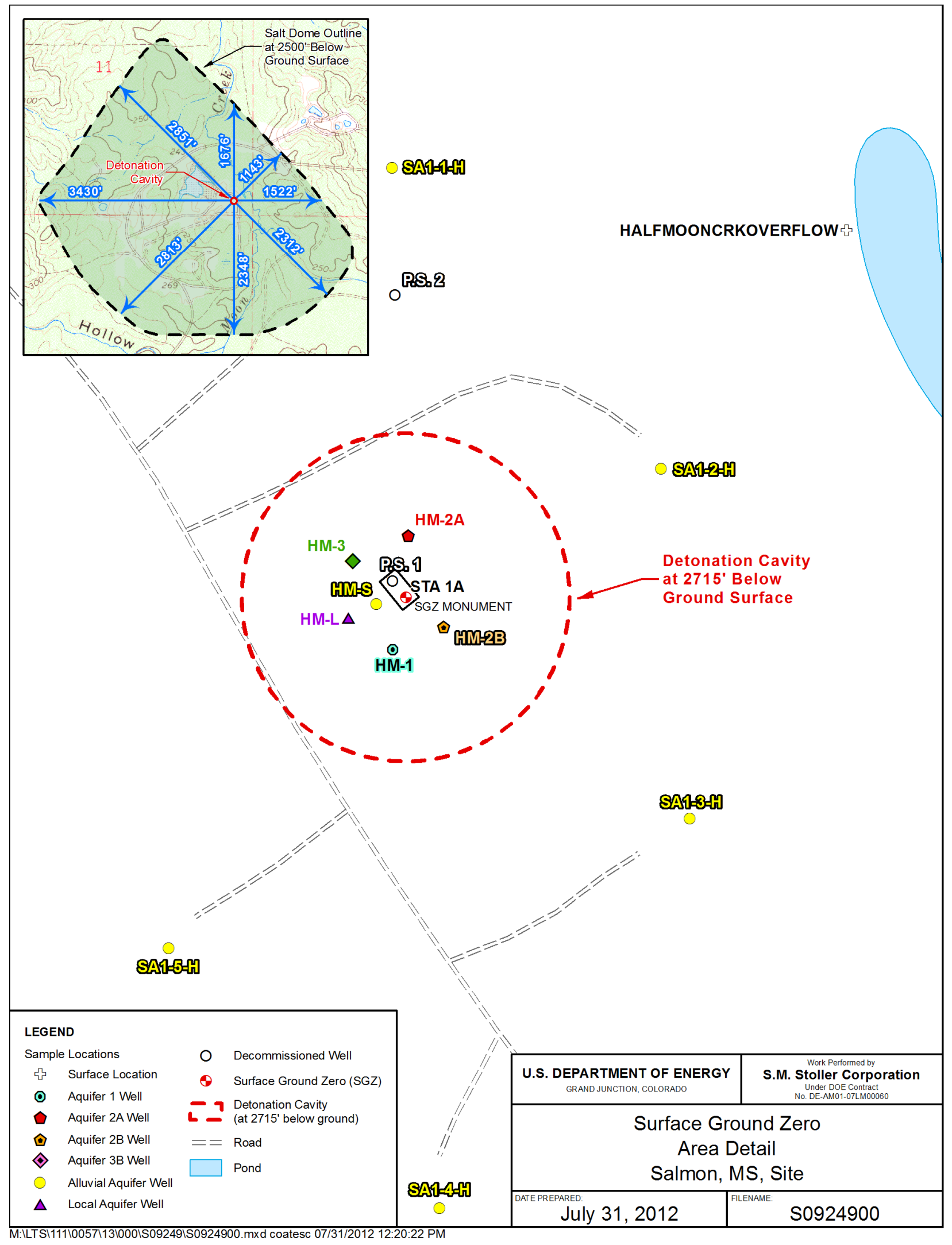

Figure 20. Location of the Shot Cavity 


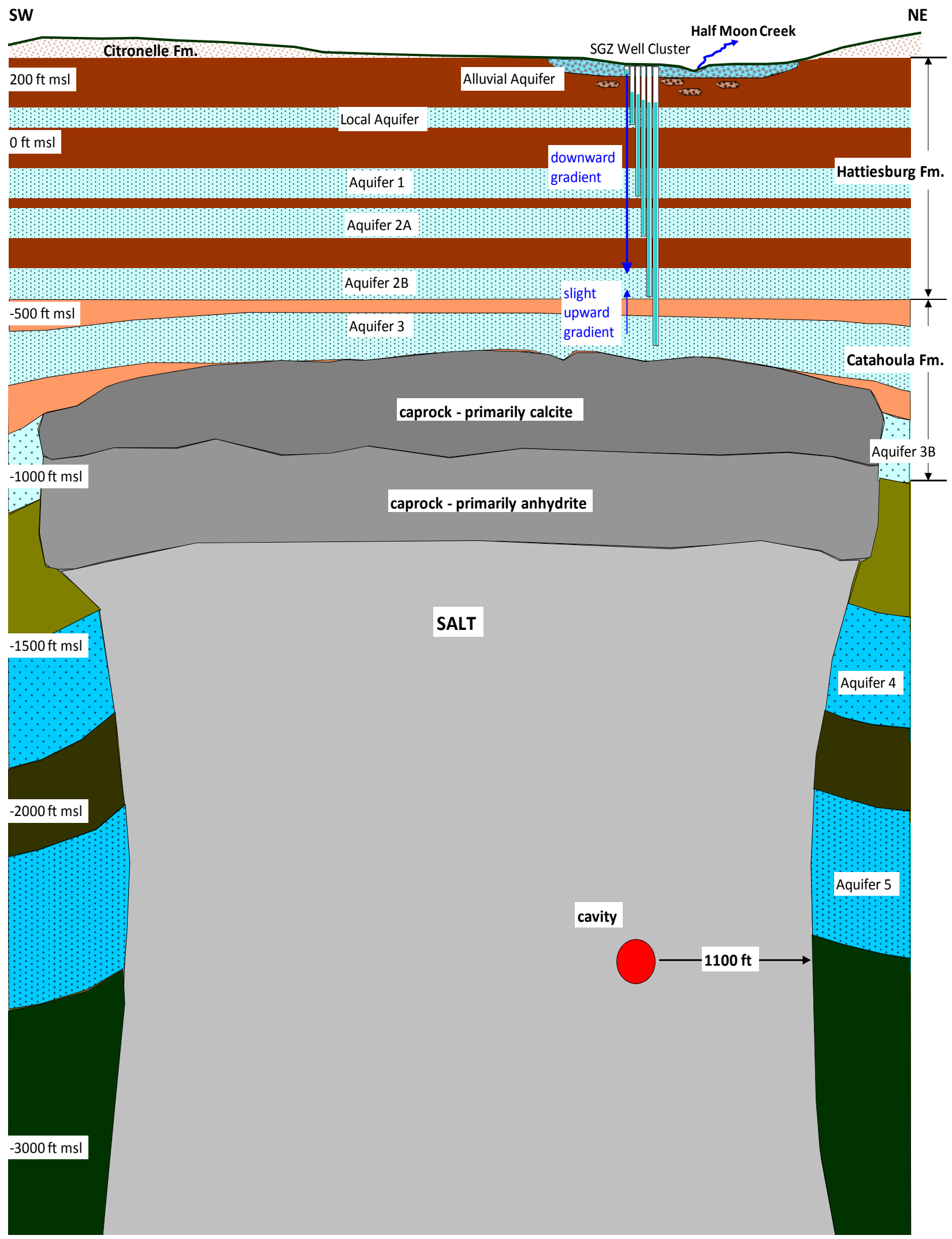

Figure 21. Conceptual Model of the Relationship of the Dome, Shot Cavity, and SGZ Well Cluster 


\section{Radionuclides}

If contamination reaches the surface from the shot cavity, then radionuclides typical of fission reactions would be detectable. Site water is currently analyzed for tritium and 19 other radionuclides, both naturally occurring and fission-related. To date, except for tritium, no radionuclides have been detected during annual sampling. The tritium detected results from surface contamination rather than migration from the cavity. The isotopes that could indicate release from the cavity are listed in Table 6. This list was obtained from the Nevada Test Site Radionuclide Inventory 1951-1992 (Bowen et al. 2001). The radionuclide inventory includes long-lived radioactive species produced by or remaining after underground nuclear explosions at the Nevada Test Site (now known as the Nevada National Security Site) during the period 1951 to 1992. The inventory represents a starting point for the estimation of radionuclides available for dispersal away from nuclear test sites. Not all radionuclides are equally available for transport; some are bound in the recrystallized melt in the test cavity. The Salmon site differs from the Nevada National Security Site in that the detonation occurred in a salt dome where no water is present to transport radionuclides through the salt to the groundwater; however, the radionuclide inventory in the Salmon cavity should be similar.

The radioisotopes that are currently analyzed by gamma spectroscopy are actinium-228, americium-241, antimony-125, cerium-144, cesium-134, cesium-137, cobalt-60, europium-152, europium-154, europium-155, lead-212, potassium-40, promethium-144, promethium-146, ruthenium-106, thorium-234, uranium-235, uranium-238, and yttrium-88.

Tritium is also analyzed in all site samples, and although the concentrations detected in water are from the surface contamination, tritium could also be an indicator of contaminant migration from the cavity. The current tritium concentrations onsite will continue to decrease by dilution and radioactive decay and will eventually disappear. 
Table 6. Candidate Radionuclides for Inclusion into Source-Term Inventory

\begin{tabular}{|c|c|c|c|c|}
\hline Element & Nuclide & $\begin{array}{l}\begin{array}{l}\text { Half-life } \\
\text { (years) }^{\mathrm{a}}\end{array} \\
\end{array}$ & $\begin{array}{c}\text { Emission } \\
\text { Type }\end{array}$ & Main Source (FP = fission product) \\
\hline Hydrogen & ${ }^{3} \mathrm{H}$ & 12.32 & beta & device component: ${ }^{6} \mathrm{LI}$, \\
\hline Carbon & ${ }^{14} \mathrm{C}$ & $5.715 \times 10^{3}$ & beta & ${ }^{14} \mathrm{~N},{ }^{13} \mathrm{C},{ }^{17} \mathrm{O}$ \\
\hline Aluminum & ${ }^{26} \mathrm{Al}$ & $7.1 \times 10^{5}$ & beta & ${ }^{27} \mathrm{Al}$ \\
\hline Chlorine & ${ }^{36} \mathrm{Cl}$ & $3.01 \times 10^{5}$ & beta & ${ }^{35} \mathrm{Cl},{ }^{39} \mathrm{~K}$ \\
\hline Argon & ${ }^{39} \mathrm{Ar}$ & 269 & & ${ }^{39} \mathrm{~K},{ }^{38} \mathrm{Ar}$ \\
\hline Potassium & ${ }^{40} \mathrm{~K}$ & $1.27 \times 10^{9}$ & & natural \\
\hline Calcium & ${ }^{41} \mathrm{Ca}$ & $1.03 \times 10^{5}$ & beta & ${ }^{40} \mathrm{Ca}$ \\
\hline \multirow{2}{*}{ Nickel } & ${ }^{59} \mathrm{Ni}$ & $7.6 \times 10^{4}$ & beta & ${ }^{58} \mathrm{Ni}$ \\
\hline & ${ }^{63} \mathrm{Ni}$ & 100 & beta & ${ }^{62} \mathrm{Ni},{ }^{64} \mathrm{Ni},{ }^{63} \mathrm{Cu}$ \\
\hline Krypton & ${ }^{85} \mathrm{Kr}$ & 10.76 & beta & $\mathrm{FP},{ }^{84} \mathrm{Kr}$ \\
\hline Strontium & ${ }^{90} \mathrm{Sr}$ & 28.78 & beta & FP \\
\hline Zirconium & ${ }^{93} \mathrm{Zr}$ & $1.5 \times 10^{6}$ & beta & $\mathrm{FP},{ }^{92} \mathrm{Zr},{ }^{94} \mathrm{Zr}$ \\
\hline \multirow{2}{*}{ Niobium } & ${ }^{93 \mathrm{~m}} \mathrm{Nb}$ & 16.1 & beta & ${ }^{93} \mathrm{Nb}$ \\
\hline & ${ }^{94} \mathrm{Nb}$ & $2.0 \times 10^{4}$ & beta & FP, ${ }^{93} \mathrm{Nb}$ \\
\hline Technetium & ${ }^{99} \mathrm{Tc}$ & $2.13 \times 10^{5}$ & beta & FP, ${ }^{99} \mathrm{Ru}$ \\
\hline Palladium & ${ }^{107} \mathrm{Pd}$ & $6.5 \times 10^{6}$ & beta & $\mathrm{FP},{ }^{106} \mathrm{Pd}$ \\
\hline Cadmium & ${ }^{113 m} \mathrm{Cd}$ & 14.1 & beta & FP \\
\hline \multirow[b]{2}{*}{ Tin } & ${ }^{121 \mathrm{~m}} \mathrm{Sn}$ & $\sim 55$ & beta & $\mathrm{FP},{ }^{120} \mathrm{Sn}$ \\
\hline & ${ }^{126} \mathrm{Sn}$ & $2.5 \times 10^{5}$ & beta & FP \\
\hline lodine & ${ }^{129} I$ & $1.57 \times 10^{7}$ & beta & $\mathrm{FP},{ }^{129} \mathrm{Xe}$ \\
\hline \multirow[b]{2}{*}{ Cesium } & ${ }^{135} \mathrm{Cs}$ & $2.3 \times 10^{6}$ & beta & FP \\
\hline & ${ }^{137} \mathrm{Cs}$ & 30.07 & beta & $\mathrm{FP},{ }^{137} \mathrm{Ba}$ \\
\hline Samarium & ${ }^{151} \mathrm{Sm}$ & 90 & beta & $\mathrm{FP},{ }^{150} \mathrm{Sm}$ \\
\hline \multirow{3}{*}{ Europium } & ${ }^{150} \mathrm{Eu}$ & 36 & beta & ${ }^{151} \mathrm{Eu}$ \\
\hline & ${ }^{152} \mathrm{Eu}$ & 13.54 & beta & ${ }^{151} \mathrm{Eu},{ }^{153} \mathrm{Eu}$ \\
\hline & ${ }^{154} \mathrm{Eu}$ & 8.593 & beta & ${ }^{153} \mathrm{Eu}$ \\
\hline Holmium & ${ }^{166} \mathrm{Ho}$ & $1.2 \times 10^{3}$ & beta & $\mathrm{FP},{ }^{165} \mathrm{Ho}$ \\
\hline Thorium & ${ }^{232} \mathrm{Th}$ & $1.40 \times 10^{10}$ & & natural and device component \\
\hline \multirow{6}{*}{ Uranium } & ${ }^{232} U$ & 69.8 & alpha & device component, ${ }^{233} \mathrm{U}$ \\
\hline & ${ }^{233} \mathrm{U}$ & $1.592 \times 10^{5}$ & alpha & device component, radiochemical tracer \\
\hline & ${ }^{234} \mathrm{U}$ & $2.46 \times 10^{5}$ & alpha & natural and device component \\
\hline & ${ }^{235} \mathrm{U}$ & $7.04 \times 10^{8}$ & alpha & natural and device component \\
\hline & ${ }^{236} U$ & $2.342 \times 10^{7}$ & alpha & device component, ${ }^{235} \mathrm{U},{ }^{238} \mathrm{U}$ \\
\hline & ${ }^{238} \mathrm{U}$ & $4.47 \times 10^{9}$ & alpha & natural and device component \\
\hline Neptunium & ${ }^{237} \mathrm{~Np}$ & $2.14 \times 10^{6}$ & alpha & radiochemical tracer, decay of ${ }^{237} \mathrm{U}$ \\
\hline \multirow{5}{*}{ Plutonium } & ${ }^{238} \mathrm{Pu}$ & 87.7 & alpha & device component, radiochemical tracer, ${ }^{239} \mathrm{Pu},{ }^{237} \mathrm{~Np}$ \\
\hline & ${ }^{239} \mathrm{Pu}$ & $2.410 \times 10^{4}$ & alpha & device component, decay of ${ }^{239} \mathrm{U}$ \\
\hline & ${ }^{240} \mathrm{Pu}$ & $6.56 \times 10^{3}$ & alpha & device component, ${ }^{239} \mathrm{Pu}$, decay of ${ }^{240} \mathrm{U}$ \\
\hline & ${ }^{241} \mathrm{Pu}$ & 14.4 & beta & device component, ${ }^{240} \mathrm{Pu}$, decay of ${ }^{241} \mathrm{U}$ \\
\hline & ${ }^{242} \mathrm{Pu}$ & $3.75 \times 10^{5}$ & alpha & $\begin{array}{l}\text { device component, radiochemical tracer, }{ }^{241} \mathrm{Pu} \text {, } \\
\text { decay of }{ }^{242} \mathrm{U}\end{array}$ \\
\hline \multirow{2}{*}{ Americium } & ${ }^{241} \mathrm{Am}$ & 432.7 & alpha & device component, radiochemical tracer, decay of ${ }^{241} \mathrm{Pu}$ \\
\hline & ${ }^{243} \mathrm{Am}$ & $7.37 \times 10^{3}$ & alpha & device component, radiochemical tracer \\
\hline Curium & ${ }^{244} \mathrm{Cm}$ & 18.1 & alpha & radiochemical tracer \\
\hline
\end{tabular}




\subsection{Evaluation of the Monitoring Network}

The monitoring network at the Salmon site consists of 28 wells and 11 surface water locations (Table 7). The wells were installed to monitor for potential contaminant migration from the detonation cavity and surface release areas near SGZ and at several disposal pits. Well locations and screen depths are being evaluated with respect to assumed source locations and interpreted flow directions within aquifers to determine if potential transport pathways are being effectively monitored.

\subsection{Surface Water Locations}

Four surface water locations monitor the creeks as they enter the site (Half Moon Cr. Entry, Hickory Hollow Cr. Entry, Grantham Cr. Entry), one is in Hickory Hollow Creek off the site (HickHCrTSD-East). Three surface locations are in SA1 (Half Moon Creek, Half Moon Creek Overflow, and the Pond West of SGZ), and the three surface locations in SA2 are REECo Pit (A), REECo Pit (B), and REECo Pit (C) (Table 7).

\subsection{Well Locations and Completions}

Wells onsite are completed in all of the aquifers except Aquifer 3b, Aquifer 5, and the citronelle aquifer. Twelve wells are in the Alluvial Aquifer: seven are in the Local Aquifer; one each is in Aquifers 1, 2a, 2b, and the Caprock Aquifer; three are in Aquifer 3; and two are in Aquifer 4. Eleven of the Alluvial Aquifer wells are located in area SA1, and one is in SA3. Two Local Aquifer wells are in area SA1, three are in SA2, and two are in SA4. The wells in Aquifers 1, 2a, and $2 b$ are all in area SA1 near SGZ. One Aquifer 3 well is in SA3, and two Aquifer 3 wells are in SA1. Both of the Aquifer 4 wells are in SA5 (Table 7). 
Table 7. Monitoring Network Locations

\begin{tabular}{|c|c|c|c|c|}
\hline $\begin{array}{l}\text { Year Location } \\
\text { Established }\end{array}$ & $\begin{array}{l}\text { Location } \\
\text { Type }\end{array}$ & Location & Aquifer & Area \\
\hline 2002 & Well & $\mathrm{HMH}-16 \mathrm{R}$ & Alluvial & SA1 \\
\hline 2002 & Well & HMH-5R & Alluvial & SA1 \\
\hline 1979 & Well & HM-S & Alluvial & SA1 \\
\hline 2002 & Well & SA1-12-H & Alluvial & SA1 \\
\hline 1995 & Well & SA1-1-H & Alluvial & SA1 \\
\hline 1995 & Well & SA1-2-H & Alluvial & SA1 \\
\hline 1995 & Well & SA1-3-H & Alluvial & SA1 \\
\hline 1995 & Well & SA1-4-H & Alluvial & SA1 \\
\hline 1995 & Well & SA1-5-H & Alluvial & SA1 \\
\hline 1995 & Well & SA1-6-H & Alluvial & SA1 \\
\hline 1995 & Well & SA1-7-H & Alluvial & SA1 \\
\hline 1995 & Well & SA3-4-H & Alluvial & SA3 \\
\hline 1979 & Well & HM-L & Local & SA1 \\
\hline 1997 & Well & SA1-8-L & Local & SA1 \\
\hline 1996 & Well & SA2-1-L & Local & SA2 \\
\hline 1996 & Well & SA2-2-L & Local & SA2 \\
\hline 1996 & Well & SA2-4-L & Local & SA2 \\
\hline Unknown & Well & HM-L2 & Local & SA4 \\
\hline 2002 & Well & SA4-5-L & Local & SA4 \\
\hline 1979 & Well & $\mathrm{HM}-1$ & Aquifer 1 & SA1 \\
\hline 1979 & Well & $\mathrm{HM}-2 \mathrm{~A}$ & Aquifer 2a & SA1 \\
\hline 1979 & Well & $\mathrm{HM}-2 \mathrm{~B}$ & Aquifer $2 b$ & SA1 \\
\hline 1996 & Well & SA3-11-3 & Aquifer 3 & SA3 \\
\hline 1979 & Well & $\mathrm{HM}-3$ & Aquifer 3 & SA1 \\
\hline 1996 & Well & SA1-11-3 & Aquifer 3 & SA1 \\
\hline 1996 & Well & SA5-4-4 & Aquifer 4 & SA5 \\
\hline 1996 & Well & SA5-5-4 & Aquifer 4 & SA5 \\
\hline 1972 & Well & $\mathrm{E}-7$ & Caprock & SA3 \\
\hline 2008 & Surface & HickHCrTSD-East & Surface Water & Offsite \\
\hline 1972 & Surface & Half Moon Cr. Overflow & Surface Water & SA1 \\
\hline 1972 & Surface & Half Moon Creek & Surface Water & SA1 \\
\hline 1972 & Surface & Pond West of SGZ & Surface Water & SA1 \\
\hline 1980 & Surface & REECo Pit (A) & Surface Water & SA2 \\
\hline 1980 & Surface & REECo Pit (B) & Surface Water & SA2 \\
\hline 1980 & Surface & REECo Pit (C) & Surface Water & SA2 \\
\hline 2008 & Surface & Grantham Cr. Entry & Surface Water & Site Boundary \\
\hline 2008 & Surface & Half Moon Cr. Entry & Surface Water & Site Boundary \\
\hline 2008 & Surface & Half Moon Cr. Exit & Surface Water & Site Boundary \\
\hline 2008 & Surface & Hickory Hollow Cr. Entry & Surface Water & Site Boundary \\
\hline
\end{tabular}




\subsubsection{SGZ Well Cluster}

The wells near SGZ are positioned to detect contaminants migrating from the shot cavity. The six wells (HM-S, HM-L, HM-1, HM-2A, HM-2B, and HM-3) monitor each of the aquifers over the dome: the Alluvial Aquifer, the Local Aquifer, Aquifer 1, Aquifer 2a, Aquifer 2b, and Aquifer 3 (Figure 22). Water levels indicate a downward gradient from the Alluvial Aquifer to Aquifer 2b (Figure 23). At depth, the vertical gradient is reversed with a slight upward gradient from Aquifer 3 to Aquifer 2b (Figure 22 and Figure 23). The downward gradient indicates that contamination from the cavity is unlikely to migrate above Aquifer $2 \mathrm{~b}$. The most likely migration path for near-surface contamination within the Alluvial Aquifer would be east toward Half Moon Creek. However, the downward gradient between the Alluvial Aquifer and the Local Aquifer in this area makes it possible for near-surface contamination around SGZ to potentially migrate downward to the Local Aquifer.

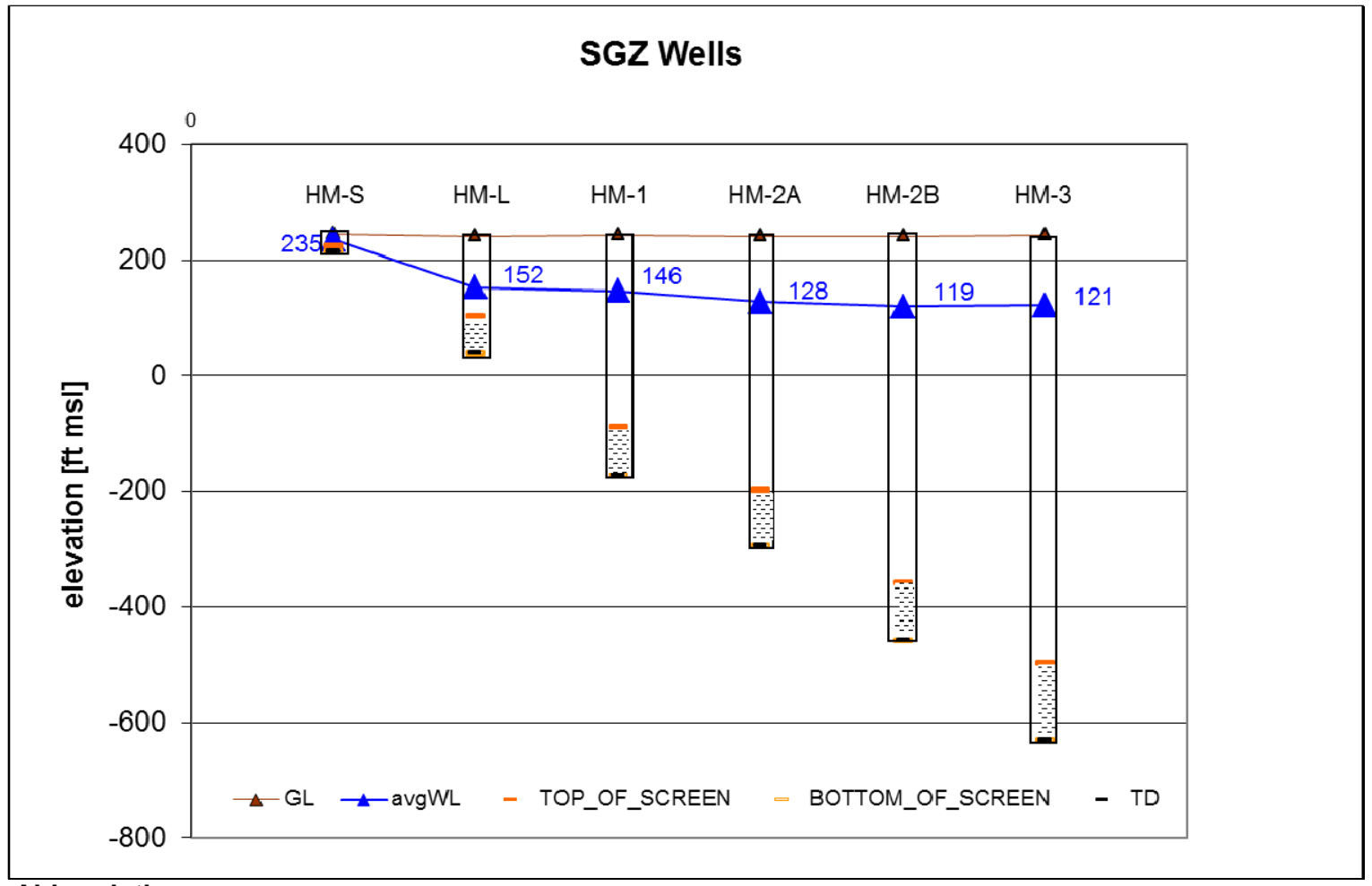

Abbreviations

avgWL = Average Water Level

$\mathrm{GL}=$ Ground Level

$\mathrm{msl}=$ mean sea level

TD $=$ Total Depth

Figure 22. Screened Intervals and Water Levels of SGZ Wells 


\subsubsection{Alluvial Aquifer Wells}

Twelve wells monitor the Alluvial Aquifer (Figure 23), and all are located in the Half Moon Creek floodplain. The water levels in the wells are all within a few feet of each other and the stream elevation. The lowest water levels are in wells HMH-5R (lowest elevation) and SA1-12-H (farthest downstream). The highest Alluvial Aquifer water level is in the farthest upstream well, SA3-4-H. The predominant horizontal groundwater flow direction in the Alluvial Aquifer is locally toward Half Moon Creek. The significantly higher heads in the Alluvial Aquifer relative to those in the underlying Local Aquifer suggest a vertical downward component of flow.

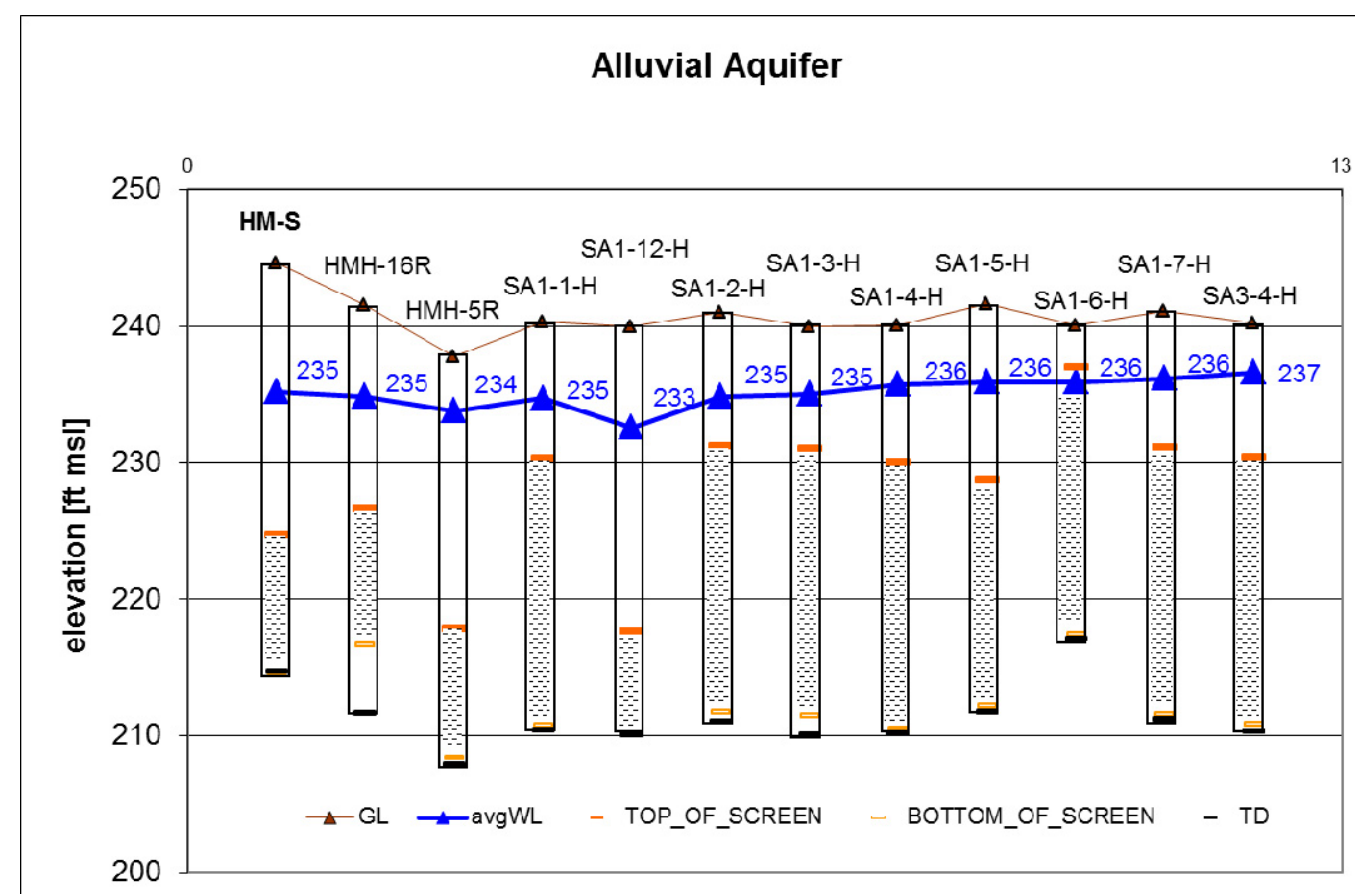

\section{Abbreviations}

avgWL = Average Water Level

$\mathrm{GL}=$ Ground Level

$\mathrm{msl}=$ mean sea level

TD $=$ Total Depth

Figure 23. Screened Intervals and Water Levels in the Alluvial Aquifer 


\subsubsection{Local Aquifer Wells}

Seven wells are completed in the Local Aquifer; three are west of Half Moon Creek (HM-L, HM-L2, and SA4-5-L), three are on the east side near the REECo Disposal Pits (SA2-1-L, SA2-2-L, SA2-4-L), and one is southeast of the junction of Grantham and Half Moon Creeks (SA1-8-L). The lowest water level is in well HM-L near SGZ. The other wells (all located on highlands east and west of Half Moon Creek) have higher water level elevations than HM-L, suggesting that flow in the Local Aquifer is locally toward the Half Moon Creek topographic basin from the east, west, and south of the site. Gardner and Downs (1971) describe the central site within a half-mile radius of SGZ as a topographical basin, but geologically as a structural dome. Additional Local Aquifer wells north of SGZ would further delineate the horizontal flow within the Local Aquifer. Water levels in the Local Aquifer at SGZ (well HM-L) are $152 \mathrm{ft}$ above mean sea level (msl), water levels in wells to the east (about 0.5 mile) are around $157 \mathrm{ft} \mathrm{msl}$, and water levels to the west (about $0.4 \mathrm{mile}$ ) are around $155 \mathrm{ft} \mathrm{msl}$ (Figure 24). This suggests that the horizontal gradient in the Local Aquifer is about 5 to $10 \mathrm{ft}$ per mile toward the basin center.

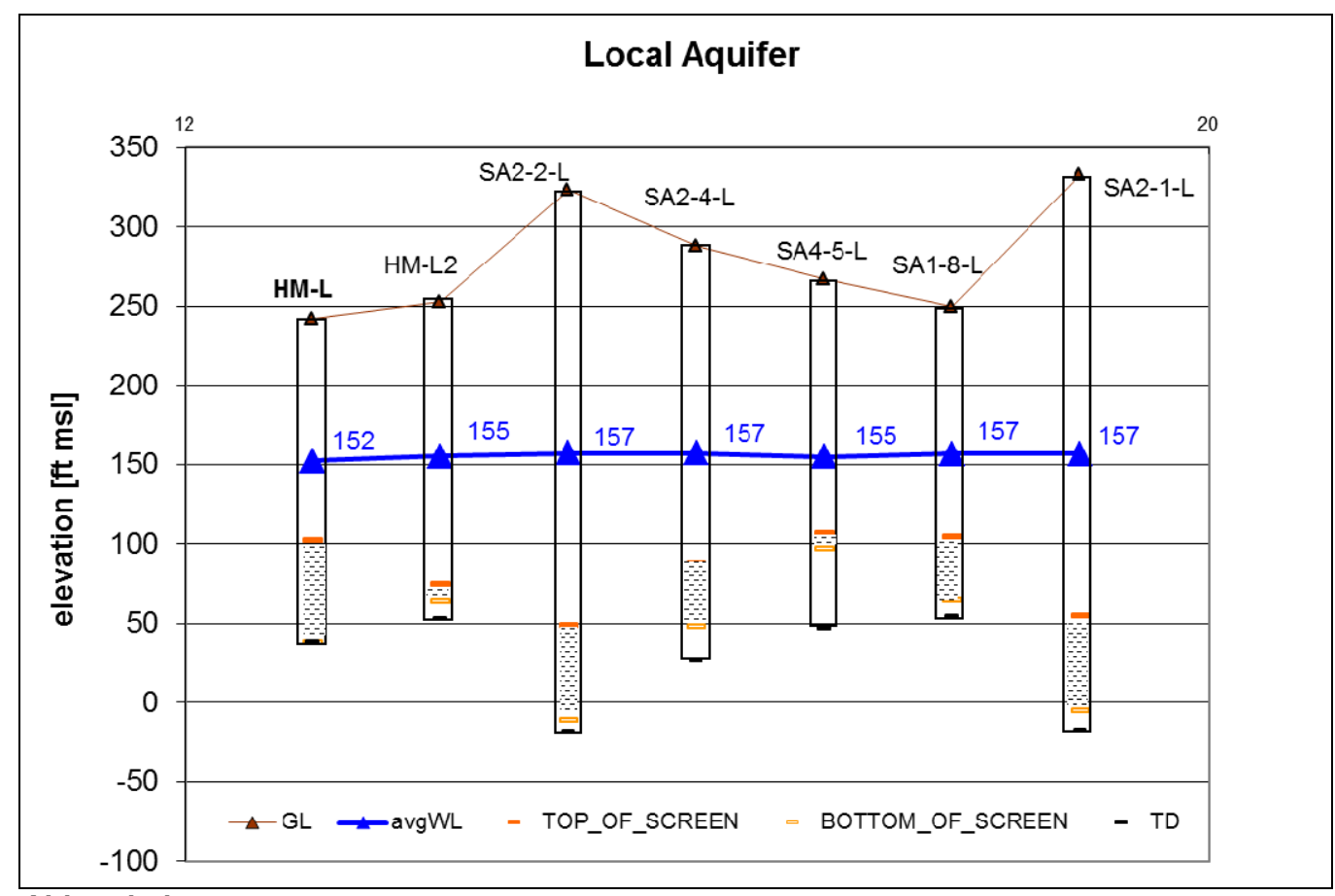

\footnotetext{
Abbreviations

avgWL = Average Water Level

$\mathrm{GL}=$ Ground Level

$\mathrm{msl}=$ mean sea level

TD = Total Depth
}

Figure 24. Screened Intervals and Water Levels in the Local Aquifer 


\subsubsection{Aquifer 2 Wells}

Aquifer 2 is composed of two separate hydrologic units at the Salmon site (Aquifer 2a and Aquifer 2b). These units are monitored by wells HM-2A and HM-2B (Figure 25) near SGZ. The $9 \mathrm{ft}$ head difference between Aquifer 2a (128 ft msl) and Aquifer $2 \mathrm{~b}(119 \mathrm{ft} \mathrm{msl})$ creates a downward vertical gradient between the intervals. This is a continuation of the downward vertical gradient from the Alluvial Aquifer to Aquifer 2b. The vertical gradient is reversed between Aquifer 2b and Aquifer 3 (Figure 25), creating a slightly upward gradient between these units. The water level in HM-2B is closer to that of HM-3 than HM-2A, suggesting that Aquifer $2 \mathrm{~b}$ may be more connected to Aquifer 3 than Aquifer 2a. No other wells are completed in either Aquifer $2 \mathrm{a}$ or Aquifer $2 \mathrm{~b}$ at the site, and no horizontal gradient can be determined.

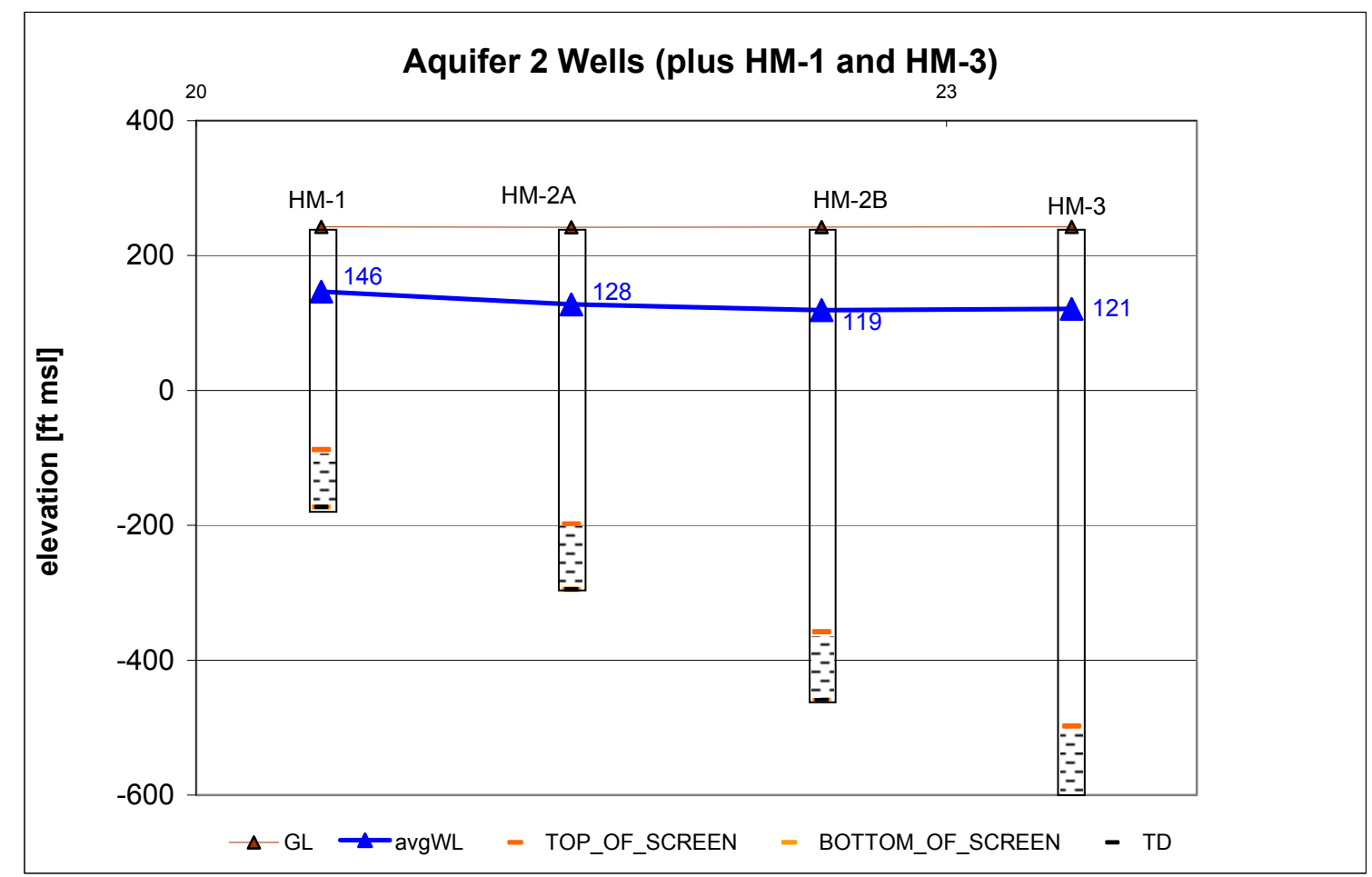

\section{Abbreviations}

avgWL = Average Water Level

$\mathrm{GL}=$ Ground Level

$\mathrm{msl}=$ mean sea level

TD $=$ Total Depth

Figure 25. Screened Intervals and Water Levels of Aquifer 2 Wells 


\subsubsection{Aquifer 3 Wells}

Three wells are completed in Aquifer 3 (SA3-11-3, HM-3, and SA1-11-3); all are located above the salt dome. Wells SA3-11-3 and HM-3 are listed in the current DOE database as being completed in Aquifer $3 \mathrm{~b}$ though all of the historical geologic and hydrologic descriptions referenced in this report indicate that Aquifer $3 b$ does not exist above the dome. The screened zone and water elevation data from these three wells suggest they are in the same hydrologic unit (Figure 26). It is recommended that these wells be considered as completed in the same aquifer and that the database be corrected to reflect this. Wells in Aquifer 3 and the overlying Aquifer $2 b$ have the lowest head levels at the site, causing vertical gradients from units above and below to be toward this interval, making them good monitoring candidates.

One of the Aquifer 3 wells (HM-3) is located at the SGZ well cluster. Well SA3-11-3 is on the west side of Half Moon Creek about a third of a mile south of SGZ, and well SA1-11-3 is east of Half Moon Creek, about a third of a mile southeast of SGZ. The water levels in these wells indicate that horizontal flow in Aquifer 3 is to the southeast, though confidence in flow directions based on only three wells with small head differences is limited.

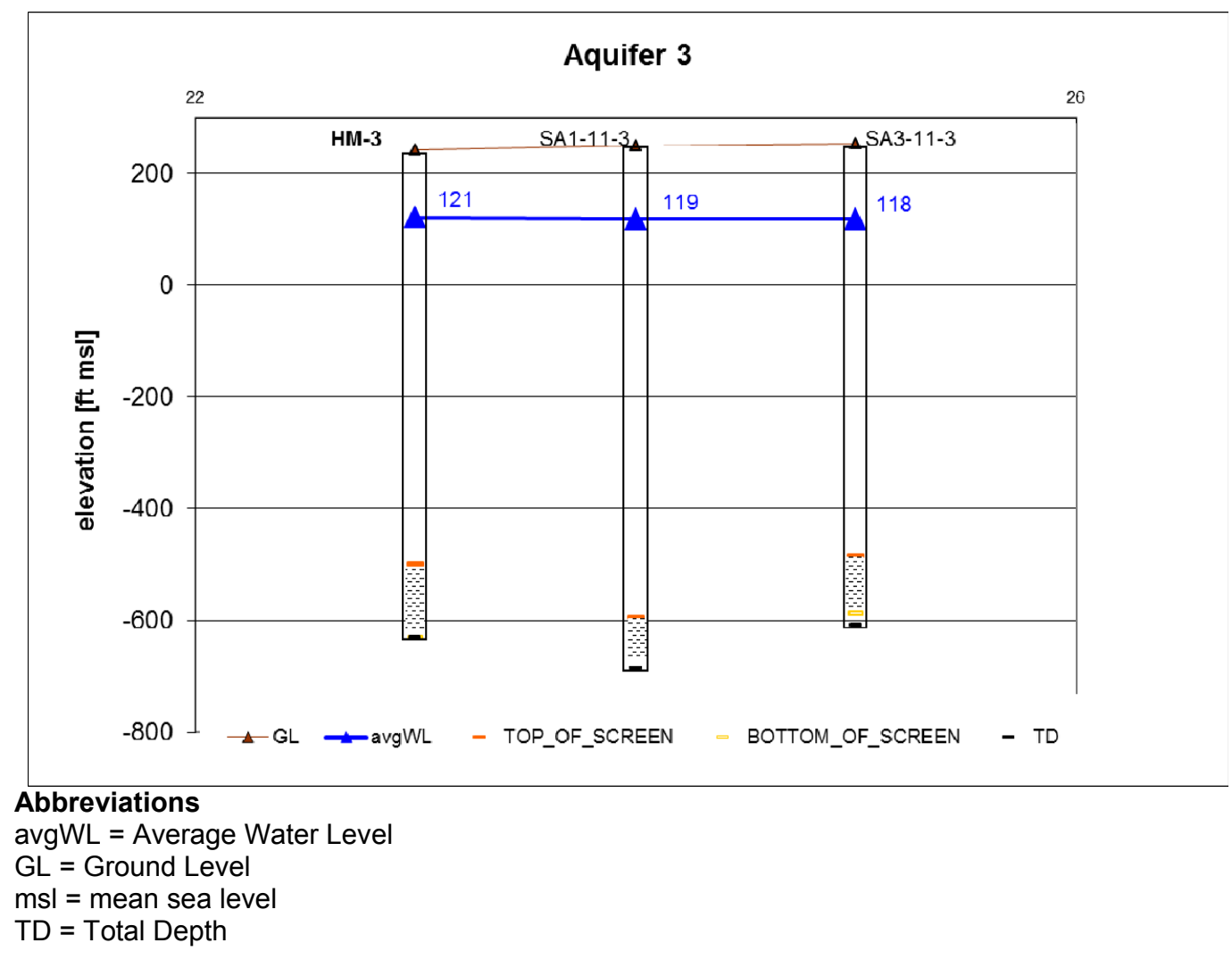

Figure 26. Screened Intervals and Water Levels in Aquifer 3 


\subsubsection{Aquifer 4 Wells}

Two wells are completed in Aquifer 4 to monitor the hydrologic unit above the former injection well HT-2 (Figure 18). Water levels in Aquifer 4 are more than $20 \mathrm{ft}$ higher than those in Aquifer 3, indicating an upward vertical gradient. In this area of the site, which is off of the dome, Aquifer 3 is separated into $3 \mathrm{a}$ and $3 \mathrm{~b}$ components by confining layers in the Catahoula Sandstone. No wells are completed in Aquifer 3b; however, it is presumed that the water levels in $3 b$ would be higher than those in Aquifer 3 over the dome (3a). It also is presumed that head levels in the underlying Aquifer 5, where the injection of contamination occurred, remain higher than those in Aquifer 4. Aquifer 5 is not directly monitored. Water levels in well SA5-5-4 (144 ft msl) are $8 \mathrm{ft}$ higher than those in well SA5-4-4 (Figure 27), suggesting that horizontal flow in Aquifer 4 might be to the northeast, although flow directions interpreted from only two wells is highly uncertain.

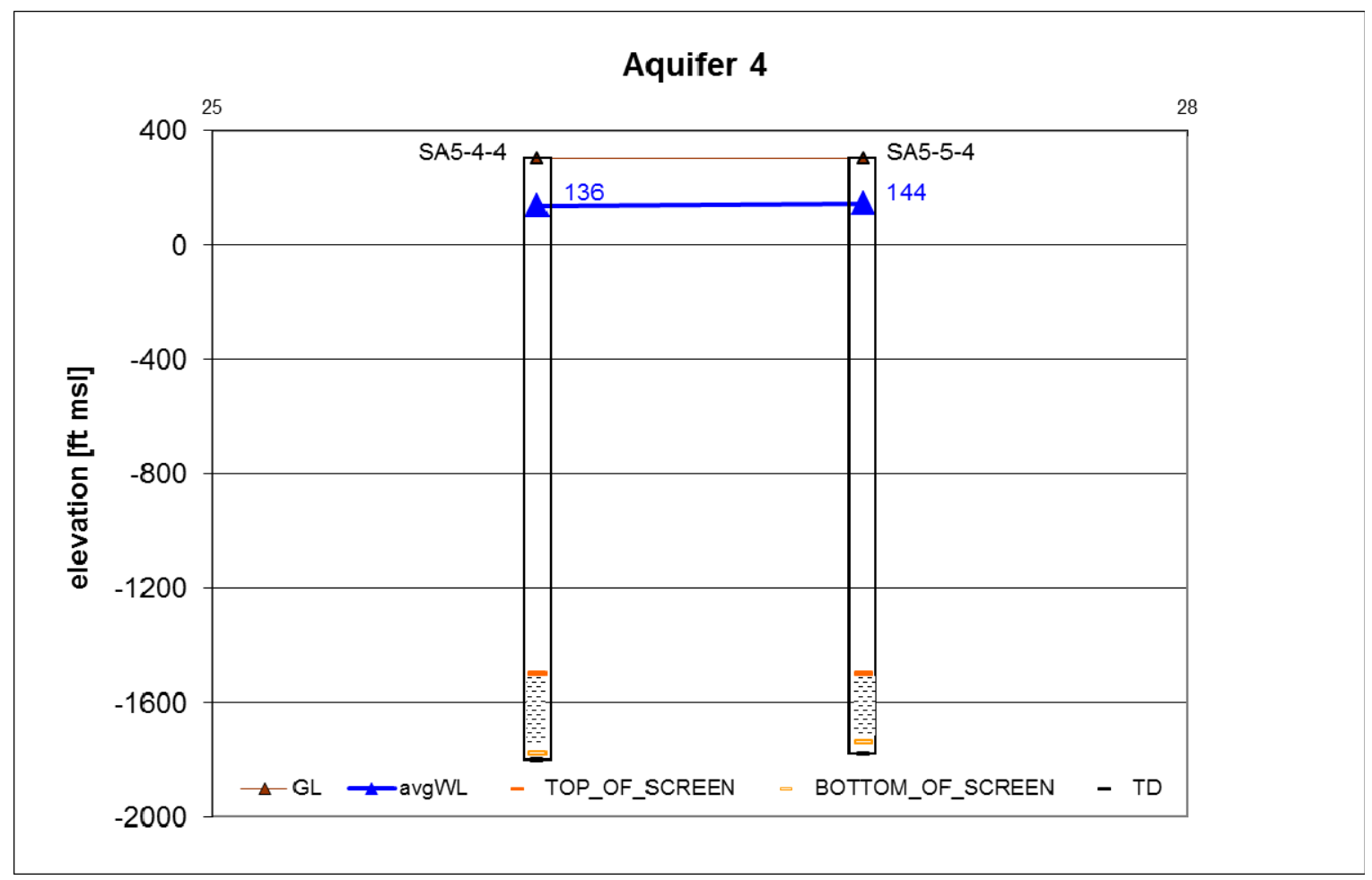

Figure 27. Screened Intervals and Water Levels in Aquifer 4

\subsection{Conceptual Model of Flow}

Water levels in site wells can be used to infer vertical gradients between aquifers in locations with multiple wells completed (1) in different hydrologic units (such as the SGZ well cluster) and (2) in horizontal gradients within individual aquifers that have multiple wells spatially distributed (Alluvial Aquifer, Local Aquifer, and Aquifer 3). There is an overall downward gradient at SGZ from the Alluvial Aquifer down to Aquifer 2b (Figure 28). The gradient is steepest across the confining unit that separates the Alluvial Aquifer from the Local Aquifer (over $80 \mathrm{ft}$ of head difference, Figure 22) and decreases across each successive confining unit until Aquifer 2b, which is the lowest water level at the SGZ well cluster. 


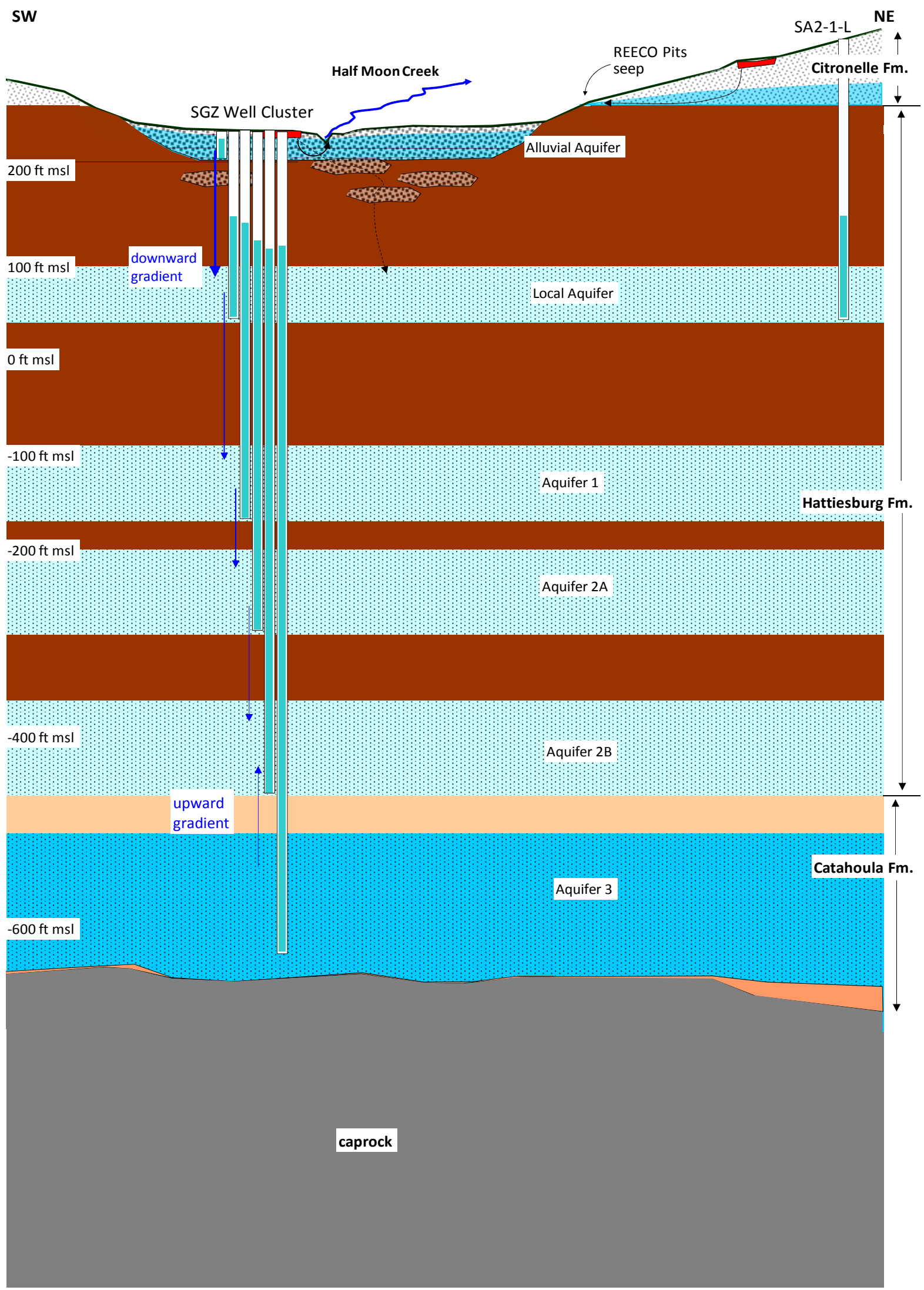

Figure 28. Conceptual Model of Flow Relative to Half Moon Creek and SGZ 
Water levels suggest that the downward gradient reverses to a slight upward gradient from Aquifer 3 to Aquifer $2 b$, though the difference $(2 \mathrm{ft})$ is small enough that there may be no significant separation between these aquifers. This is consistent with the lithostratigraphy in that Aquifer $2 \mathrm{~b}$ and Aquifer 3 are both within the Catahoula Formation, and the overlying Aquifer $2 \mathrm{a}$ is in the Hattiesburg Formation (Figure 21). On the surrounding highlands where the surficial aquifer is the Citronelle Formation (the Alluvial Aquifer is only present in the stream valleys), an even stronger downward gradient would be present, supported by a thicker section of the Hattiesburg Formation (Figure 28). There is probably minimal downward leakage across this thick aquitard, with the majority of water flowing laterally within the Citronelle to hillside seeps (Figure 28).

The majority of flow within the Alluvial Aquifer is toward the streams that deposited the material within the stream valleys (northeast to Half Moon Creek at SGZ). Near Half Moon Creek the flow may be somewhat diverted to the northwest in the direction of stream flow. Water levels in Local Aquifer wells southwest and northeast of the site also indicate that horizontal flow is toward Half Moon Creek. The water level at well SA1-8-L southeast of SGZ indicates the presence of a southeast to northwest component of flow. This indicates that flow directions in the Local Aquifer are similar to those in the Alluvial Aquifer, which suggests that these aquifers may be more closely related than the large head differences between them would indicate. Sufficient well data are not available to determine the thickness variability of the alluvium within the Half Moon Creek Valley and therefore the thickness of the confining unit separating the Alluvial and Local Aquifers. The three wells completed in Aquifer 3 allow a southeast horizontal flow direction to be inferred, though the similarity of water levels in these wells and the Aquifer $2 \mathrm{~b}$ well (maximum of $3 \mathrm{ft}$ ) indicates that the flow direction could vary.

The surface contamination shown on the conceptual flow diagram (red boxes on Figure 28) show how contamination near SGZ and near the REECo Disposal Pits is expected to migrate within the flow system. The majority of surface contamination near SGZ should migrate within the Alluvial Aquifer to Half Moon Creek. The potential for downward migration to the underlying Local Aquifer is also possible. Contamination near the REECo Disposal Pits will most likely migrate laterally to hillside seeps. Saturation of the Citronelle will vary during the year in response to precipitation, causing seep flow rates and concentrations to also vary.

\subsection{Water Level Fluctuations}

The Local Aquifer wells are equipped with water level transducers and data loggers to record water levels every $4 \mathrm{hr}$ (hours) to supplement the quarterly to yearly manual readings. Water levels taken during the annual sampling in April are relatively steady from year to year. Annual water levels do not capture the variability due to seasonal changes or large precipitation events. Precipitation data from the city of Purvis (10 miles east of the site, NOAA station ID: COOP:227220) show seasonal variations in precipitation, with the majority of precipitation occurring from late fall through spring. The hydrographs of Local Aquifer wells (Figure 29) follow the same yearly pattern with water levels varying by more than $3 \mathrm{ft}$ between spring and fall. Water level variations are expected to be different for each aquifer, with greater variability associated with shallower aquifers that are more directly affected by precipitation. Data from transducers recently installed in Aquifer 4 wells show variations of $1 \mathrm{ft}$ or less, although there appears to be a seasonal component even with the limited data set (Figure 30). 
Seasonal water level variations affect both the direction and magnitude of groundwater gradients, which in turn influence the migration of potential contaminant plumes, possibly causing concentrations at monitoring wells to vary throughout the year. For instance, samples taken at a well during increased flow periods could be somewhat diluted, providing a lower sample concentration result. Conversely, contaminants might be mobilized during increased flow periods providing higher results. Figures 31 through 35 show the well hydrographs individually plotted with the precipitation data. It is recommended that an 18-month interval be adopted that alternates between spring and fall sampling events to capture possible variations in concentrations due to seasonal fluctuations in flow.

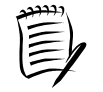

In the water-level charts in Figures 29-35,the individual data points shown as triangles, squares, and diamonds are data from manual sampling, and the colored Note $\quad$ lines are data collected automatically by transducers.

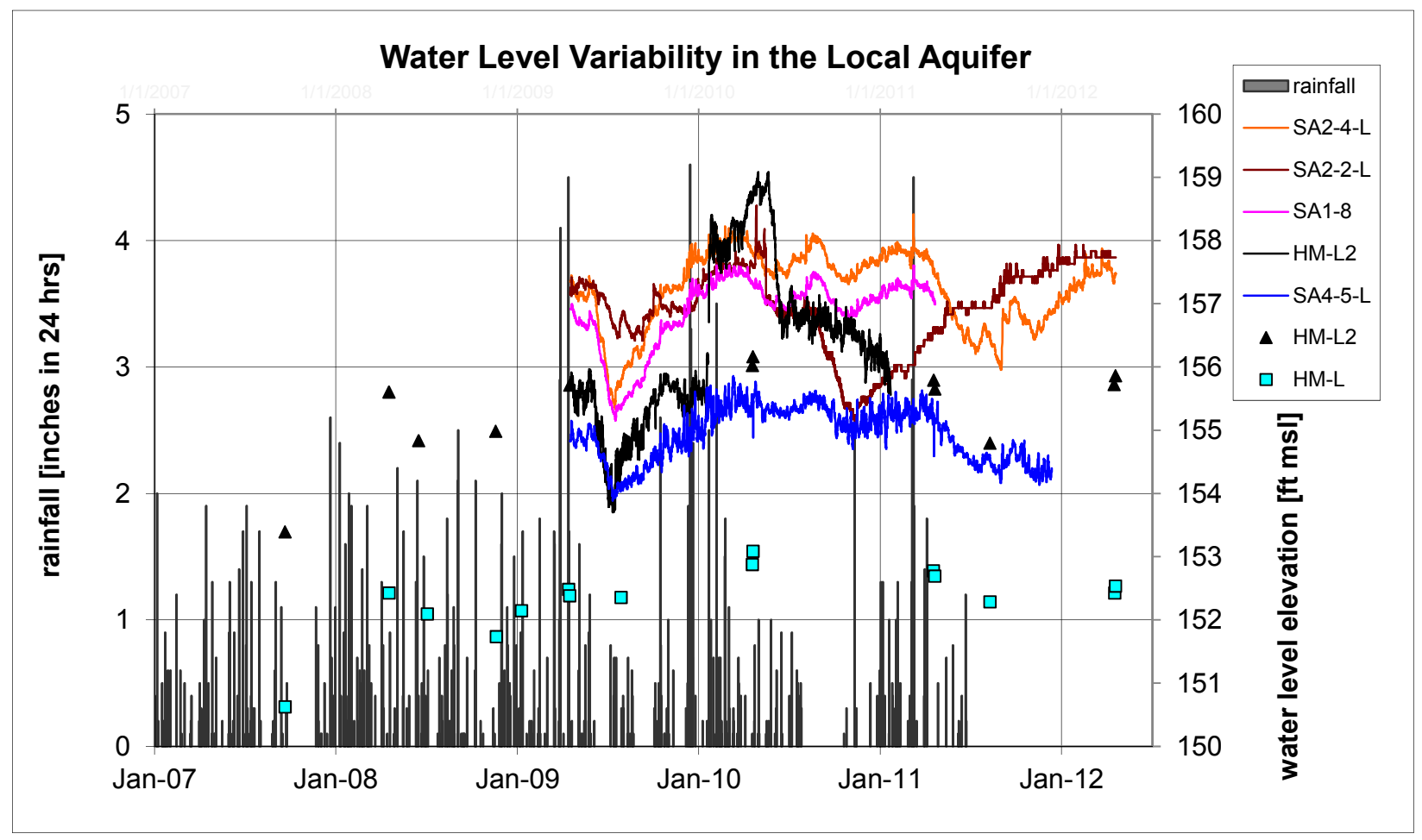

Figure 29. Local Aquifer Water Levels 


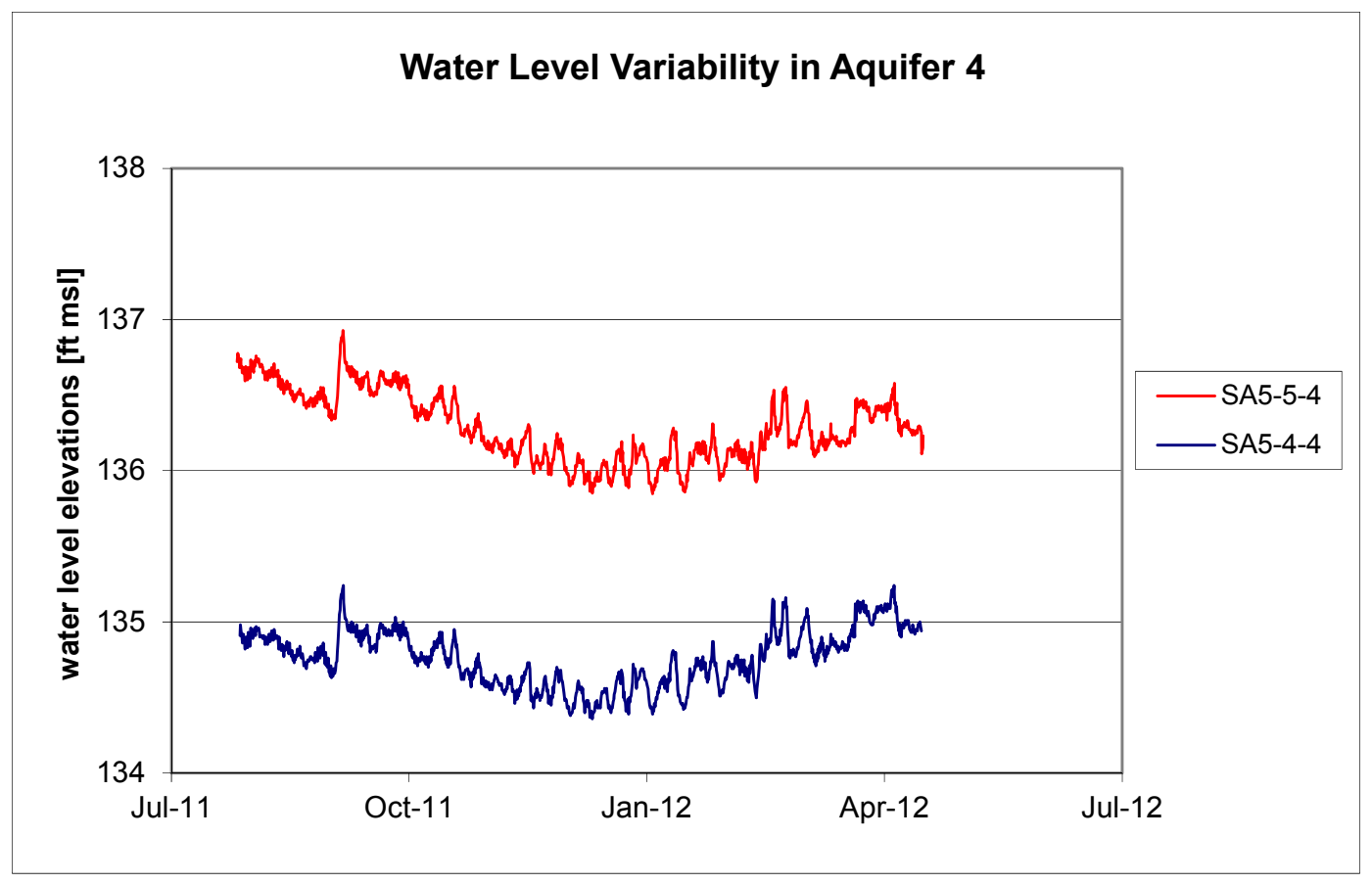

Figure 30. Water Levels from Aquifer 4 Wells

The average water level at HM-L2 from the annual sampling events is $155 \mathrm{ft}$ msl (Figure 31). The lowest water level was in September 2007 at $153 \mathrm{ft}$ msl, and the highest was in July of 2010 at $159 \mathrm{ft} \mathrm{msl}$.

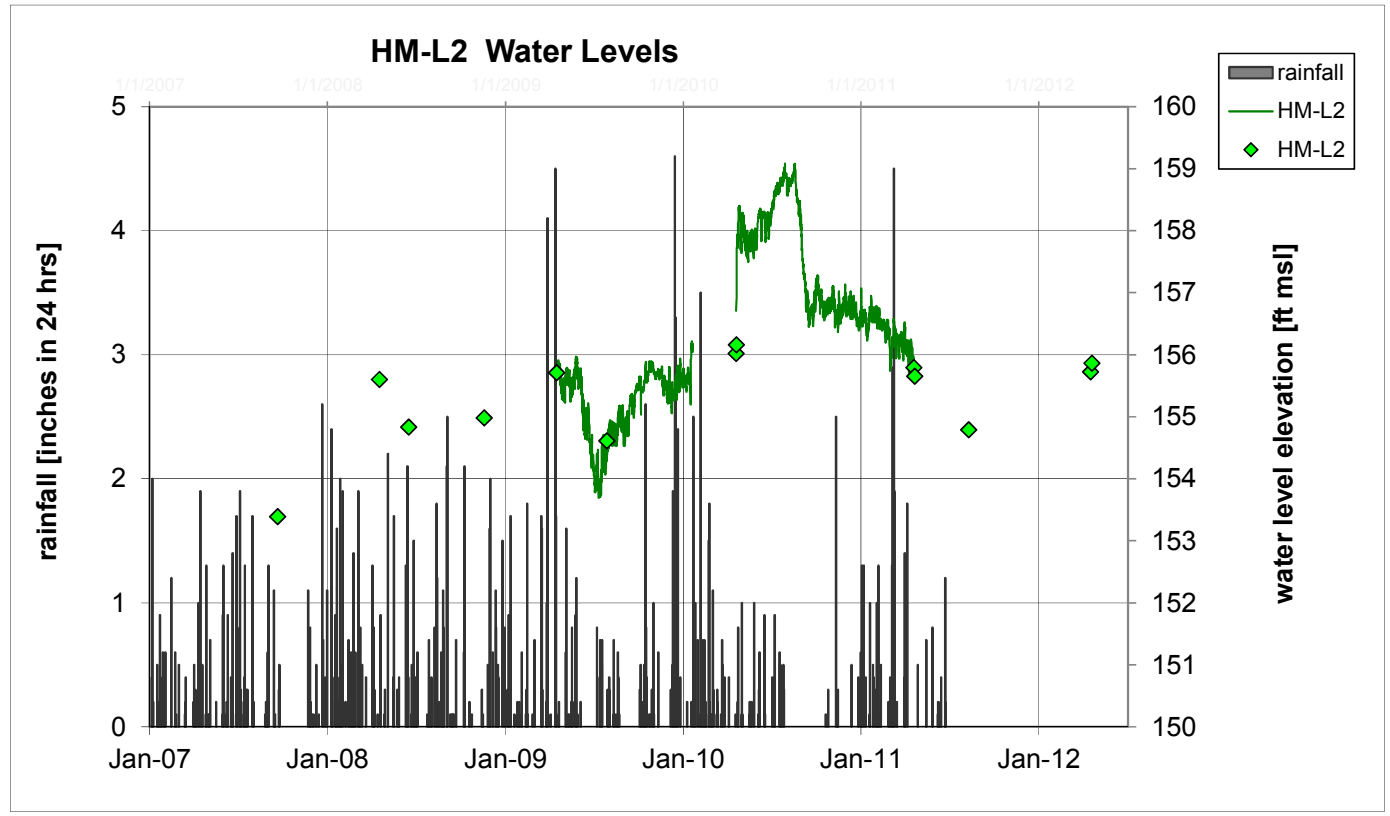

Figure 31. HM-L2 Water Levels 
The average water level at SA2-4-L from the annual sampling events is $157 \mathrm{ft} \mathrm{msl}$ (Figure 32). The lowest water level was in July 2009 at $155 \mathrm{ft}$ msl, and the highest was in March of 2011 at $158 \mathrm{ft} \mathrm{msl}$.

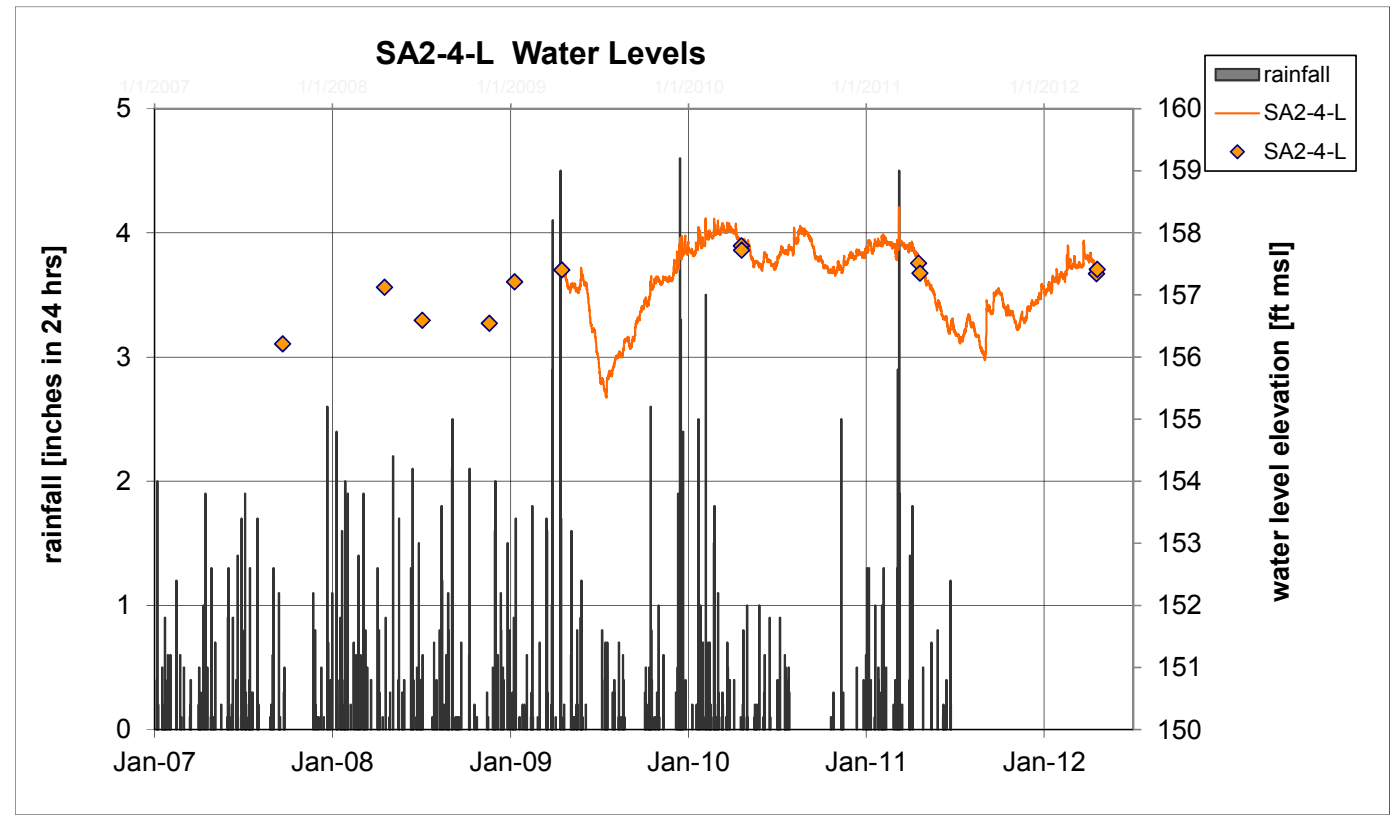

Figure 32. SA2-4-L Water Levels

The average water level at SA2-2-L from the annual sampling events is $157 \mathrm{ft}$ msl (Figure 33). The lowest water level was in July 2009 at $155 \mathrm{ft}$ msl, and the highest was in March 2009 at $158 \mathrm{ft} \mathrm{msl}$.

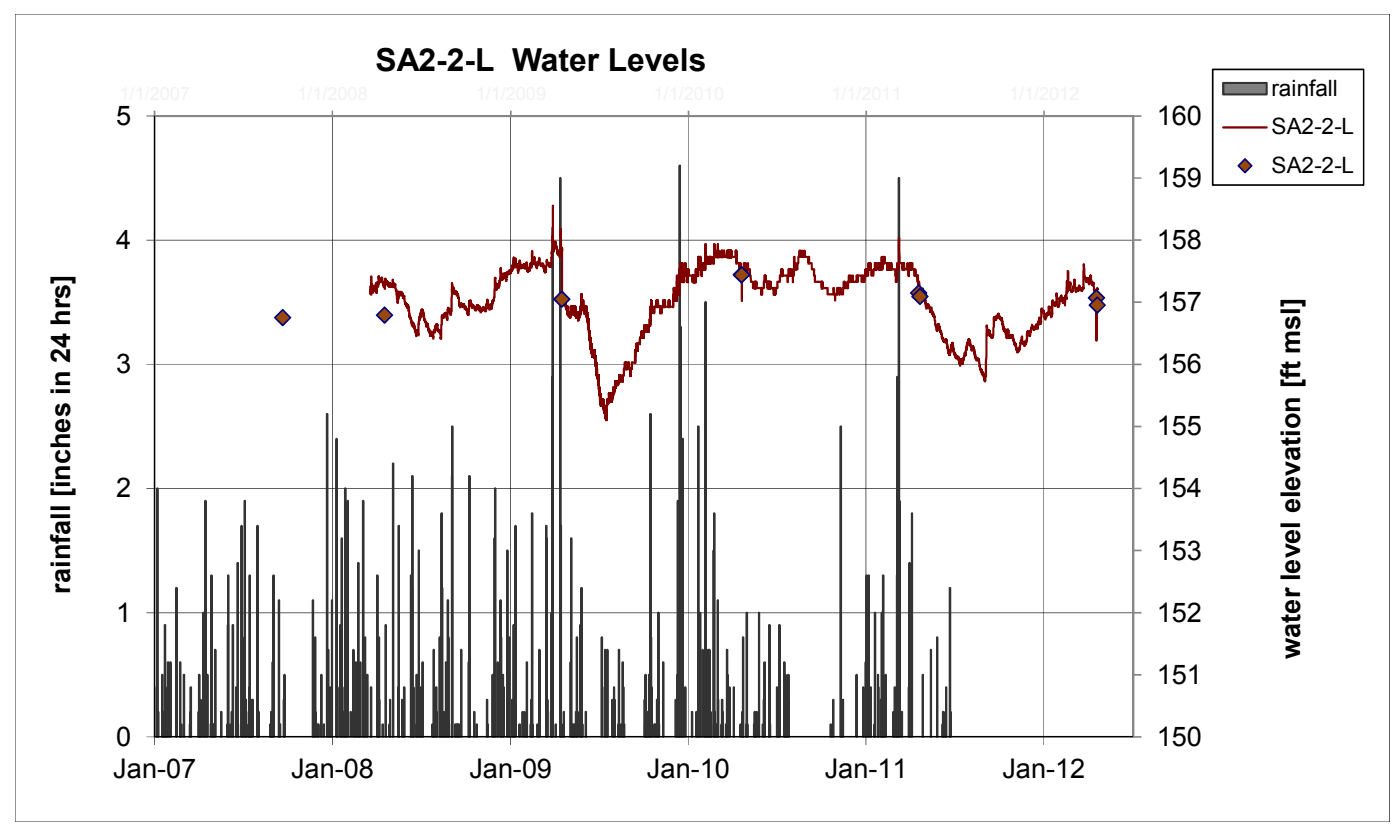

Figure 33. SA2-2-L Water Levels 
The average water level at SA1-8-L from the annual sampling events is $157 \mathrm{ft}$ msl (Figure 34). The lowest water level was in July 2009 at $155 \mathrm{ft}$ msl, and the highest was in March 2011 at $157 \mathrm{ft} \mathrm{msl}$.

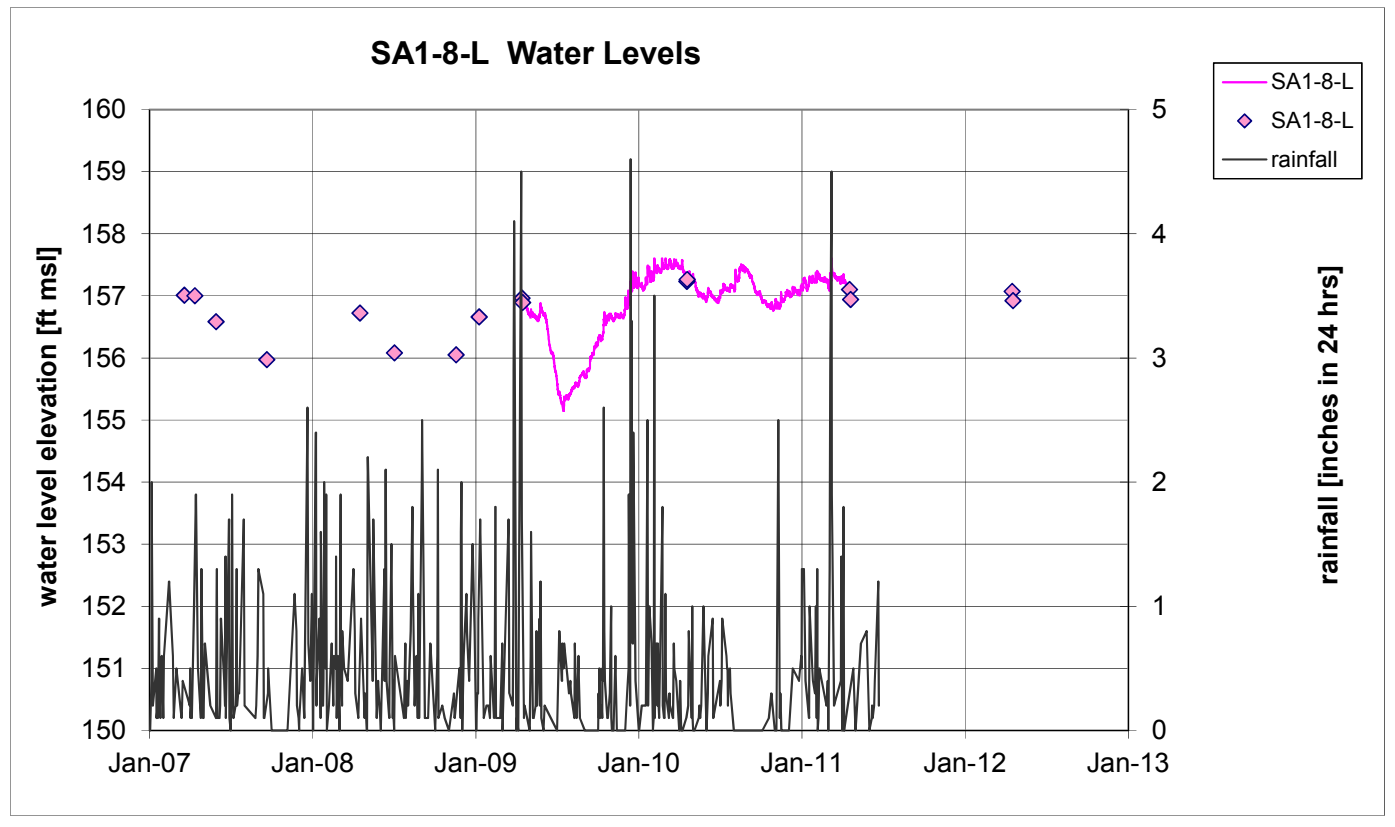

Figure 34. SA1-8-L Water Levels

The average water level at SA4-5-L from the annual sampling events is $155 \mathrm{ft} \mathrm{msl}$ (Figure 35). The lowest water level was in September 2007 at $154 \mathrm{ft}$ msl, and the highest was in March 2010 at $156 \mathrm{ft}$ msl.

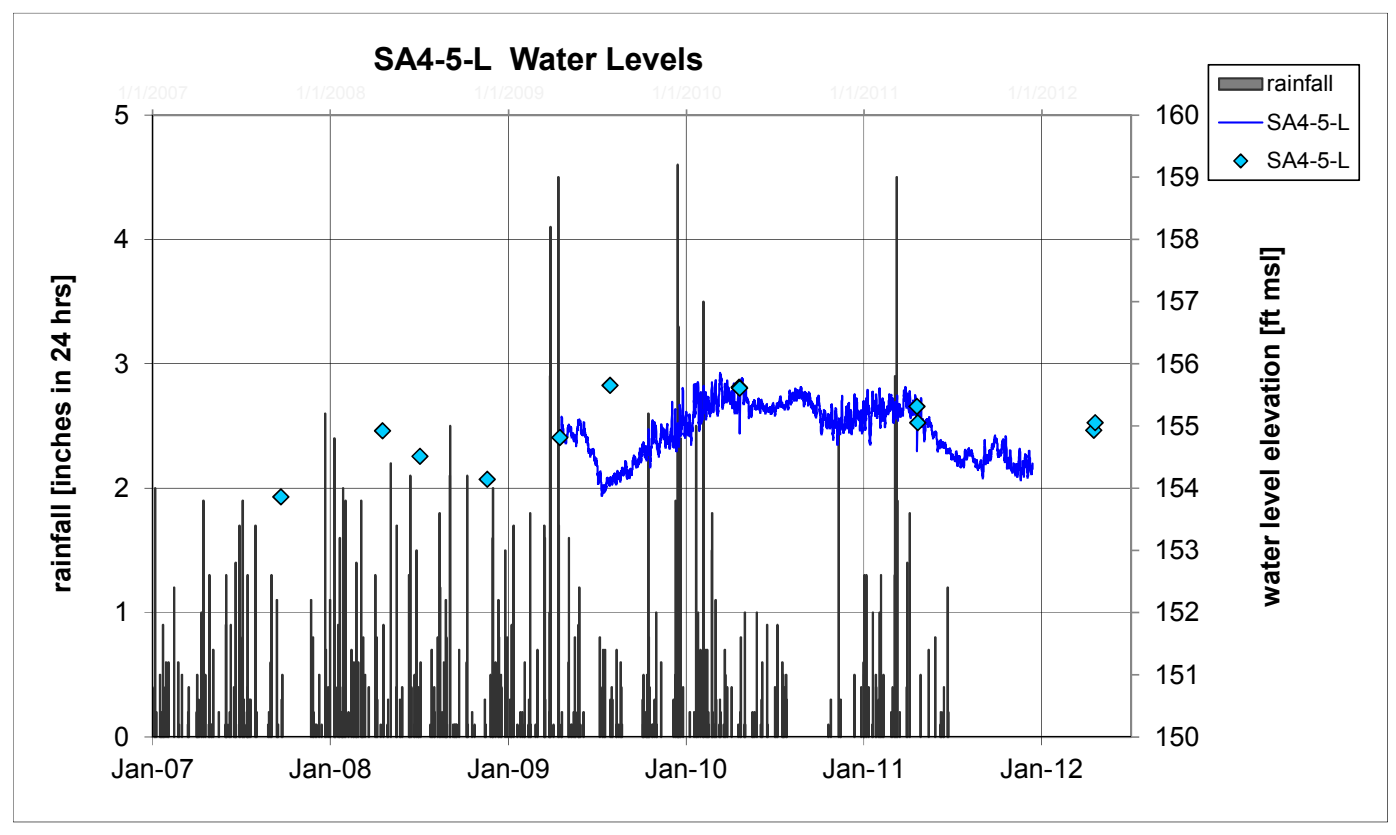

Figure 35. SA4-5-L Water Levels 
Transducers will be added to all SGZ wells to monitor water level fluctuations and the pressure response in successively deeper aquifers (Figure 28). This will allow seasonal and long-term variability for each of the aquifers to be assessed and the vertical gradients between aquifers at SGZ to be monitored. Aquifer 4 well SA5-5-4 will no longer be monitored. Its water level closely tracks with nearby well SA5-4-4 (Figure 30), which will continue to be monitored with a transducer. The batteries in several transducers failed during the monitoring period and will be replaced with newer model transducers with longer battery life. Table 8 lists the wells that will be equipped with transducers and their projected status. A Baro Troll, for recording barometric pressure, and a backup transducer will also be located onsite. The precipitation data presented in Figures 29, 31, 32, 33, 34, and 35 is from the Purvis station, which is 10 miles east of the site. A rain gage will be added at the site to record rainfall, providing a record of site precipitation that can be compared to water level fluctuations.

Table 8. Status of Pressure Transducers for Recording Water Levels at Wells

\begin{tabular}{|c|c|c|c|c|}
\hline Well & Aquifer & Location & Transducer Model & Transducer Status \\
\hline HM-S & Alluvial & SGZ & TROLL 300, 100 psi & Add in 2013 \\
\hline HM-L & Local & SGZ & TROLL 300, 100 psi & Replaces TROLL 4000 \\
\hline $\mathrm{HM}-1$ & 1 & SGZ & TROLL 300, 100 psi & Add in 2013 \\
\hline $\mathrm{HM}-2 \mathrm{~A}$ & $2 \mathrm{~A}$ & SGZ & TROLL 300, 100 psi & Add in 2013 \\
\hline $\mathrm{HM}-2 \mathrm{~B}$ & $2 \mathrm{~B}$ & SGZ & TROLL 300, 100 psi & $\begin{array}{l}\text { Move from SA5-5-4 } \\
\text { in } 2013\end{array}$ \\
\hline $\mathrm{HM}-3$ & 3 & SGZ & TROLL 300, 100 psi & Add in 2013 \\
\hline SA2-2-L & Local & $2,500 \mathrm{ft} \mathrm{NE}$ of $\mathrm{SGZ}$ & $\begin{array}{l}\text { TROLL } 500,30 \text { psi, } \\
\text { vented direct } \\
\text { read cable }\end{array}$ & No change \\
\hline SA1-8-L & Local & $1,600 \mathrm{ft} \mathrm{SE}$ of SGZ & TROLL 300, 100 psi & Replaces TROLL 4000 \\
\hline SA4-5-L & Local & $2,000 \mathrm{ft}$ SW of SGZ & TROLL 300, 100 psi & Add in 2013 \\
\hline HM-L2 & Local & $2,400 \mathrm{ft}$ W of SGZ & TROLL 300, 100 psi & Replaces TROLL 4000 \\
\hline SA5-4-4 & 4 & $6,000 \mathrm{ft}$ SW of SGZ & TROLL 300, 100 psi & No change \\
\hline SA2-4-L & Local & $2,700 \mathrm{ft}$ NNE of SGZ & TROLL 300, $30 \mathrm{psi}$ & Replaces TROLL 4000 \\
\hline SA5-5-4 & 4 & $6,400 \mathrm{ft}$ SW of SGZ & - & Move to HM-2B in 2013 \\
\hline
\end{tabular}

\subsection{Assessment of Sampling Regime}

The sampling regime consists of annual monitoring of the network and analysis of water samples for a large number of analytes. This section describes the suite of analyses and the recommended changes to the analyte list or the frequency or locations of sampling. The evaluation and recommendations are based on analysis of LM's monitoring results from 2007 through 2011. The EPA monitoring data from 1972-2006 was not included in this analysis; because this analysis is focused on LM's current management of the site, and developing an efficient and protective long-term monitoring network based on current site conditions. Table 9 shows the monitoring network, the analytes monitored at each location, whether an analyte was detected, and whether it exceeded an MCL. 
Table 9. Sampling Results 2007-2011

\begin{tabular}{|c|c|c|c|c|c|c|c|c|c|c|c|c|c|c|c|c|c|}
\hline \multirow[t]{2}{*}{ Location } & \multirow{2}{*}{$\begin{array}{c}\text { Year } \\
\text { Location } \\
\text { Established }\end{array}$} & \multirow[t]{2}{*}{ Area } & \multirow{2}{*}{$\begin{array}{l}\text { Location } \\
\text { Type }\end{array}$} & \multirow[t]{2}{*}{ Aquifer } & \multicolumn{3}{|c|}{$\begin{array}{c}\text { VOCs (TCE } 5 \mu \mathrm{g} / \mathrm{L}, \\
\text { cis-1,2 DCE } 70 \mu \mathrm{g} / \mathrm{L}, \\
\text { trans-1,2 DCE } 100 \mu \mathrm{g} / \mathrm{L}, \\
\text { Vinyl Chloride } 2 \mu \mathrm{g} / \mathrm{L} \text { ) }\end{array}$} & \multicolumn{3}{|c|}{ Metals (Sb, As, Ba, Be, Cd, Cr, Pb, Hg ,Ni, Se, Ag, Zn) } & \multicolumn{2}{|c|}{$\begin{array}{l}\text { Tritium (result } \\
>2 \times \text { uncertainty) }\end{array}$} & \multicolumn{2}{|c|}{$\begin{array}{l}\text { Enriched Tritium } \\
\text { Method (result } \\
>2 \times \text { uncertainty) }\end{array}$} & \multirow{2}{*}{\begin{tabular}{|c|}
$\begin{array}{c}\text { Tritium } \\
(20,000 \mathrm{pC} / / \mathrm{L})\end{array}$ \\
Over MCL \\
$\mathbf{2 0 0 7 - 2 0 1 1}$ \\
\end{tabular}} & \multicolumn{2}{|c|}{$\begin{array}{c}\text { Gamma Spec 19 } \\
\text { natural and fission } \\
\text { isotopes (result } \\
>3 \times \text { uncertainty) } \\
>3\end{array}$} \\
\hline & & & & & $\begin{array}{c}\text { Sampled } \\
2012\end{array}$ & \begin{tabular}{|r|} 
Detected \\
$2007-2011$ \\
\end{tabular} & \begin{tabular}{|c|} 
Over MCL \\
$2007-2011$ \\
\end{tabular} & $\begin{array}{c}\text { Sampled } \\
2012\end{array}$ & $\begin{array}{c}\text { Detected 2007-2011 (result } \\
>5 \times \text { detection limit) }\end{array}$ & $\begin{array}{c}\text { Over MCL } \\
\text { 2007-2011 } \\
\end{array}$ & \begin{tabular}{|c|} 
Sampled \\
2012
\end{tabular} & \begin{tabular}{|c|} 
Detected \\
2007-2011 \\
\end{tabular} & \begin{tabular}{|c|} 
Sampled \\
2012 \\
\end{tabular} & \begin{tabular}{|c|} 
Detected \\
$2007-2011$ \\
\end{tabular} & & \begin{tabular}{|c|} 
Sampled \\
2012
\end{tabular} & \begin{tabular}{|c|} 
Detected \\
2007-2011 \\
\end{tabular} \\
\hline $\mathrm{HMH}-16 \mathrm{R}$ & 2002 & SA1 & Well & Alluvial & Yes & No & No & Yes & $\mathrm{As}, \mathrm{Ba}, \mathrm{Pb}, \mathrm{Zn}^{\mathrm{a}}$ & No & Yes & No & Yes & $\begin{array}{l}2007,2009 \\
2010\end{array}$ & No & No & No \\
\hline HMH-5R & 2002 & SA1 & Well & Alluvial & Yes & Yes & TCE, cis DCE & Yes & $\mathrm{Sb}^{\mathrm{a}}, \mathrm{As}, \mathrm{Ba}, \mathrm{Pb}, \mathrm{Zn}$ & No & Yes & $2007-2011$ & No & No & No & No & No \\
\hline HM-S & 1979 & SA1 & Well & Alluvial & Yes & Yes & No & Yes & As, $\mathrm{Ba}, \mathrm{Pb}, \mathrm{Zn}^{\mathrm{a}}$ & No & Yes & $2007-2011$ & No & 2007,2009 & No & Yes & No \\
\hline SA1-12-H & 2002 & SA1 & Well & Alluvial & Yes & No & No & Yes & $\mathrm{As}, \mathrm{Ba}, \mathrm{Cr}^{\mathrm{a}}, \mathrm{Ni}, \mathrm{Zn}$ & No & Yes & No & No & No & No & No & No \\
\hline SA1-1-H & 1995 & SA1 & Well & Alluvial & Yes & Yes & TCE & Yes & $\mathrm{As}, \mathrm{Ba}, \mathrm{Pb}^{\mathrm{a}}, \mathrm{Zn}^{\mathrm{a}}$ & No & Yes & $2007-2011$ & No & No & No & No & No \\
\hline SA1-2-H & 1995 & SA1 & Well & Alluvial & Yes & Yes & \begin{tabular}{|l|} 
Vinyl Chloride \\
\end{tabular} & Yes & $\mathrm{As}, \mathrm{Ba}, \mathrm{Pb}, \mathrm{Zn}^{\mathrm{a}}$, & No & Yes & \begin{tabular}{|l|}
$2007-2011$ \\
\end{tabular} & No & No & No & No & No \\
\hline SA1-3-H & 1995 & SA1 & Well & Alluvial & Yes & Yes & No & Yes & $\mathrm{Sb}^{\mathrm{a}}, \mathrm{As}, \mathrm{Ba}, \mathrm{Cr}, \mathrm{Pb}, \mathrm{Se}^{\mathrm{a}}, \mathrm{Zn}$ & $\begin{array}{l}\text { As (2007- } \\
2011)\end{array}$ & Yes & $2008-2011$ & No & 2008,2009 & No & No & No \\
\hline SA1-4-H & 1995 & SA1 & Well & Alluvial & Yes & Yes & No & Yes & $\mathrm{As}, \mathrm{Ba}, \mathrm{Zn}^{\mathrm{a}}$, & No & Yes & No & No & \begin{tabular}{|l|}
2007,2010 \\
\end{tabular} & No & No & No \\
\hline SA1-5-H & 1995 & SA1 & Well & Alluvial & Yes & Yes & No & Yes & $\mathrm{As}, \mathrm{Ba}, \mathrm{Se}, \mathrm{Zn}$ & No & Yes & No & Yes & No & No & No & No \\
\hline SA1-6-H & 1995 & SA1 & Well & Alluvial & Yes & No & No & Yes & $\begin{array}{c}\mathrm{Sb}^{\mathrm{a}}, \mathrm{As}, \mathrm{Ba}, \mathrm{Cd}^{\mathrm{a}}, \mathrm{Cr}^{\mathrm{a}}, \mathrm{Pb}, \\
\mathrm{Hg}^{\mathrm{a}}, \mathrm{Zn}\end{array}$ & As, $\mathrm{Pb}(2007)$ & Yes & No & No & 2007,2010 & No & No & No \\
\hline SA1-7-H & 1995 & SA1 & Well & Alluvial & Yes & Yes & No & Yes & $\mathrm{As}, \mathrm{Ba}, \mathrm{Se}, \mathrm{Zn}^{\mathrm{a}}$ & $\begin{array}{l}\text { As (2010, } \\
\text { 2011) }\end{array}$ & Yes & No & Yes & No & No & No & No \\
\hline SA3-4-H & 1995 & SA3 & Well & Alluvial & Yes & No & No & Yes & $\mathrm{As}, \mathrm{Ba}, \mathrm{Pb}, \mathrm{Zn}$ & No & Yes & No & No & 2007 & No & No & No \\
\hline $\mathrm{HM}-1$ & 1979 & SA1 & Well & Aquifer 1 & No & NA & NA & No & NA & NA & Yes & No & Yes & 2009 & No & Yes & No \\
\hline HM-2A & 1979 & SA1 & Well & Aquifer 2a & No & NA & NA & No & NA & NA & Yes & No & Yes & No & No & Yes & No \\
\hline HM-2B & 1979 & SA1 & Well & Aquifer $2 b$ & No & NA & NA & No & NA & NA & Yes & 2008 & Yes & No & No & Yes & No \\
\hline SA3-11-3 & 1996 & SA3 & Well & Aquifer 3a & No & NA & NA & No & NA & NA & Yes & No & No & No & No & Yes & No \\
\hline HM-3 & 1979 & SA1 & Well & Aquifer $3 b$ & No & NA & NA & Yes & $\mathrm{Sb}^{\mathrm{a}}, \mathrm{As}, \mathrm{Ba}, \mathrm{Cr}, \mathrm{Pb}, \mathrm{Zn}$ & $\operatorname{Cr}(2007-2011)$ & Yes & 2008 & Yes & No & No & Yes & No \\
\hline SA1-11-3 & 1996 & SA1 & Well & Aquifer 3b & No & NA & NA & No & NA & NA & Yes & No & No & No & No & Yes & No \\
\hline SA5-4-4 & 1996 & SA5 & Well & \begin{tabular}{|l|l} 
Aquifer 4 \\
\end{tabular} & No & NA & NA & No & NA & $\mathrm{NA}$ & Yes & No & Yes & No & No & Yes & No \\
\hline SA5-5-4 & 1996 & SA5 & Well & Aquifer 4 & No & NA & NA & No & NA & NA & Yes & No & Yes & No & No & Yes & No \\
\hline $\mathrm{E}-7$ & 1972 & SA3 & Well & Caprock & Yes & No & No & No & NA & NA & Yes & No & No & No & No & Yes & No \\
\hline HM-L & 1979 & SA1 & Well & Local & No & NA & NA & Yes & $\mathrm{As}, \mathrm{Ba}, \mathrm{Cr}^{\mathrm{a}}$ & No & Yes & 2008-2011 & No & No & No & Yes & No \\
\hline SA1-8-L & 1997 & SA1 & Well & Local & No & NA & NA & Yes & $\mathrm{As}, \mathrm{Ba}, \mathrm{Zn}$, & No & Yes & No & Yes & No & No & Yes & No \\
\hline SA2-1-L & 1996 & SA2 & Well & Local & No & NA & NA & Yes & $\mathrm{Sb}, \mathrm{As}, \mathrm{Ba}, \mathrm{Pb}, \mathrm{Se}, \mathrm{Zn}$ & As (2007) & Yes & No & No & No & No & Yes & No \\
\hline SA2-2-L & 1996 & SA2 & Well & Local & No & $\mathrm{NA}$ & $\mathrm{NA}$ & Yes & $\mathrm{Sb}, \mathrm{As}, \mathrm{Ba}, \mathrm{Cr}, \mathrm{Pb}, \mathrm{Se}, \mathrm{Zn}$ & No & Yes & No & No & No & No & Yes & No \\
\hline SA2-4-L & 1996 & SA2 & Well & Local & No & NA & NA & Yes & $\mathrm{Sb}^{\mathrm{a}}, \mathrm{As}, \mathrm{Ba}, \mathrm{Pb}, \mathrm{Zn}^{\mathrm{a}}$ & No & Yes & No & No & No & No & Yes & No \\
\hline HM-L2 & & SA4 & Well & Local & No & $\mathrm{NA}$ & $\mathrm{NA}$ & Yes & $\mathrm{As}, \mathrm{Ba}, \mathrm{Pb}^{\mathrm{a}}, \mathrm{Zn}^{\mathrm{a}}$ & No & Yes & No & No & No & No & Yes & No \\
\hline SA4-5-L & 2002 & SA4 & Well & Local & No & NA & NA & Yes & $\mathrm{Sb}, \mathrm{As}, \mathrm{Ba}, \mathrm{Cr}, \mathrm{Pb}, \mathrm{Se}, \mathrm{Zn}$ & $\begin{array}{l}\mathrm{Ba}(2008- \\
2011)\end{array}$ & Yes & No & No & No & No & Yes & No \\
\hline HickHCrTSD-East & 2008 & os & Surface & $\begin{array}{l}\text { Surface } \\
\text { Water }\end{array}$ & No & NA & NA & Yes & $\mathrm{As}, \mathrm{Ba}, \mathrm{Pb}$ & No & Yes & No & No & No & No & Yes & No \\
\hline $\begin{array}{l}\text { Half Moon Cr. } \\
\text { Overflow }\end{array}$ & 1972 & SA1 & Surface & $\begin{array}{l}\text { Surface } \\
\text { Water }\end{array}$ & No & NA & NA & Yes & $\mathrm{As}, \mathrm{Ba}, \mathrm{Cr}, \mathrm{Pb}, \mathrm{Se}, \mathrm{Zn}$ & No & Yes & No & No & 2008 & No & Yes & No \\
\hline Half Moon Creek & 1972 & SA1 & Surface & $\begin{array}{l}\text { Surface } \\
\text { Water }\end{array}$ & No & NA & NA & Yes & $\mathrm{As}, \mathrm{Ba}, \mathrm{Pb}, \mathrm{Zn}^{\mathrm{a}}$ & No & Yes & No & No & 2007 & No & Yes & No \\
\hline Pond West of SGZ & 1972 & SA1 & Surface & $\begin{array}{l}\text { Surface } \\
\text { Water }\end{array}$ & No & NA & NA & Yes & $\mathrm{As}, \mathrm{Ba}, \mathrm{Cd}^{\mathrm{a}}, \mathrm{Cr}^{\mathrm{a}}, \mathrm{Pb}, \mathrm{Zn}$ & No & Yes & No & No & 2008,2010 & No & Yes & No \\
\hline
\end{tabular}


Table 9 (continued). Sampling Results 2007-2011

\begin{tabular}{|c|c|c|c|c|c|c|c|c|c|c|c|c|c|c|c|c|c|}
\hline \multirow{2}{*}{$\begin{array}{c}\text { Location } \\
\text { REECo Pit (A) } \\
\end{array}$} & \multirow{2}{*}{\begin{tabular}{|c|}
$\begin{array}{c}\text { Year } \\
\text { Location } \\
\text { Established }\end{array}$ \\
1980 \\
\end{tabular}} & \multirow{2}{*}{\begin{tabular}{|l|} 
Area \\
SA2 \\
\end{tabular}} & \multirow{2}{*}{$\begin{array}{c}\begin{array}{c}\text { Location } \\
\text { Type }\end{array} \\
\text { Surface } \\
\end{array}$} & \multirow{2}{*}{$\begin{array}{c}\text { Aquifer } \\
\begin{array}{c}\text { Surface } \\
\text { Water }\end{array} \\
\end{array}$} & \multicolumn{3}{|c|}{$\begin{array}{c}\text { VOCs (TCE } 5 \mu \mathrm{g} / \mathrm{L}, \\
\text { cis-1,2 DCE } 70 \mu \mathrm{g} / \mathrm{L}, \\
\text { trans-1,2 DCE } 100 \mathrm{\mu g} / \mathrm{L}, \\
\text { Vinyl Chloride } 2 \mathrm{\mu g} / \mathrm{L} \text { ) } \\
\end{array}$} & \multicolumn{3}{|c|}{ Metals (Sb, As, Ba, Be, Cd, Cr, Pb, Hg , Ni, Se, Ag, Zn) } & \multicolumn{2}{|c|}{$\begin{array}{c}\text { Tritium (result } \\
>2 \times \text { uncertainty) }\end{array}$} & \multicolumn{2}{|c|}{$\begin{array}{l}\text { Enriched Tritium } \\
\text { Method (result } \\
>2 \times \text { uncertainty) }\end{array}$} & \multirow{2}{*}{\begin{tabular}{|c|}
$\begin{array}{c}\text { Tritium } \\
(20,000 \mathrm{pC} / \mathrm{L})\end{array}$ \\
No \\
\end{tabular}} & \multicolumn{2}{|c|}{$\begin{array}{c}\text { Gamma Spec 19 } \\
\text { natural and fissior } \\
\text { isotopes (result } \\
>3 \times \text { uncertainty) } \\
\end{array}$} \\
\hline & & & & & No & NA & NA & Yes & $\mathrm{Sb}^{\mathrm{a}}, \mathrm{As}, \mathrm{Ba}^{\mathrm{a}}, \mathrm{Cr}^{\mathrm{a}}, \mathrm{Pb}, \mathrm{Zn}^{\mathrm{a}}$ & No & Yes & No & No & 2008 & & No & No \\
\hline REECo Pit (B) & 1980 & SA2 & Surface & $\begin{array}{l}\text { Surface } \\
\text { Water }\end{array}$ & No & NA & NA & Yes & As, Ba, $\mathrm{Cr}, \mathrm{Pb}, \mathrm{Zn}$ & No & Yes & 2007,2009 & No & 2010 & No & No & No \\
\hline REECo Pit (C) & 1980 & SA2 & Surface & $\begin{array}{c}\text { Surface } \\
\text { Water }\end{array}$ & No & NA & NA & Yes & As, $\mathrm{Ba}, \mathrm{Cr}, \mathrm{Pb}, \mathrm{Zn}$ & No & Yes & No & No & 2008 & No & No & No \\
\hline Grantham Cr. Entry & 2008 & SB & Surface & $\begin{array}{c}\text { Surface } \\
\text { Water }\end{array}$ & No & NA & NA & Yes & $\mathrm{As}, \mathrm{Ba}, \mathrm{Pb}, \mathrm{Zn}^{\mathrm{a}}$ & No & Yes & No & No & No & No & Yes & No \\
\hline Half Moon Cr. Entry & 2008 & SB & Surface & $\begin{array}{l}\text { Surface } \\
\text { Water }\end{array}$ & No & NA & NA & Yes & $\mathrm{As}, \mathrm{Ba}, \mathrm{Pb}, \mathrm{Zn}$ & No & Yes & No & No & No & No & Yes & No \\
\hline Half Moon Cr. Exit & 2008 & SB & Surface & $\begin{array}{l}\text { Surface } \\
\text { Water }\end{array}$ & No & NA & NA & Yes & $\mathrm{As}, \mathrm{Ba}, \mathrm{Pb}, \mathrm{Zn}^{\mathrm{a}}$ & No & Yes & No & No & No & No & Yes & No \\
\hline $\begin{array}{l}\text { Hickory Hollow Cr. } \\
\text { Entry }\end{array}$ & 2008 & SB & Surface & $\begin{array}{l}\text { Surface } \\
\text { Water }\end{array}$ & No & NA & NA & Yes & $\mathrm{As}, \mathrm{Ba}, \mathrm{Pb}$ & No & Yes & No & No & No & No & Yes & No \\
\hline
\end{tabular}

analyte detected only once during 2007-2011

orange highlighted cells $=$ analytes and date over MC

\section{Abbreviations}

$\mathrm{SB}=$ site boundary 


\subsection{Metals}

Metals currently analyzed are antimony, arsenic, barium, beryllium, cadmium, chromium, lead, mercury, nickel, selenium, silver, and zinc. The locations that are sampled are all Alluvial Aquifer wells (SA1, SA3), all Local Aquifer wells (SA1, SA2, and SA4), Aquifer 3 well HM-3 (SA1), and all of the surface water locations. Of the metals analyzed, beryllium, nickel, and silver have not been detected, mercury $(\mathrm{Hg})$ was only detected once in SA1-6-H, and cadmium was detected once in SA1-6-H and once in the Beaver Pond. Selenium has been detected in seven of the wells but has not exceeded the MCL. Zinc has been detected in a majority of the wells at low levels. Concentrations of arsenic, barium, chromium, and lead have all exceeded the MCL in at least one well from 2007 through 2011. These four metals were also detected at the greatest frequency during the 1993 CPT and also exceeded the MCLs at that time. It is recommended that the metals sampling suite be reduced to these four metals (As, $\mathrm{Ba}, \mathrm{Cr}$, and $\mathrm{Pb}$ ), which continue to persist in site waters at levels above their MCLs. It is also recommended that the other two Aquifer 3 wells (SA1-11-3 and SA3-11-3) be analyzed for these metals since they have been detected in well HM-3.

\section{$5.2 \quad$ VOCs}

VOCs analysis comprises a suite of 69 VOCs, including TCE, cis- and trans-1,2-DCE, and vinyl chloride. VOCs are analyzed in all the Alluvial Aquifer wells and in E7, the Caprock Aquifer well. The historical descriptions of waste disposal activities and the 1993 CPT results did not show these VOCs present in SA3, and they have not been detected to date in well E7; therefore, it is recommended that VOCs be dropped from the monitoring at well E7.

Because the Alluvial Aquifer potentially has a downward gradient, and the distribution of the degradation products within the aquifer is not fully understood, it is recommended that VOC analysis be extended to the Local Aquifer wells and to select surface water sampling sites for at least one sampling event to determine whether TCE and its degradation products are limited to the Alluvial Aquifer. It is recommended that all the Local Aquifer wells be sampled for VOCs, including SA2 wells on the east side of Half Moon Creek, as organic compounds were detected in this area during the 1993 remedial investigation (Table 2). The recommended surface water locations are the REECo Disposal Pits locations, the Pond West of SGZ, Half Moon Creek, and Half Moon Creek Overflow.

\subsection{Tritium}

Tritium is analyzed in all of the onsite wells, and 25 percent of the samples are chosen randomly each year for analysis by the enriched method. The enriched method allows for a lower detection limit (3-4 pCi/L) compared to the standard method (300-400 pCi/L). Because tritium has a relatively short half-life (12.32 years), concentrations will continue to decrease in site water and will eventually fall below detection limits for both methods. Tritium is monitored both for surface contamination and for any potential future migration from the shot cavity. It is recommended that the tritium analysis on all samples and the 25-percent rotation on the enriched method continue, until residual surface contamination is no longer detected. Once tritium is no longer detected from surface contamination it is recommended that sampling be reduced to just the areas that overlie a potential contaminant source 
(indicator wells); i.e., five SGZ wells (HM-L, HM-1, HM-2A, HM-2B, and HM-3);

Caprock Aquifer well E7 (although it is not directly over the cavity, it is the only well in the

Caprock Aquifer); and the Aquifer 4 wells, which should be monitored because of their location over the Aquifer 5 injection site.

\subsection{Gamma Spectroscopy}

Radionuclides are currently analyzed by gamma spectroscopy in samples from the following: all the wells over the shot cavity (except for Alluvial Aquifer well HM-S), the Aquifer 3 wells, the Aquifer 4 wells, the SA2 wells, the Caprock Aquifer well, and all surface water locations (except for the REECo Disposal Pits area). Isotopes that are currently analyzed are actinium-228, americium-241, antimony-125, cerium-144, cesium-134, cesium-137, cobalt-60, europium-152, europium-154, europium-155, lead-212, potassium-40, promethium-144, promethium-146, ruthenium-106, thorium-234, uranium-235, uranium-238, and yttrium-88.

Contaminant migration from the shot cavity and Aquifer 5 are highly unlikely; however, to be conservative, monitoring for radionuclides should continue onsite. It is recommended that gamma spectroscopy analysis be reduced to just the indicator wells.

\subsection{Chlorine-36 Analysis}

Because tritium has a short half-life (12.32 years) and therefore will not be a viable long-term indicator of contaminate migration, chlorine-36 analysis is being considered as a replacement for tritium analysis. The detonation was conducted in salt and because of its long half-life (301,000 years) chlorine-36 would be an ideal indicator of radionuclide migration from the shot cavity or Aquifer 5, which is a salt water aquifer. Chlorine is also typically used as a conservative tracer so chlorine-36 should have similar transport properties to tritium and therefore would be any early indicator of contaminate migrations as opposed to cesium-137 (gamma spectroscopy analysis). The probability of contaminant migration is low and, if it did occur, the areas that directly overlie a source would be the first locations where contaminants would be detected. Therefore it is recommended that chlorine-36 be analyzed in samples from the six SGZ wells (HM-S, HM-L, HM-1, HM-2A, HM-2B, and HM-3), Caprock Aquifer well E7 (although it is not directly over the cavity, it is the only well in the Caprock Aquifer), and the Aquifer 4 wells, which should be monitored because of their location over the Aquifer 5 injection site. Because the likelihood of contaminant migration is very low, chlorine-36 analysis should be conducted during every other sampling event (April). Because this is a new analysis for the site, the Local Aquifer and Aquifer 3 wells should be analyzed for chlorine-36 for one sampling event to supply baseline results for the site. The Alluvial Aquifer wells should not be analyzed for chlorine-36 except for HM-S at SGZ, and this well should be sampled only during the first sampling event (2013) to establish baseline levels in the Alluvial Aquifer.

\subsection{Conclusions and Recommendations}

The Salmon site monitoring network monitors onsite aquifers for both current contaminants and indicators of future contaminant migration. This report has evaluated the monitoring locations within the hydrologic system and the types of analytes. This section describes an optimized 
sampling regime and provides suggestions for improving the monitoring network coverage on the site.

\subsection{Optimized Sampling Regime}

This section summarizes the changes recommended in previous sections and discusses the costs associated with implementing the changes. Table 10 shows the recommended analyses and estimated costs.

Table 10. Salmon Site Analysis Costs

\begin{tabular}{|c|c|c|c|c|}
\hline Analyte Type & Analyte & Analysis & Cost & Unit Cost \\
\hline \multirow{2}{*}{ Radionuclide } & \multirow{2}{*}{ Tritium } & Standard method & $\$ 51.00$ & Per sample \\
\hline & & Enriched method & $\$ 318.00$ & Per sample \\
\hline Radionuclide & $\begin{array}{l}\text { Actinium-228, americium-241, } \\
\text { antimony-125, cerium-144, cesium-134, } \\
\text { cesium-137, cobalt-60, europium-152, } \\
\text { europium-154, europium-155, lead-212, } \\
\text { potassium-40, promethium-144, } \\
\text { promethium-146, ruthenium-106, } \\
\text { thorium-234, uranium-235, uranium-238, } \\
\text { yttrium-88 }\end{array}$ & $\begin{array}{c}\text { Gamma } \\
\text { spectroscopy }\end{array}$ & $\$ 76.00$ & Per sample \\
\hline Radionuclide & Chlorine -36 & & $\$ 855.00$ & Per sample \\
\hline \multirow{2}{*}{ Metals } & \multirow{2}{*}{$\begin{array}{l}\text { Barium, beryllium, chromium, nickel, } \\
\text { silver, zinc }\end{array}$} & \multirow{2}{*}{ ICP } & $\$ 17.00$ & Per analyte \\
\hline & & & $\$ 102.00$ & Per sample \\
\hline \multirow{2}{*}{ Metals } & \multirow{2}{*}{$\begin{array}{l}\text { Antimony, arsenic, cadmium, lead, } \\
\text { selenium }\end{array}$} & \multirow{2}{*}{ ICP-MS } & $\$ 22.00$ & Per analyte \\
\hline & & & $\$ 110.00$ & Per sample \\
\hline VOCs & $\begin{array}{l}69 \text { VOCs, including: trichloroethene, } \\
\text { cis- and trans-1,2-dichloroethene, and } \\
\text { vinyl chloride }\end{array}$ & 8260 Low Level & $\$ 105.00$ & Per sample \\
\hline
\end{tabular}

\section{Abbreviations:}

ICP = inductively coupled plasma emission spectrometer ICP-MS = inductively coupled plasma-mass spectrometer

The current sampling regime analyses cost $\$ 17,105$. The cost breakdown is as follows: 25 (27) gamma spectroscopy $(\$ 2,148), 39$ (41) tritium $(\$ 2,121), 10$ enriched tritium $(\$ 3,183), 186(238)$ inductively coupled plasma emission spectrometer (ICP) metals (\$3,927), 155 (170) inductively coupled plasma-mass spectrometer (ICP-MS) metals $(\$ 3,740)$ and 13 VOC samples $(\$ 1,986)$. These costs include duplicate samples for quality assurance; numbers in parenthesis are the total including the duplicates, and the cost includes the duplicates.

The proposed changes to the sampling regime are:

- $\quad$ Switch sampling to an 18-month rotation to capture seasonal site differences. Sampling events will occur in April and October. April events will include VOCs, metals, tritium gamma spectroscopy, and chlorine-36. October events will only include VOCs, metals and tritium.

- $\quad$ Reduce the number of metals analyzed and add metals analysis to two additional wells (Aquifer 3).

- $\quad$ Expand VOCs analysis to the Local Aquifer wells and six surface locations for at least one sampling event, and remove VOCs analysis from the Caprock Aquifer well. 
- Add chlorine-36 analysis to the wells in areas of higher probability for radiological contaminant migration, and do that monitoring every other sampling event (i.e., April events).

- Reduce gamma spectroscopy analysis to just the wells in areas of higher probability for radiological contaminant migration, and do that monitoring every other sampling event (i.e., April events).

- Add oxidation reduction potential and dissolved oxygen to the field measurements.

- Once surface tritium contamination has attenuated, reduce tritium analysis to the indicator wells and half-moon creek exit.

Table 11 shows the proposed sampling regime. The costs associated with this regime would be $\$ 18,806$. The cost breakdown is 8 gamma spectroscopy samples $(\$ 608), 39$ (41) tritium samples $(\$ 2,121), 10$ enriched tritium samples $(\$ 3,183), 66$ ICP metals samples $(\$ 1,122)$, 66 ICP-MS metals samples (\$1,452), 25 VOC samples $(\$ 2,625)$, and 9 chlorine-36 samples $(\$ 7,695)$. This breakdown includes only the duplicates for tritium, as no change to tritium sampling was recommended. The proposed sampling regime would cost $\$ 1,701$ more than the current regime.

Ultimately, these recommendations would produce more meaningful data, which would better characterize the site contamination and provide protective long-term monitoring without a significant cost increase. 
Table 11. Proposed Sampling Regime

\begin{tabular}{|c|c|c|c|c|c|c|c|}
\hline \multirow{2}{*}{\begin{tabular}{|r|} 
Subsurface Source Area \\
Well Name \\
\end{tabular}} & \multirow[b]{2}{*}{ TD (ft.) } & \multicolumn{5}{|c|}{ Sample Analytes } & \multirow{2}{*}{ Water Level } \\
\hline & & VOC & Metals $^{a}$ & Tritium $^{\mathrm{b}}$ & Gamma Spec & Chlorine-36 & \\
\hline \multicolumn{8}{|l|}{ Source Area 1} \\
\hline SA1-1-H & 30 & $\mathrm{X}$ & $\mathrm{X}$ & $\mathrm{X}$ & & & $\mathrm{X}$ \\
\hline SA1-2-H & 30 & $\mathrm{X}$ & $\mathrm{X}$ & $x$ & & & $\mathrm{X}$ \\
\hline SA1-3-H & 30 & $\mathrm{X}$ & $x$ & $\mathrm{X}$ & & & $\mathrm{X}$ \\
\hline SA1-4-H & 30 & $\mathrm{x}$ & $\mathrm{X}$ & $\mathrm{X}$ & & & $\mathrm{X}$ \\
\hline SA1-5-H & 30 & $x$ & $\mathrm{X}$ & $\mathrm{X}$ & & & $\mathrm{X}$ \\
\hline SA 1-6-H & 23 & $\mathrm{X}$ & $\mathrm{X}$ & $\mathrm{X}$ & & & $x$ \\
\hline SA1-7-H & 30 & $\mathrm{x}$ & $\mathrm{x}$ & $\mathrm{x}$ & & & $\mathrm{X}$ \\
\hline SA1-12-H & 30 & $\mathrm{X}$ & $\mathrm{X}$ & $\mathrm{X}$ & & & $\mathrm{X}$ \\
\hline $\mathrm{HMH}-5 \mathrm{R}$ & 30 & $\mathrm{x}$ & $\mathrm{X}$ & $\mathrm{X}$ & & & $\mathrm{X}$ \\
\hline $\mathrm{HMH}-16 \mathrm{R}$ & 30 & $x$ & $\mathrm{x}$ & $\mathrm{x}$ & & & $\mathrm{X}$ \\
\hline $\mathrm{HM}-\mathrm{S}$ & 30 & $\mathrm{X}$ & $\mathrm{X}$ & $\mathrm{X}$ & $\mathrm{O}$ & $X^{d}$ & $\mathrm{X}$ \\
\hline SA1-8-L & 195 & $X^{c}$ & $\mathrm{X}$ & $\mathrm{X}$ & $\mathrm{O}$ & & $\mathrm{X}$ \\
\hline HM-L & 204 & $X^{c}$ & $\mathrm{X}$ & $\mathrm{X}$ & $\mathrm{X}$ & $x$ & $x$ \\
\hline $\mathrm{HM}-1$ & 415 & & & $\mathrm{X}$ & $\mathrm{X}$ & $\mathrm{X}$ & $x$ \\
\hline $\mathrm{HM}-2 \mathrm{~A}$ & 537 & & & $\mathrm{x}$ & $\mathrm{x}$ & $x$ & $x$ \\
\hline $\mathrm{HM}-2 \mathrm{~B}$ & 700 & & & $\mathrm{X}$ & $\mathrm{X}$ & $x$ & $\mathrm{X}$ \\
\hline $\mathrm{HM}-3$ & 875 & & $x$ & $\mathrm{X}$ & $x$ & $x$ & $x$ \\
\hline SA1-11-3 & 924 & & $\mathrm{X}$ & $\mathrm{X}$ & $\mathrm{O}$ & & $x$ \\
\hline \multicolumn{8}{|l|}{ Source Area 2} \\
\hline SA2-1-L & 349 & $X^{c}$ & $\mathrm{X}$ & $\mathrm{X}$ & $\mathrm{O}$ & & $\mathrm{X}$ \\
\hline SA2-2-L & 340 & $X^{c}$ & $x$ & $\mathrm{X}$ & $\mathrm{O}$ & & $x$ \\
\hline SA2-4-L & 250 & $X^{c}$ & $\mathrm{X}$ & $\mathrm{X}$ & $\mathrm{O}$ & & $x$ \\
\hline \multicolumn{8}{|l|}{ Source Area 3} \\
\hline SA3-4-H & 30 & $\mathrm{X}$ & $x$ & $\mathrm{X}$ & & & $\mathrm{X}$ \\
\hline $\mathrm{E}-7$ & 934 & $\mathrm{O}$ & & $x$ & $x$ & $x$ & $x$ \\
\hline SA3-11-3 & 861 & & $x$ & $\mathrm{x}$ & $\mathrm{O}$ & & $x$ \\
\hline \multicolumn{8}{|l|}{ Source Area 4} \\
\hline HM-L2 & 200 & $X^{c}$ & $\mathrm{X}$ & $\mathrm{X}$ & $\mathrm{O}$ & & $x$ \\
\hline SA4-5-L & 180 & $X^{c}$ & $x$ & $x$ & $\mathrm{O}$ & & $x$ \\
\hline \multicolumn{8}{|l|}{ Source Area 5} \\
\hline SA5-4-4 & 2099 & & & $x$ & $\mathrm{X}$ & $x$ & $x$ \\
\hline SA5-5-4 & 2081 & & & $\mathrm{X}$ & $\mathrm{X}$ & $x$ & $\mathrm{X}$ \\
\hline \multicolumn{8}{|l|}{ Surface Location Name } \\
\hline HALFMOON CREEK & NA & & $\mathrm{X}$ & $\mathrm{X}$ & $\mathrm{O}$ & & \\
\hline HALFMOONCRKOVERFLOW & NA & $x^{c}$ & $\mathrm{x}$ & $\mathrm{x}$ & $\mathrm{O}$ & & \\
\hline Pond West of GZ & NA & $X^{c}$ & $\mathrm{X}$ & $\mathrm{X}$ & $\mathrm{O}$ & & \\
\hline REECo Pit $(A)$ & NA & $X^{c}$ & $\mathrm{X}$ & $\mathrm{X}$ & & & \\
\hline REECo Pit (B) & NA & $X^{c}$ & $\mathrm{X}$ & $\mathrm{X}$ & & & \\
\hline REECo Pit (C) & NA & $X^{c}$ & $\mathrm{X}$ & $\mathrm{X}$ & & & \\
\hline Grantham Ck Entry & NA & & $\mathrm{X}$ & $\mathrm{X}$ & $\mathrm{O}$ & & \\
\hline Half Moon Ck Entry & NA & & $\mathrm{X}$ & $\mathrm{X}$ & $\mathrm{O}$ & & \\
\hline Hick Hollow Ck Entry & NA & & $\mathrm{x}$ & $\mathrm{x}$ & $\mathrm{O}$ & & \\
\hline Half Moon Ck Exit & NA & & $\mathrm{X}$ & $\mathrm{X}$ & $\mathrm{O}$ & & \\
\hline HickHCr.tsd_East & $\mathrm{NA}$ & & $\mathrm{X}$ & $\mathrm{x}$ & $\mathrm{O}$ & & \\
\hline
\end{tabular}

Notes: Changes are shown in Red (O indicates a location that will no longer be sampled)

a Metals As, $\mathrm{Ba}, \mathrm{Cr}, \mathrm{Pb}$

${ }^{b}$ Analyze $25 \%$ of the tritium samples by the enriched tritium method

${ }^{c}$ If a nondetect, then discontinue

${ }^{\mathrm{d}}$ Sample only in 2013 


\subsection{Network Locations}

\section{Wells}

The monitoring network at the Salmon site encompasses all of the locations onsite with current contamination or the potential for future contamination. Although a complete understanding of flow directions in all aquifers beneath the site is not necessary, Six additional wells (four in the Local Aquifer and two in the Alluvial Aquifer) are recommended to be installed to better determine flow directions in the Local Aquifer and interactions between the Local and Alluvial Aquifers. Additional Local Aquifer wells north of SGZ on either side of Half Moon Creek, and south of SGZ near wells SA3-4-H and E7 (Figure 36), would help determine if flow in this aquifer is toward the creek and trending north with the creek flow, toward SGZ, or toward SGZ and then south. An Alluvial Aquifer well is recommended to be paired with the Local Aquifer well between Half Moon Creek and the SA2 well and the Local Aquifer well near well E7 (Figure 36). Depending on the elevation at the selected location, the shallow well in SA2 may actually be screened in the Citronelle Formation rather than alluvium. These locations were chosen because they will better define the flow in the Local and Alluvial/Citronelle aquifers and therefore any migration of current contaminant plumes. The locations were also chosen for ease of access; three are near existing wells and the fourth is near an access road. Table 12 describes the proposed well locations, the reasons for the locations, and potential outcome from the new information that the wells will provide.

\section{Surface Water Locations}

The surface water monitoring locations were not fully assessed as part of this report. The creek entry and exit points, which have been sampled only since 2008 , are a logical addition to the network, as knowing the condition of the water entering and leaving the site is useful. The Half Moon Creek Overflow, Half Moon Creek, the Pond West of SGZ, and the REECo Disposal Pits area are historical sampling locations and are in areas of known contamination. It is recommended that, during annual sampling in 2013, the newer locations be assessed for ease of access and for whether alternative locations are available that would provide the same information. If both criteria are met, it may be beneficial to adjust these sampling points. Another recommendation is to determine if the three locations in REECo Pit 5 could be reduced to one location or to a composite sample of the three locations. 
Table 12. Proposed Locations of New Wells at the Salmon Site

\begin{tabular}{|c|c|c|c|c|}
\hline \multicolumn{5}{|c|}{ Proposed Locations of New Wells at the Salmon Site } \\
\hline Location & Aquifer & Reason & Possible Outcomes & Notes \\
\hline $\begin{array}{l}\text { SA1-12-H } \\
\text { Well Pad }\end{array}$ & Local & $\begin{array}{l}\text { Define flows in Local Aquifer to } \\
\text { determine migration pathways } \\
\text { of contaminant plume. }\end{array}$ & $\begin{array}{l}\text { 1) If the water level elevation is } \\
\text { between } 156 \text { and } 153 \mathrm{ft} \text { msl it would } \\
\text { indicate that flow in the Local Aquifer is } \\
\text { toward SGZ. } \\
\text { 2) If the water level elevation is } \\
<153 \mathrm{ft} \mathrm{msl} \text { it would indicate that flow } \\
\text { in the Local Aquifer is potentially } \\
\text { northward. }\end{array}$ & \\
\hline \multirow[t]{2}{*}{$\begin{array}{l}\text { Between Half } \\
\text { Moon Creek and } \\
\text { SA2 Wells }\end{array}$} & Local & $\begin{array}{l}\text { Define flows in Local Aquifer to } \\
\text { determine migration pathways } \\
\text { of contaminant plume. }\end{array}$ & $\begin{array}{l}\text { 1) If the water level elevation is } \\
\text { between } 157 \text { and } 153 \mathrm{ft} \mathrm{msl} \text { it would } \\
\text { indicate that flow in the Local Aquifer is } \\
\text { toward SGZ. } \\
\text { 2) If the water level elevation is } \\
<153 \mathrm{ft} \mathrm{ms} \text { it would indicate that flow in } \\
\text { the Local Aquifer is potentially } \\
\text { northward. }\end{array}$ & \\
\hline & Alluvial & $\begin{array}{l}\text { Determine interactions between } \\
\text { Alluvial and Local aquifers. }\end{array}$ & & \\
\hline $\begin{array}{l}\text { SA3-4-H } \\
\text { Well Pad }\end{array}$ & Local & $\begin{array}{l}\text { Define flows in Local Aquifer to } \\
\text { determine migration pathways } \\
\text { of contaminant plume. }\end{array}$ & $\begin{array}{l}\text { 1) If the water level elevation is } \\
>153 \mathrm{ft} \mathrm{msl} \text { it would indicate that flow in } \\
\text { the Local Aquifer is toward SGZ and } \\
\text { the north. } \\
\text { 2) If the water level elevation is } \\
<153 \mathrm{ft} \mathrm{msl} \text { it would indicate that flow in } \\
\text { the Local Aquifer is south-southwest. }\end{array}$ & $\begin{array}{l}\text { This well will also help } \\
\text { determine the southern } \\
\text { extent of the Local } \\
\text { Aquifer. Historical well } \\
\text { logs indicate that the } \\
\text { Local Aquifer is not } \\
\text { present south of SGZ at } \\
\text { SA3-11-3. This location } \\
\text { is between SGZ and } \\
\text { SA3-11-3. }\end{array}$ \\
\hline \multirow[t]{2}{*}{ E7 Well Pad } & Local & $\begin{array}{l}\text { Determine the presence or } \\
\text { absence of the Local Aquifer. }\end{array}$ & $\begin{array}{l}\text { 1) If the Local Aquifer is present, then } \\
\text { water elevations will help determine } \\
\text { flow directions. } \\
\text { 2) If the Local Aquifer is present but } \\
\text { discontinuous with a higher clay } \\
\text { content, water levels may not be } \\
\text { indicative of the better developed Local } \\
\text { Aquifer to the north. }\end{array}$ & \\
\hline & Alluvial & $\begin{array}{l}\text { Determine interactions between } \\
\text { Alluvial and Local aquifers. }\end{array}$ & & \\
\hline
\end{tabular}


This page intentionally left blank 


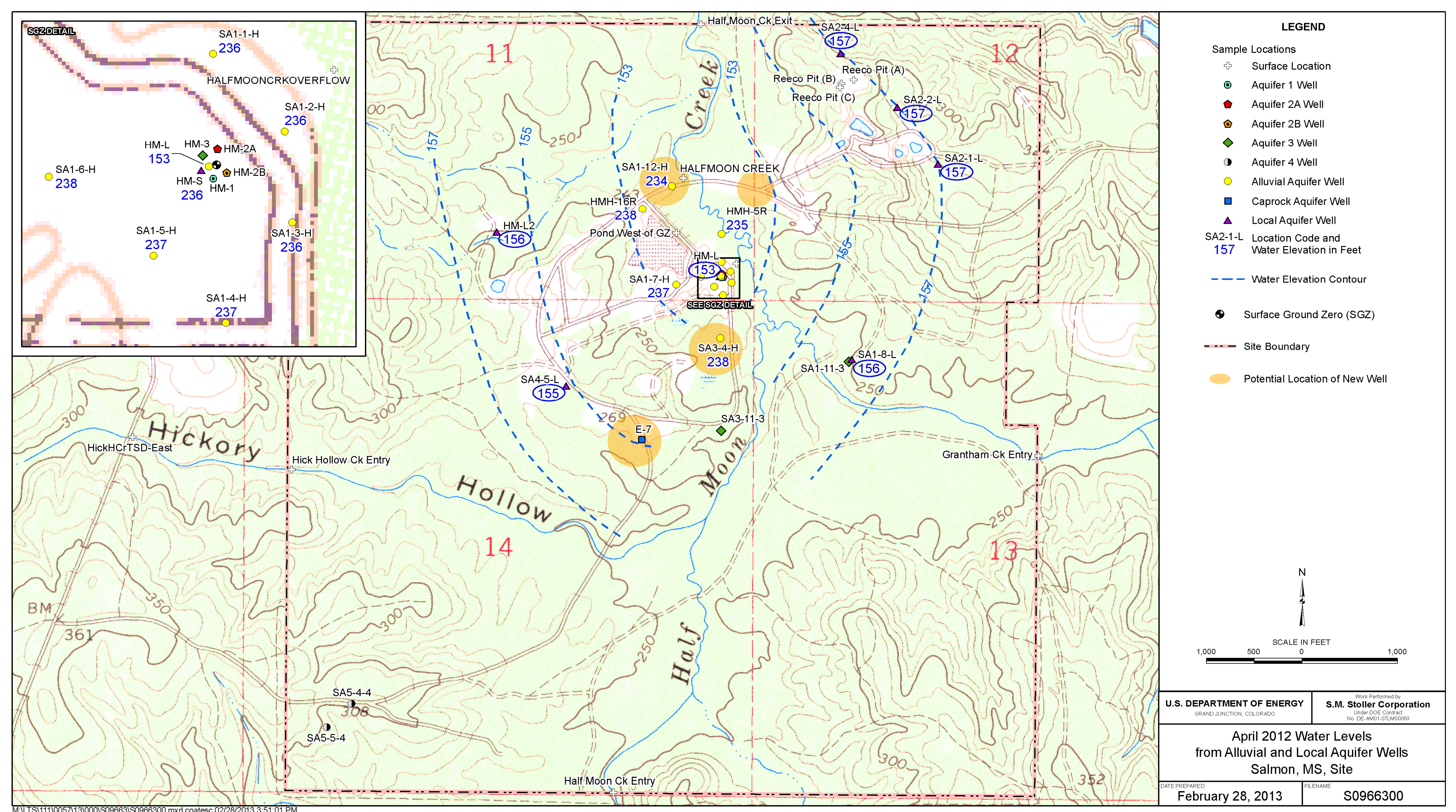

Figure 36. Potential Locations for New Wells 
This page intentionally left blank 


\subsection{References}

Bowen, S.M., D.L. Finnegan, J.L. Thompson, C.M. Miller, P.L. Baca, L.F. Olivas, and C.G. Geoffrion (Los Alamos National Laboratory); D.K. Smith, W. Goishe, B.K. Esser, J.W. Meadows, N. Namboodiri, and J.F. Wild (Lawrence Livermore National Laboratory), 2001. Nevada Test Site Radionuclide Inventory, 1951-1992, LA-13859-MS, prepared for the U.S. Department of Energy, National Nuclear Security Administration, Nevada Operations Office, Las Vegas, Nevada, September.

DOE (U.S. Department of Energy), 1972. Site Status Report at Decommissioning, NVO-117, Nevada Operations Office, Las Vegas, Nevada, June 30.

DOE (U.S. Department of Energy), 1973. Cleanup Summary Report, Tatum Dome Test Site Mississippi, NVO-129, Nevada Operations Office, Las Vegas, Nevada, June.

DOE (U.S. Department of Energy), 1993. Remedial Investigation and Feasibility Study of the Tatum Dome Test Site Lamar County, Mississippi, Volume 1, Final Work Plan, Nevada Operations Office, Las Vegas, Nevada, September.

DOE (U.S. Department of Energy), 1999. Salmon Site Remedial Investigation Report, Volume 1, Rev. 1, Nevada Operations Office, Las Vegas, Nevada, September.

Fenske, P. R., and T. M. Humphrey, Jr., 1980. The Tatum Dome Project, Lamar County, Mississippi, NVO-225, prepared for the U.S. Department of Energy Nevada Operations Office, August.

Gardner, M.C., and C.E. Downs, 1971. Evaluation of the Project Dribble Site, Hattiesburg, Mississippi, for Disposition, Including Identification of Restrictions, Part I, prepared for the U.S. Department of Energy Nevada Operations Office, March.

Hakala, W.W., 1970. "Subsidence Caused by and Underground Nuclear Explosion," in Proceedings from Symposium on Engineering with Nuclear Explosives, TID-4500, January 14-16, 1970, Las Vegas, Nevada, pp. 1428-1455, May.

Harvey, E.J., and R.V. Chaffin, 1963. Geology and Hydrology of the Tatum Salt Dome Lamar County, Mississippi, Technical Letter: Dribble-34, U.S. Geological Survey, April 28.

IT Corporation, 1994a. Geophysical Investigation Salmon Site Lamar County, Mississippi, October.

IT Corporation, 1994b. Task Summary for Cone Penetrometer Testing Sounding and Soil and Groundwater Sampling, Salmon Site, Lamar County, Mississippi, October.

IT Corporation, 1996. Work Plan Addendum for the Remedial Investigation and Feasibility Study of the Salmon Site, NV-411, November. 
Rawson, D.E., 1965. Geology and Physical and Chemical Properties of the Site for a Nuclear Explosion in Salt, VUF-3020, Lawrence Radiation Laboratory, University of California, Livermore.

USGS (U.S. Geological Survey), 1971. Geohydrology of Tatum Salt Dome Area, Lamar and Marion County, Miss, VUF-1023, August. 
Appendix A

Select 1993 CPT Results 
This page intentionally left blank 
GENERAL WATER QUALITY DATA BY LOCATION (USEE105) FOR SITE SAL01, Salmon Site

LOCATION: C1-17 <borehole, cone penetrometer>

REPORT DATE: 3/12/2013 11:21 am

\begin{tabular}{|c|c|c|c|c|c|c|c|}
\hline PARAMETER & UNITS & $\begin{array}{l}\text { SAMPLE: } \\
\text { DATE ID }\end{array}$ & $\begin{array}{l}\text { DEPTH. } \\
\text { RANGE }\end{array}$ & RESULT & $\begin{array}{l}\text { QUALIFIERS: } \\
\text { LAB DATA QA }\end{array}$ & $\begin{array}{l}\text { DETECTION } \\
\text { LIMIT }\end{array}$ & $\begin{array}{c}\text { UN- } \\
\text { CERTAINTY }\end{array}$ \\
\hline 1,1,1-Trichloroethane & ug/L & 11/03/1993 N001 & $0.00-0.00$ & 5 & $U$ & 5 & - \\
\hline 1,1,2,2-Tetrachloroethane & ug/L & 11/03/1993 N001 & $0.00-0.00$ & 5 & $U$ & 5 & - \\
\hline 1,1,2-Trichloroethane & ug/L & 11/03/1993 N001 & $0.00-0.00$ & 5 & $U$ & 5 & - \\
\hline 1,1-Dichloroethane & ug/L & 11/03/1993 N001 & $0.00-0.00$ & 5 & $U$ & 5 & - \\
\hline 1,1-Dichloroethene & ug/L & 11/03/1993 N001 & $0.00-0.00$ & 5 & $U$ & 5 & - \\
\hline 1,2-Dichloroethane & ug/L & 11/03/1993 N001 & $0.00-0.00$ & 5 & $U$ & 5 & - \\
\hline Tetrachloroethene & ug/L & 11/03/1993 N001 & $0.00-0.00$ & 5 & $U$ & 5 & - \\
\hline Total 1,2-Dichloroethene & ug/L & 11/03/1993 N001 & $0.00-0.00$ & 16 & & 5 & - \\
\hline Trichloroethene & ug/L & 11/03/1993 N001 & $0.00-0.00$ & 74 & & 5 & - \\
\hline
\end{tabular}


GENERAL WATER QUALITY DATA BY LOCATION (USEE105) FOR SITE SAL01, Salmon Site

LOCATION: C1-18 <borehole, cone penetrometer>

REPORT DATE: 3/12/2013 11:21 am

\begin{tabular}{|c|c|c|c|c|c|c|c|c|}
\hline PARAMETER & UNITS & $\begin{array}{l}\text { SAMPL } \\
\text { DATE }\end{array}$ & E: & $\begin{array}{l}\text { DEPTH. } \\
\text { RANGE }\end{array}$ & RESULT & $\begin{array}{l}\text { QUALIFIERS: } \\
\text { LAB DATA QA }\end{array}$ & $\begin{array}{l}\text { DETECTION } \\
\text { LIMIT }\end{array}$ & $\begin{array}{c}\text { UN- } \\
\text { CERTAINTY }\end{array}$ \\
\hline 1,1,1-Trichloroethane & $\mathrm{ug} / \mathrm{L}$ & $11 / 02 / 1993$ & N001 & $0.00-0.00$ & 5 & $U$ & 5 & - \\
\hline 1,1,2,2-Tetrachloroethane & $\mathrm{ug} / \mathrm{L}$ & $11 / 02 / 1993$ & N001 & $0.00-0.00$ & 5 & $U$ & 5 & - \\
\hline 1,1,2-Trichloroethane & $\mathrm{ug} / \mathrm{L}$ & $11 / 02 / 1993$ & N001 & $0.00-0.00$ & 5 & $U$ & 5 & - \\
\hline 1,1-Dichloroethane & $\mathrm{ug} / \mathrm{L}$ & $11 / 02 / 1993$ & N001 & $0.00-0.00$ & 5 & $U$ & 5 & - \\
\hline 1,1-Dichloroethene & $\mathrm{ug} / \mathrm{L}$ & $11 / 02 / 1993$ & N001 & $0.00-0.00$ & 5 & $U$ & 5 & - \\
\hline 1,2-Dichloroethane & $\mathrm{ug} / \mathrm{L}$ & $11 / 02 / 1993$ & N001 & $0.00-0.00$ & 5 & $\mathrm{U}$ & 5 & - \\
\hline Tetrachloroethene & $\mathrm{ug} / \mathrm{L}$ & $11 / 02 / 1993$ & N001 & $0.00-0.00$ & 5 & $U$ & 5 & - \\
\hline Total 1,2-Dichloroethene & $\mathrm{ug} / \mathrm{L}$ & $11 / 02 / 1993$ & N001 & $0.00-0.00$ & 55 & & 5 & - \\
\hline Trichloroethene & $\mathrm{ug} / \mathrm{L}$ & $11 / 02 / 1993$ & N001 & $0.00-0.00$ & 5 & $\mathrm{U}$ & 5 & - \\
\hline
\end{tabular}


GENERAL WATER QUALITY DATA BY LOCATION (USEE105) FOR SITE SAL01, Salmon Site

LOCATION: C2-27 <borehole, cone penetrometer>

REPORT DATE: 3/12/2013 11:21 am

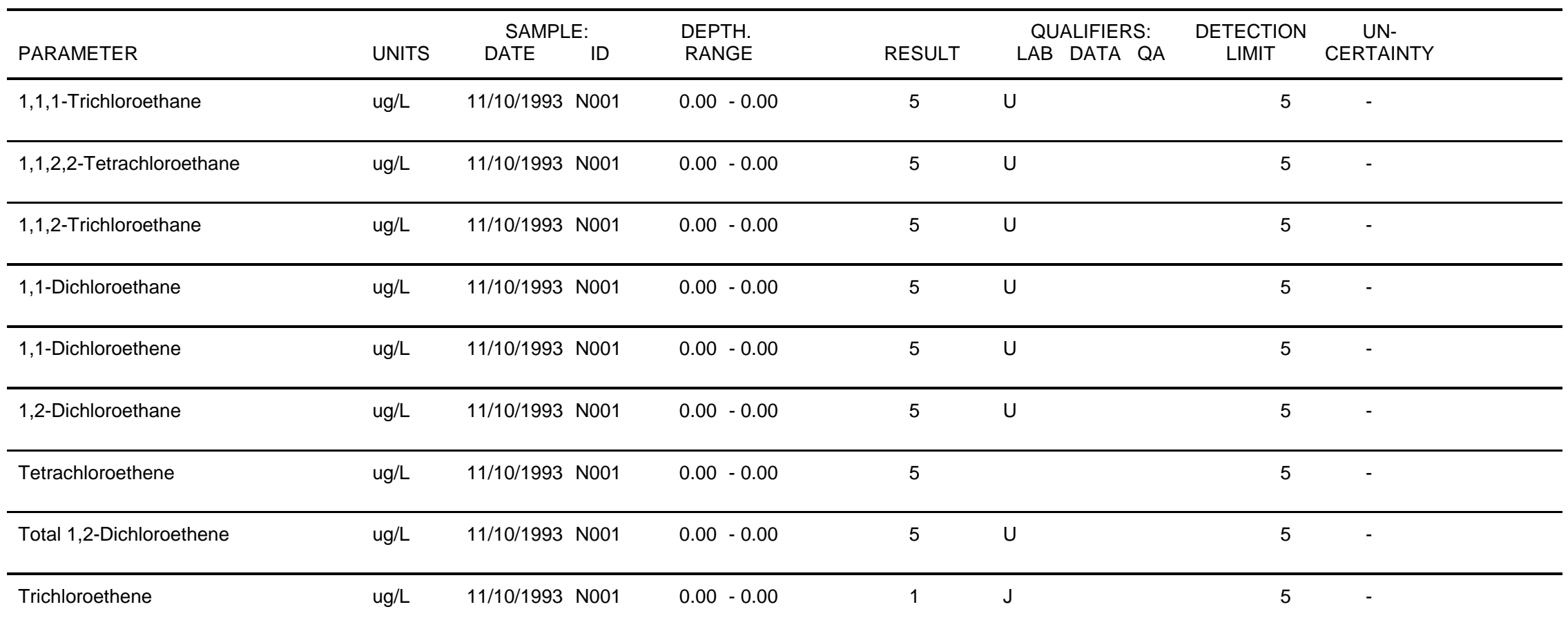


GENERAL WATER QUALITY DATA BY LOCATION (USEE105) FOR SITE SAL01, Salmon Site LOCATION: C2-27 <borehole, cone penetrometer>

REPORT DATE: 3/12/2013 11:21 am

\begin{tabular}{|c|c|c|c|c|c|c|c|}
\hline PARAMETER & UNITS & $\begin{array}{l}\text { SAMPLE: } \\
\text { DATE ID }\end{array}$ & $\begin{array}{l}\text { DEPTH. } \\
\text { RANGE }\end{array}$ & RESULT & $\begin{array}{c}\text { QUALIFIERS: } \\
\text { LAB DATA QA }\end{array}$ & $\begin{array}{l}\text { DETECTION } \\
\text { LIMIT }\end{array}$ & $\begin{array}{c}\text { UN- } \\
\text { CERTAINTY }\end{array}$ \\
\hline
\end{tabular}

RECORDS: SELECTED FROM USEE105 WHERE site_code='SAL01' AND location_code in('C1-17','C1-18','C2-27') AND (data_validation_qualifiers IS NULL OR data_validation_qualifiers NOT LIKE '\%R\%' AND data_validation_qualifiers NOT LIKE '\%X\%') AND cas in('000630-20-6','000071-55-6','000079-34-5','000079-00-5','000075-34-3','000075-35-4','000107-06-2','000156-592','000127-18-4','000540-59-0','000156-60-5','000079-01-6')

SAMPLE ID CODES: $\quad 000 \mathrm{X}=$ Filtered sample. $\quad$ NO0X $=$ Unfiltered sample. $\quad \mathrm{X}=$ replicate number.

\section{LAB QUALIFIERS:}

* Replicate analysis not within control limits.

$+\quad$ Correlation coefficient for MSA < 0.995

$>$ Result above upper detection limit.

A TIC is a suspected aldol-condensation product.

B Inorganic: Result is between the IDL and CRDL. Organic \& Radiochemistry: Analyte also found in method blank.

C Pesticide result confirmed by GC-MS.

D Analyte determined in diluted sample.

E Inorganic: Estimate value because of interference, see case narrative. Organic: Analyte exceeded calibration range of the GC-MS.

H Holding time expired, value suspect.

I Increased detection limit due to required dilution.

$\mathrm{J}$ Estimated

M GFAA duplicate injection precision not met.

N Inorganic or radiochemical: Spike sample recovery not within control limits. Organic: Tentatively identified compund (TIC).

P $>25 \%$ difference in detected pesticide or Aroclor concentrations between 2 columns.

$S$ Result determined by method of standard addition (MSA).

U Analytical result below detection limit.

W Post-digestion spike outside control limits while sample absorbance $<50 \%$ of analytical spike absorbance.

$X \quad$ Laboratory defined (USEPA CLP organic) qualifier, see case narrative.

$Y$ Laboratory defined (USEPA CLP organic) qualifier, see case narrative.

Z Laboratory defined (USEPA CLP organic) qualifier, see case narrative.

DATA QUALIFIERS:

F Low flow sampling method used.

L Less than 3 bore volumes purged prior to sampling.

R Unusable result.
G Possible grout contamination, $\mathrm{pH}>9$.

Presumptive evidence that analyte is present. The analyte is "tentatively identified".

Parameter analyzed for but was not detected.
Estimated value.

Q Qualitative result due to sampling technique

$X \quad$ Location is undefined.

QA QUALIFIER: \# = validated according to Quality Assurance guidelines. 
SOIL CHEMISTRY DATA BY LOCATION (USEE500) FOR SITE SAL01, Salmon Site

LOCATION: C1-17 <borehole>

REPORT DATE: 3/12/2013 11:17 am

\begin{tabular}{|c|c|c|c|c|c|c|c|c|c|c|}
\hline PARAMETER & UNITS & $\begin{array}{l}\text { SAMPL } \\
\text { DATE }\end{array}$ & LE: & $\begin{array}{l}\text { ELEV. RANGE } \\
(\mathrm{FT})\end{array}$ & $\begin{array}{l}\text { DIGEST. } \\
\text { CODE }\end{array}$ & $\begin{array}{l}\text { SAMP } \\
\text { DESC. }\end{array}$ & RESULT & $\begin{array}{l}\text { QUALIFIERS: } \\
\text { LAB DATA QA }\end{array}$ & $\begin{array}{l}\text { DETECTION } \\
\text { LIMIT }\end{array}$ & $\begin{array}{c}\text { UN- } \\
\text { CERTAINTY }\end{array}$ \\
\hline 1,1,1-Trichloroethane & $\mathrm{mg} / \mathrm{kg}$ & $11 / 01 / 1993$ & 0001 & $-9999--9999$ & & & 0.005 & U & 0.005 & - \\
\hline 1,1,2,2-Tetrachloroethane & $\mathrm{mg} / \mathrm{kg}$ & $11 / 01 / 1993$ & 0001 & $-9999--9999$ & & & 0.005 & $\mathrm{U}$ & 0.005 & - \\
\hline $1,1,2$-Trichloroethane & $\mathrm{mg} / \mathrm{kg}$ & $11 / 01 / 1993$ & 0001 & $-9999--9999$ & & & 0.005 & U & 0.005 & - \\
\hline 1,1-Dichloroethane & $\mathrm{mg} / \mathrm{kg}$ & $11 / 01 / 1993$ & 0001 & $-9999--9999$ & & & 0.005 & U & 0.005 & - \\
\hline 1,1-Dichloroethene & $\mathrm{mg} / \mathrm{kg}$ & $11 / 01 / 1993$ & 0001 & $-9999--9999$ & & & 0.005 & $U$ & 0.005 & - \\
\hline 1,2-Dichloroethane & $\mathrm{mg} / \mathrm{kg}$ & $11 / 01 / 1993$ & 0001 & $-9999--9999$ & & & 0.005 & U & 0.005 & - \\
\hline Total 1,2-Dichloroethene & $\mathrm{mg} / \mathrm{kg}$ & $11 / 01 / 1993$ & 0001 & $-9999--9999$ & & & 0.005 & $U$ & 0.005 & - \\
\hline Trichloroethene & $\mathrm{mg} / \mathrm{kg}$ & $11 / 01 / 1993$ & 0001 & $-9999--9999$ & & & 0.006 & & 0.005 & - \\
\hline
\end{tabular}


SOIL CHEMISTRY DATA BY LOCATION (USEE500) FOR SITE SAL01, Salmon Site

LOCATION: C1-17 <borehole>

REPORT DATE: 3/12/2013 11:17 am

\begin{tabular}{|c|c|c|c|c|c|c|c|c|c|}
\hline & & SAMPLE: & ELEV. RANGE & DIGEST. & SAMP & & QUALIFIERS: & DETECTION & UN- \\
\hline PARAMETER & UNITS & DATE & $(\mathrm{FT})$ & CODE & DESC. & RESULT & LAB DATA QA & LIMIT & CERTAINTY \\
\hline
\end{tabular}

RECORDS: SELECTED FROM USEE500 WHERE site_code='SAL01' AND location_code in('C1-17') AND (data_validation_qualifiers IS NULL OR data_validation qualifiers NOT LIKE '\%R\%' AND data validation qualifiers NOT LIKE '\%X\%') AND cas in('000630-20-6','000071-55-6', '000079-34-5', '000079-00-5','000075-34-3', '000075-35-4', '000107-06-2', '000156-59-2' '000540-590 ','000156-60-5','000079-01-6')

\section{DIGESTION CODES:}

SAMPLE DESCRIPTORS (UNIFIED SOIL CLASSIFICATION SYSTEM):

\section{LAB QUALIFIERS:}

* Replicate analysis not within control limits.

$+\quad$ Correlation coefficient for MSA $<0.995$.

$>$ Result above upper detection limit.

A TIC is a suspected aldol-condensation product.

B Inorganic: Result is between the IDL and CRDL. Organic \& Radiochemistry: Analyte also found in method blank.

C Pesticide result confirmed by GC-MS.

D Analyte determined in diluted sample.

E Inorganic: Estimate value because of interference, see case narrative. Organic: Analyte exceeded calibration range of the GC-MS.

H Holding time expired, value suspect.

Increased detection limit due to required dilution.

J Estimated

M GFAA duplicate injection precision not met.

$\mathrm{N}$ Inorganic or radiochemical: Spike sample recovery not within control limits. Organic: Tentatively identified compund (TIC).

P $>25 \%$ difference in detected pesticide or Aroclor concentrations between 2 columns.

S Result determined by method of standard addition (MSA)

$\mathrm{U}$ Analytical result below detection limit.

W Post-digestion spike outside control limits while sample absorbance $<50 \%$ of analytical spike absorbance.

$X$ Laboratory defined (USEPA CLP organic) qualifier, see case narrative.

$Y$ Laboratory defined (USEPA CLP organic) qualifier, see case narrative.

$Z$ Laboratory defined (USEPA CLP organic) qualifier, see case narrative.

\section{DATA QUALIFIERS:}

$F$ Low flow sampling method used.

L Less than 3 bore volumes purged prior to sampling.

$\mathrm{R}$ Unusable result.

G Possible grout contamination, $\mathrm{pH}>9$.

$\mathrm{N}$ Presumptive evidence that analyte is present. The analyte is "tentatively identified".

U Parameter analyzed for but was not detected.
$J$ Estimated value.

Qualitative result due to sampling technique

$X$ Location is undefined

QA QUALIFIER: \# = validated according to Quality Assurance guidelines 